\title{
Seasonal changes in Diel cycling of dissolved iron species in a coal mine drainage impacted creek
}

Daniel B. Harris

West Virginia University

Follow this and additional works at: https://researchrepository.wvu.edu/etd

\section{Recommended Citation}

Harris, Daniel B., "Seasonal changes in Diel cycling of dissolved iron species in a coal mine drainage impacted creek" (2008). Graduate Theses, Dissertations, and Problem Reports. 4379.

https://researchrepository.wvu.edu/etd/4379

This Thesis is protected by copyright and/or related rights. It has been brought to you by the The Research Repository @ WVU with permission from the rights-holder(s). You are free to use this Thesis in any way that is permitted by the copyright and related rights legislation that applies to your use. For other uses you must obtain permission from the rights-holder(s) directly, unless additional rights are indicated by a Creative Commons license in the record and/ or on the work itself. This Thesis has been accepted for inclusion in WVU Graduate Theses, Dissertations, and Problem Reports collection by an authorized administrator of The Research Repository @ WVU. For more information, please contact researchrepository@mail.wvu.edu. 


\title{
Seasonal Changes in Diel Cycling of Dissolved Iron Species in a Coal Mine Drainage Impacted Creek
}

\author{
Daniel B. Harris \\ Thesis submitted to the Eberly College of Arts and Sciences \\ at West Virginia University \\ in partial fulfillment of the requirements for the degree of:
}

Master of Science

in

Geology

\author{
Dorothy Vesper, Ph.D., Chair \\ Joe Donovan, Ph.D. \\ Henry Rauch, Ph.D. \\ Department of Geology and Geography
}

Morgantown, WV

2008

Keywords: geology, geochemistry, diel, daily, cycles, iron, Fe, acid mine drainage 


\section{ABSTRACT \\ Seasonal Changes in Diel Cycling of Dissolved Iron Species in a Coal Mine Drainage Impacted Creek}

\section{Daniel B. Harris}

Diel fluctuations of $\mathrm{pH}$, specific conductance and $\mathrm{Fe}$ species have been documented in Dillan Creek, a small coal mine-impacted tributary to Deckers Creek, WV. Samples were collected hourly over 16-20 hour periods and analyzed for dissolved Fe(II) and dissolved total Fe using a Hach DR2800 spectrophotometer. Fe(II) concentrations increased during the day and decreased at night during late winter sampling. Sampling conducted in the summer shows an opposite trend with $\mathrm{Fe}(\mathrm{II})$ increasing at night and decreasing during the day. Discrepancies between timing of cycles indicate a seasonal variation of controlling mechanisms. In winter, iron cycles are likely controlled by photoreduction reactions dependent on solar cycles. In summer, increased bacterial activity likely causes cycling of iron through daily Fe(II) oxidation and nightly Fe(III) reduction. Iron cycles in Dillan Creek may also be affected by mixing ratio changes induced by evapotranspiration driven water level fluctuations in groundwater. 


\section{Acknowledgements}

I would like to thank the faculty at WVU for granting me the chance to further my education and grow as a geologist. Thanks go specifically to Dorothy Vesper; Ph.D., Joe Donovan; Ph.D., and Henry Rauch; Ph.D. for their guidance in and out of the classroom. Without their help, I would never have come so far with my research. I would also like to thank Jim Luzier for access to his property and the U.S. Department of Interior Office of Surface Mining and the National Mine Land Reclamation Center at West Virginia University for their financial support. Thanks also go to Pam Harris for continuing to be my wife and to my parents for their support. 


\section{Table of Contents}

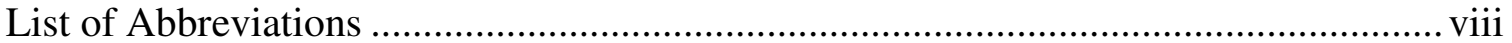

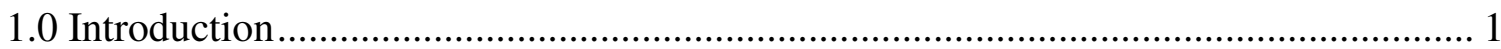

2.0 Rationale and objectives ................................................................................. 2

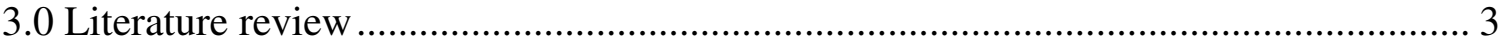

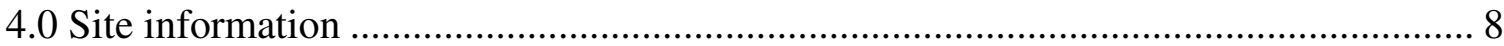

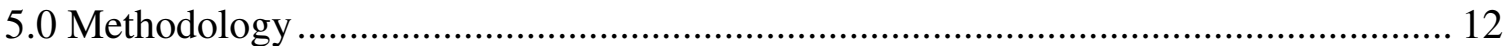

5.1 Measurement of hydraulic parameters ..................................................... 12

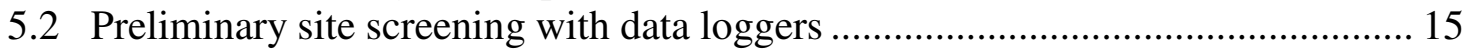

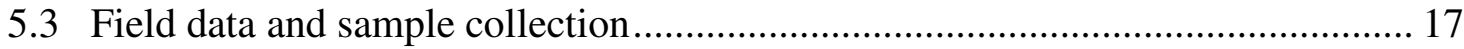

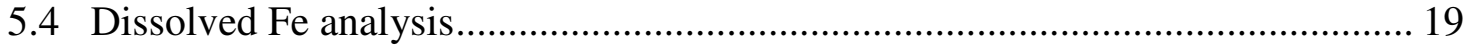

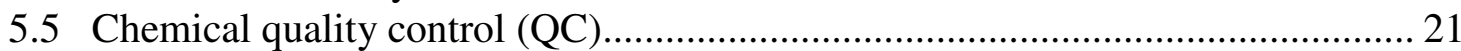

5.6 Sunlight influence diel collection .............................................................. 22

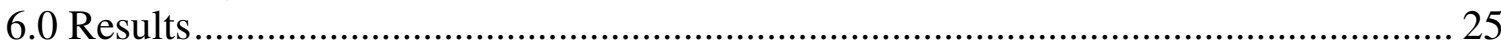

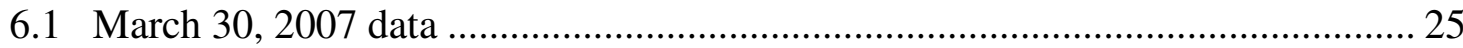

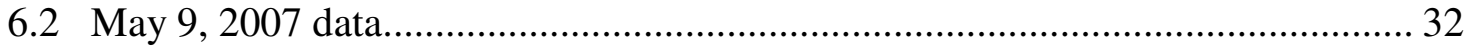

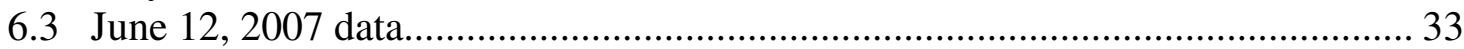

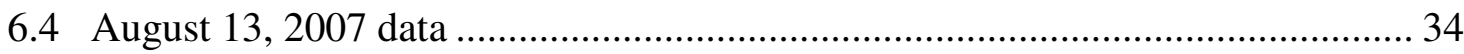

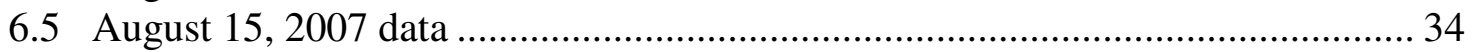

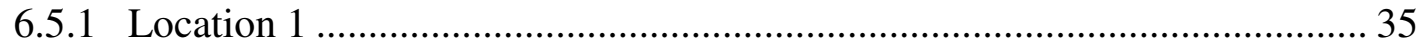

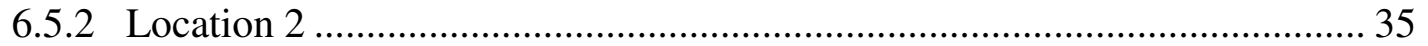

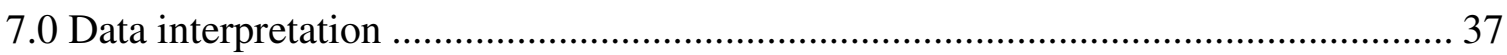

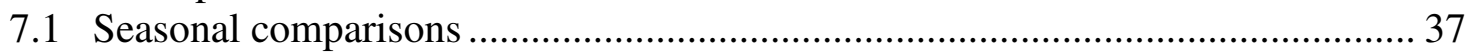

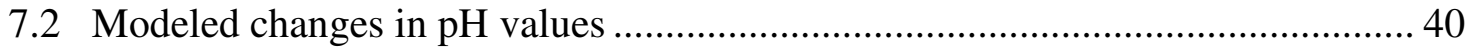

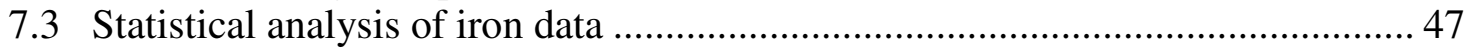

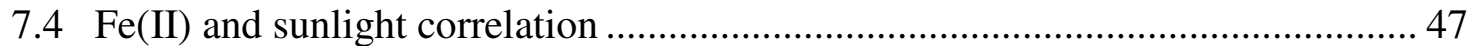

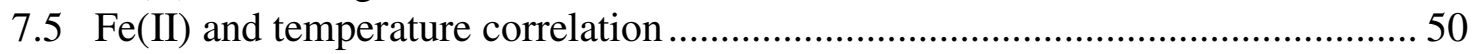

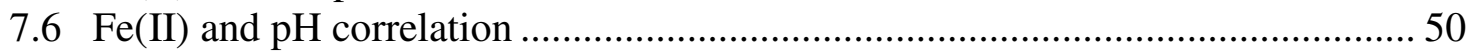

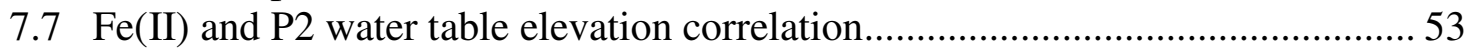

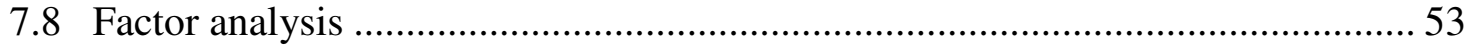

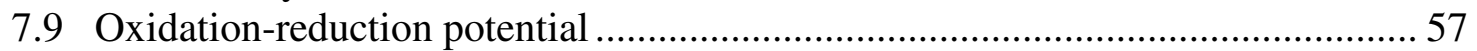

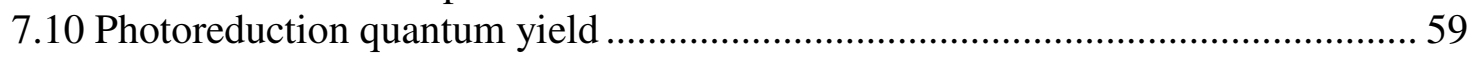

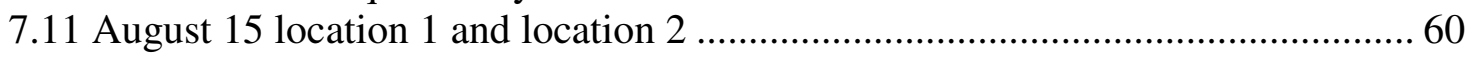

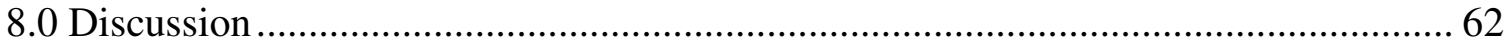

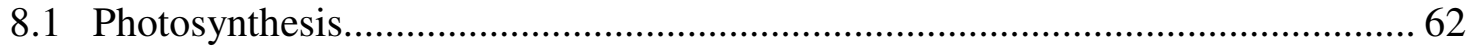

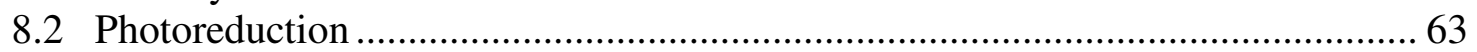

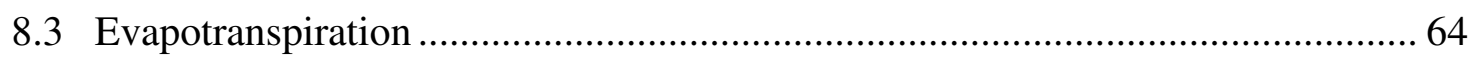

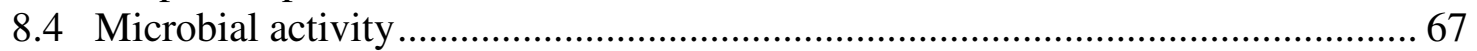

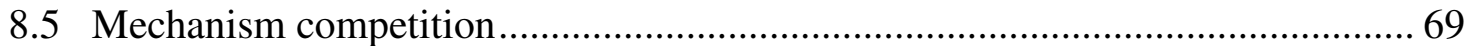

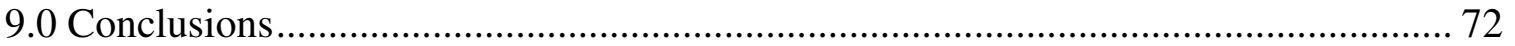

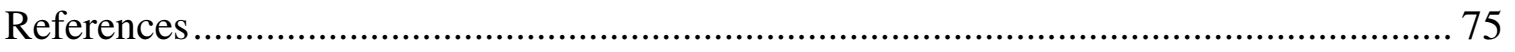

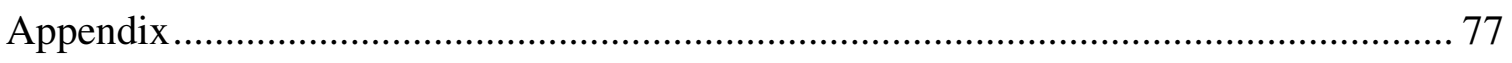




\section{List of Tables}

Table 3-1: Reactions responsible for photoreduction of $\mathrm{Fe}(\mathrm{III})$ to $\mathrm{Fe}(\mathrm{II})$....................... 5

Table 5-1: Mixtures of solutions used to determine Fe(II) and total dissolved Fe

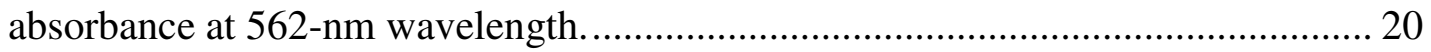

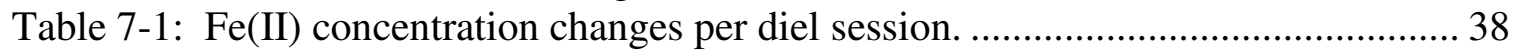

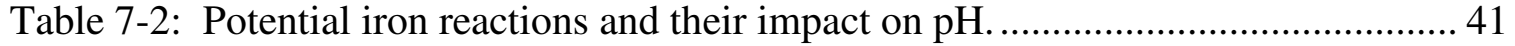

Table 7-3: Critical R-squared values used for assessment of $\mathrm{pH}$ model ........................ 46

Table 7-4: Critical R-squared values based on $\mathrm{n}$ pairs of observations for 0.01 and

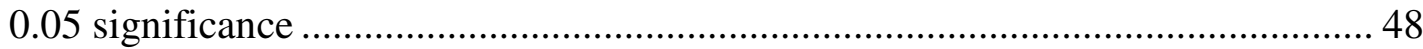




\section{List of Figures}

Figure 3-1: Diel cycles in total Fe, Fe(II) and Fe(III) from outflow waters from a sphagnum peat with limestone and fertilizer wetland in Greenville, KY ................. 6

Figure 4-1: Section of Dillan Creek under study, Masontown, WV .............................. 9

Figure 4-2: Stratigraphic column depicting geologic setting of Dillan Creek................. 10

Figure 4-3: Evapotranspirational pumping mechanism............................................. 11

Figure 5-1: Cross sectional view of referencing scheme for piezometer array. .............. 13

Figure 5-2: Schematic for piezometer construction................................................. 14

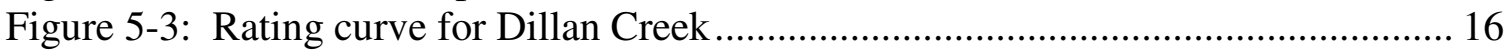

Figure 5-4: Timing and hydrologic setting of diel sampling sessions........................... 18

Figure 5-5: Sunlight intensity difference between location 1 and location 2 on

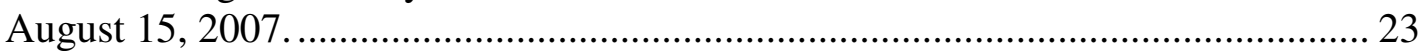

Figure 5-6: Field configuration for sample collection on August 15, 2007................... 24

Figure 6-1: Vegetation differences at Dillan Creek depending on season...................... 26

Figure 6-2: Seasonal pH variation in Dillan Creek, 2007.......................................... 27

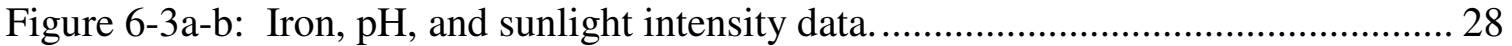

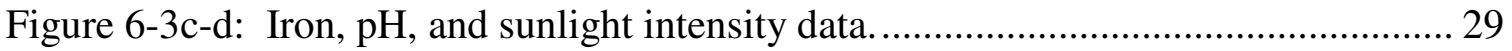

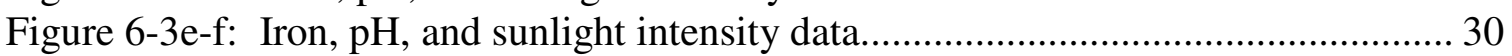

Figure 6-4: Water table elevation changes in Dillan Creek and in the riparian zone

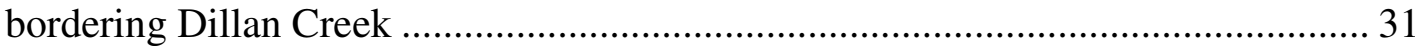

Figure 7-1: Fe(II) concentrations plotted as percent of mean..................................... 39

Figure 7-2: Method used for modeling of $\mathrm{pH}$ fluctuation due to changes in $\mathrm{Fe}(\mathrm{II})$

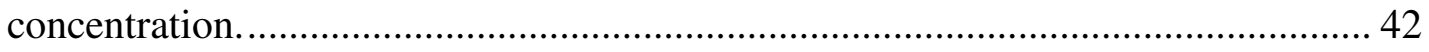

Figure 7-3: Actual pH fluctuations seen in Dillan Creek compared to modeled

values of $\mathrm{pH}$ according to $\mathrm{Fe}$ speciation controls ................................................ 43

Figure 7-4: Correlations for actual $\mathrm{pH}$ and modeled $\mathrm{pH}$ values. .................................. 44

Figure 7-5: $\mathrm{Fe}(\mathrm{II})$ and sunlight intensity correlations, 2007..................................... 49

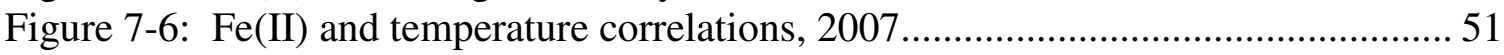

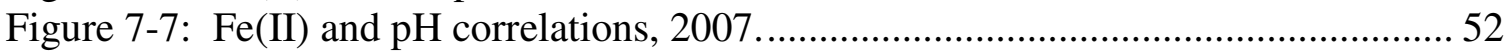

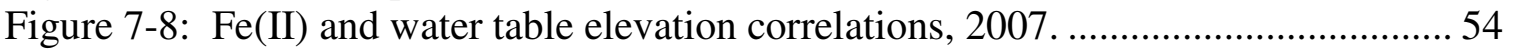

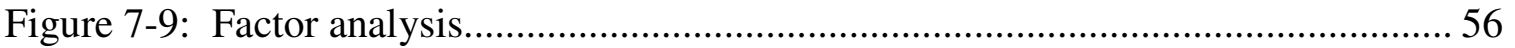

Figure 7-10: Redox conditions for Dillan Creek. ..................................................... 58

Figure 8-1: Diel cycles in dissolved Fe(II) seen in St. Kevin Gulch, CO compared to data from Dillan Creek on March 30, 2007 ....................................................... 65

Figure 8-2: Comparison of Fe(II) data from Dillan Creek to Fe(II) data from a

Sphagnum peat wetland in Greenville, KY..................................................... 70

Figure 9-1: March 30 diel Fe(II) cycle compared to June 12 diel Fe(II) cycle. .............. 73 


\section{List of Appendices}

Table A-1: Data from Dillan Creek, March 30, 2007................................................ 78

Table A-2: Data from Dillan Creek, May 9, 2007 ........................................................ 79

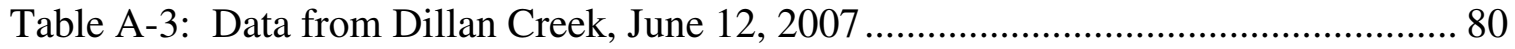

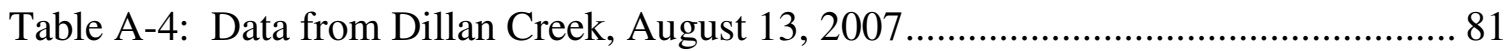

Table A-5: Data from location 1, Dillan Creek, August 15, 2007 .................................. 82

Table A-6: Data from location 2, Dillan Creek, August 15, 2007 ................................. 83

Table A-7: QC samples for Dillan Creek, March 30 and May 9, 2007 ........................... 84

Table A-8: QC samples for Dillan Creek, June 12 and August 13, 2007 ....................... 85

Table A-9: QC samples for Dillan Creek, August 15, 2007 ....................................... 86

Table A-10: Factor analysis for variables from March 30, 2007 ……............................ 87

Table A-11: Factor analysis for variables from May 9, 2007 ......................................... 88

Table A-12: Factor analysis for variables from June 12, 2007 ...................................... 89

Table A-13: Factor analysis for variables from August 13, 2007 .................................... 90

Table A-14: Redox iron reactions and log Ksp values ................................................. 91 


\title{
List of Abbreviations
}

\author{
AMD - Acid Mine Drainage \\ AML - Abandoned Mine Lands \\ DI - Deionized Water \\ DO - Dissolved Oxygen \\ DTW - Depth-to-Water \\ ET - Evapotranspiration \\ HFO - Hydrous Fe Oxides \\ ICP - Inductively Coupled Plasma \\ ICP-MS - Inductively Coupled Plasma - Mass Spectrometry \\ NRCCE - National Research Center for Coal and Energy \\ P1 - Piezometer 1 \\ P2 - Piezometer 2 \\ PC - Creek piezometer \\ PCA - Partial Component Analysis \\ PMF - Proton Motive Force \\ QC - Quality Control \\ SMRCA - Surface Mining Control and Reclamation Act \\ USGS - United States Geological Survey \\ WVU - West Virginia University
}




\subsection{Introduction}

The Surface Mining Control and Reclamation Act (SMCRA) passed in 1977 set standards for the cleanup and maintenance of abandoned mine lands (AMLs) (CFR, 1977). Since then, much work has been done to better understand contamination from AMLs. Water quality from these AMLs is commonly assessed through collection of periodic samples. These are collected daily, annually, or quarterly and are considered to be representative of the overall quality of the water body, despite infrequency of collection. While it is understood that daily fluctuations in temperature, $\mathrm{pH}$ and dissolved oxygen occur, fluctuations in other constituents, particularly of metal concentrations, are less often studied. There has been recent work on the fluctuations of metal concentrations over 24-hour cycles, and several authors have shown that the concentrations of some trace metals may vary by as much as $500 \%$ over that period (Brick and Moore, 1996; Gammons et al., 2005b; Nimick et al., 2003).

Studies on diel cycling of metal concentrations in streams document several controlling mechanisms including photoreduction of Fe(III) (McKnight et al., 2001), biological reduction of Fe(III) (Wieder, 1994), pH controlled sorption (Bourg et al., 2000; Brick and Moore, 1996; Nimick et al., 2003), and precipitation of Mn and Fe oxides (Nimick et al., 2003). Some of these reactions are controlled by direct photocatalytic reactions within the stream while others are coupled to solar influence on photosynthesis and respiration. There has also been work considering the influence of a pumping system driven by evapotranspiration in the riparian zone as a controlling factor for diel metal concentration changes (Brick and Moore, 1996). It has been suggested that evapotranspiration causes daily fluctuation of hydraulic parameters such as stage and turbidity (Roberts and Wilch, 2005), so it is likely to influence other parameters such as metal concentrations. If chemistry of groundwater is significantly different from chemistry of channel water, it is possible that changes in the mixing of the two can cause significant changes in chemical concentrations over short time periods. 


\subsection{Rationale and objectives}

The overall objective of this study was to determine the presence of and to better understand the mechanisms controlling diel fluctuation of metals seen in surface water affected by mine-water contamination. In order to address this goal, four specific questions were considered:

1: Do diel cycles exist for iron species in Dillan Creek?

2: Do diel cycles persist in the absence of sunlight in Dillan Creek?

3: Does evapotranspiration in the meadow surrounding Dillan Creek influence the chemistry of Dillan Creek?

4: Is there a seasonal variation in diel cycles for iron species in Dillan Creek? 


\subsection{Literature review}

Coal mine drainage can be a serious environmental problem through the discharge of elevated levels of potentially toxic dissolved constituents. Specifically, acid mine drainage (AMD) is a condition where mine released constituents cause a decrease in $\mathrm{pH}$, commonly associated with high concentrations of $\mathrm{Fe}, \mathrm{Al}, \mathrm{Mn}$ and $\mathrm{SO}_{4}$, (Rose and Cravotta, 1998). The primary source for these constituents and $\mathrm{pH}$ effects is the dissolution of pyrite $\left(\mathrm{FeS}_{2}\right)$ in the presence of an oxidant and water. Recently, it has been discovered that repeatable, 24-hour (diel) fluctuations in these constituents are likely, although the causes of these cycles depend on climate, geologic setting and microbial impact.

Cycles in $\mathrm{pH}$ are commonly explained as an indirect product of cycles in sunlight intensity. Diel behavior in plant photosynthetic processes dependent on sunlight may lead to a diel signal in $\mathrm{pH}$ via the consumption and release of carbon dioxide (Nimick et al., 2003). It has also been shown that abiotic processes such as hydrolysis of $\mathrm{Al}^{3+}$ or $\mathrm{Fe}(\mathrm{III})$ producing acidity, and dissolution of hydroxides producing alkalinity, may control diel fluctuation of $\mathrm{pH}$ (Wieder, 1994). Metals with solubilities dependent on $\mathrm{pH}$ are likely to show variation coincident with these $\mathrm{pH}$ cycles (Brick and Moore, 1996; McKnight et al., 2001; Nimick et al., 2003; Wieder, 1994), although others have suggested that temperature-driven sorption may influence cycling of metal concentrations more than $\mathrm{pH}$ (Gammons et al., 2005b).

Adsorption reactions may explain diel cycling of some elements. Increases in $\mathrm{pH}$ can lead to an increase in cation adsorption and decreases in $\mathrm{pH}$ can lead to an increase in anion adsorption in near-neutral $\mathrm{pH}$ regimes (Nimick et al., 2003). This has been interpreted as a change in surface charge of hydrous metal oxides due to deprotonation or protonation when $\mathrm{pH}$ increases or decreases respectively. If cycles in metal concentrations are driven by surface charge induced sorption cycles, an opposite cycle should be witnessed for cationic and anionic species. This trend has been observed in streams in Montana and Idaho where cycles of the cations $\mathrm{Cd}, \mathrm{Mn}$ and $\mathrm{Zn}$ showed the opposite diel cycle as the As oxyanion (Nimick et al., 2003). Timing of diel trends in 
these ions and $\mathrm{pH}$ from a neutral to alkaline stream in Prickly Pear Creek, MT have also been shown to be consistent year round with little variation seasonally (Nimick et al., 2005).

Several studies have documented the importance of photoreduction as a controlling mechanism for Fe species fluctuations (Gammons et al., 2005a; McKnight et al., 1988; McKnight et al., 2001; Nimick et al., 2003; Wieder, 1994). The rate at which photoreduction can occur is very rapid for hydroxide and dicarboxylate complexes, with half lives ranging from $0.2-5.0$ minutes for dicarboxylates and 20 minutes for $\mathrm{Fe}(\mathrm{OH})^{2+}$ (Helz et al., 1994). According to this half life data, production of Fe(II) through photoreduction should be easily observable over the time scale of a diel session. It has been shown that photoreduction of Fe(III) through reactions shown in Table 3.1 can provide a rapid increase in $\mathrm{Fe}$ (II) in surface, atmospheric and oceanic waters. This series of reactions shows the process by which solar radiation can induce the movement of an electron from a ligand orbital to a $\mathrm{Fe}$ (III) orbital, thus creating Fe(II). The rate at which this process occurs varies by ligand, but can be very rapid for hydroxide ions or dicarboxylates (Helz et al., 1994).

Direct photoreduction results in an increase in dissolved Fe(II) concentration and a decrease in dissolved Fe(III) concentration as sunlight intensity increases. In the evening, a decrease in sunlight intensity leads to a decrease in dissolved $\mathrm{Fe}(\mathrm{II})$ and an increase in dissolved $\mathrm{Fe}(\mathrm{III})$. Potential changes in dissolved Fe species concentrations associated with photoreduction are commonly modeled using a "quantum yield" (McKnight et al., 1988) approach by which the maximum possible amount of $\mathrm{Fe}(\mathrm{II})$ created through $\mathrm{Fe}$ (III) photoreduction at any measured sunlight intensity can be estimated (Gammons et al., 2005a; McKnight et al., 1988; McKnight et al., 2001; Wieder, 1994).

Nightly increases in $\mathrm{Fe}(\mathrm{II})$ may be a function of bacterially-mediated anaerobic $\mathrm{Fe}$ (III) reduction and anoxic $\mathrm{FeS}_{2}$ oxidation, while the daytime decreases in $\mathrm{Fe}$ (II) may be caused by decreased anaerobic bacterial influence due to oxygenation of water by photosynthesis (Figure 3-1) (Wieder, 1994). These trends have been documented in the outflows of constructed wetlands designed for treatment of mine drainage with $\mathrm{pH}$ values lower than 6 . In wetlands where $\mathrm{pH}$ approached 6 and in flask incubation studies with 
Table 3-1: Reactions responsible for photoreduction of Fe(III) to Fe(II) (Helz et al., 1994).

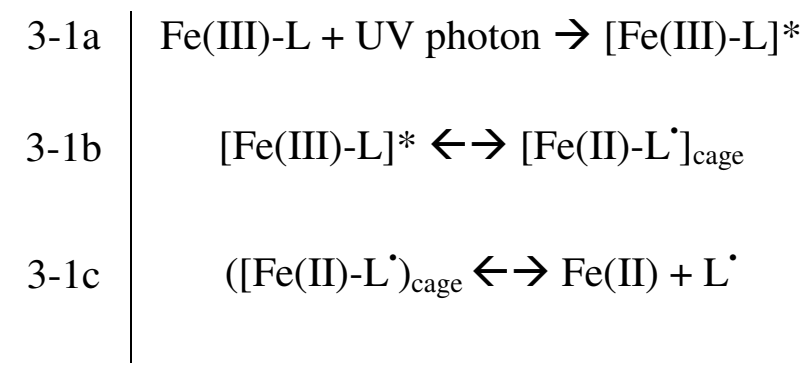

The subscript cage refers to a cage structure, $*$ refers to a

free radical, $\mathrm{L}$ refers to a ligand, and ${ }^{\bullet}$ refers to a free electron. 


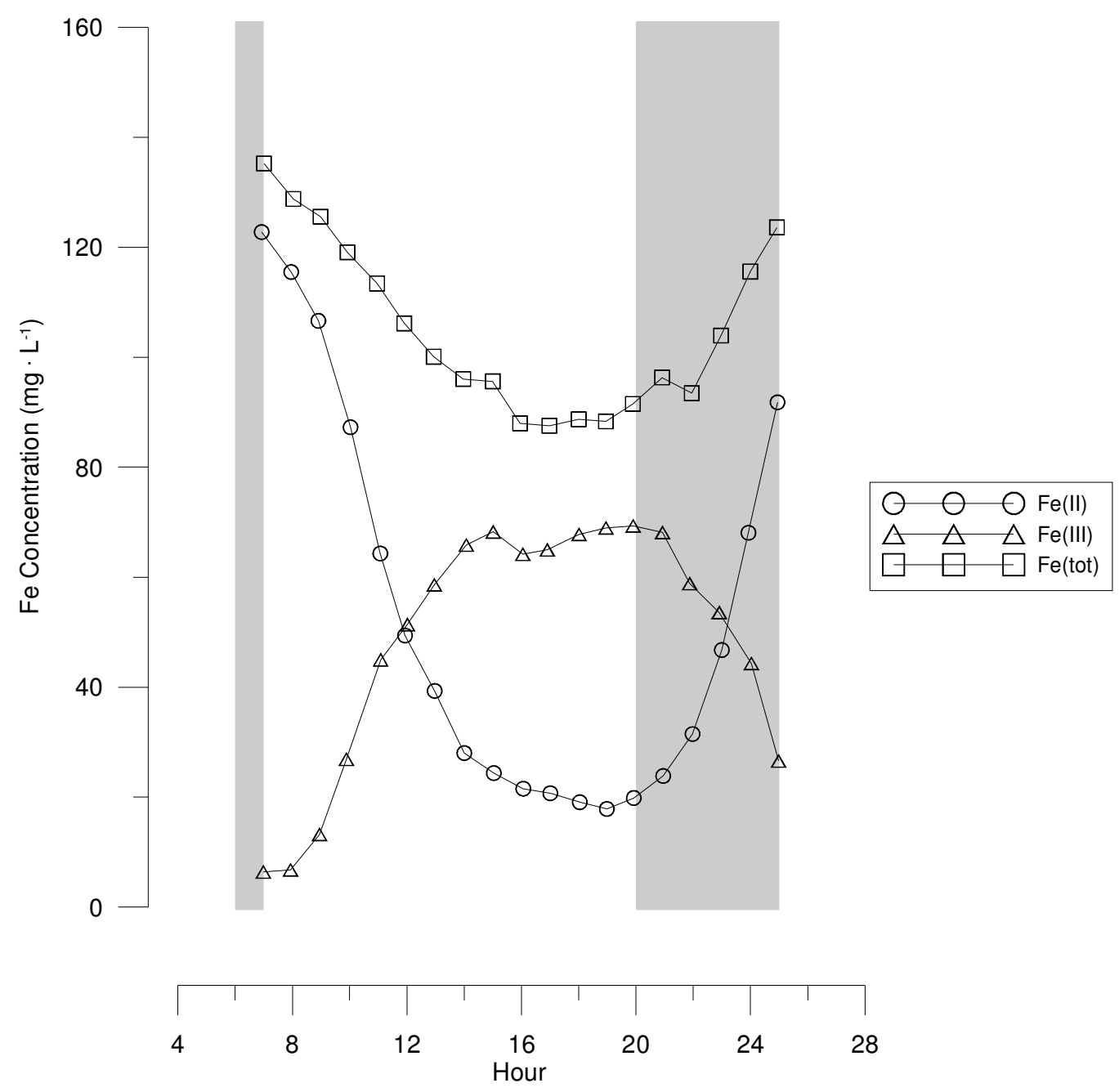

Figure 3-1: Diel cycles in total $\mathrm{Fe}, \mathrm{Fe}(\mathrm{II})$ and $\mathrm{Fe}(\mathrm{III})$ from outflow waters from a sphagnum peat with limestone and fertilizer wetland in Greenville, KY. Modified from Wieder (1994). 
$\mathrm{pH}$ values of 6 or higher, Fe(III) reduction was insignificant (Wieder, 1994). The trends observed in these cycles also show a decrease in $\mathrm{pH}$ during the day, precisely opposite to what would be expected if photoreduction reactions or photosynthesis dominated the system. The $\mathrm{pH}$ changes in constructed wetlands were attributed to the combination of both $\mathrm{Fe}(\mathrm{III})$ reduction $\left(\mathrm{H}^{+}\right.$consuming $)$and $\mathrm{FeS}_{2}$ oxidation $\left(\mathrm{H}^{+}\right.$producing $)$or some other acidity generating mechanism (Wieder, 1994). Other studies provide evidence for both biologically mediated oxidation and reduction of Fe species in aerobic and anaerobic environments (Weber et al., 2006).

Evapotranspiration (ET)-driven pumping of riparian groundwater may also explain diel fluctuation in Fe concentrations. Situations in which groundwater chemistry is substantially different from in-stream chemistry could show a diel signal when ET controls the mixing ratio and rate of flux between the groundwater and the stream (Brick and Moore, 1996; Nimick et al., 2003; Nimick et al., 2005). If increased rates of ET occur during sunlight hours, groundwater elevations should decrease, causing decreased flux into the creek from the groundwater. Rises in the groundwater elevation are associated with periods of decreased ET at night. Potential reversals of gradient may occur during the transition from day to night if groundwater elevation is similar to creek stage. While this mechanism is often cited as possible, geochemical processes commonly have more influence over in-stream chemical cycles than hydraulic exchange processes (Nimick et al., 2005).

Differences in cycles of Fe species indicate differing controlling mechanisms dependent on geochemical and hydrological setting. Increases in Fe(II) during the day are documented in rocky, mountainous streams, while increases in Fe(II) during the night are documented in constructed wetlands with high amounts of biological activity. Trends showing an increase in turbidity and conductivity are in locations with abundant vegetation and evapotranspiration. 


\subsection{Site information}

The Deckers Creek sub-watershed has an area of approximately $166 \mathrm{~km}^{2}$ and is located in the Upper Monongahela watershed in Preston and Monongalia counties (Christ, 2005). Dillan Creek, a small westward-flowing tributary to Deckers Creek, lies within the Deckers Creek sub-watershed, and is located approximately 2.5 kilometers southeast of Masontown, WV (Figure 4-1). At the site, Dillan Creek is underlain by the Conemaugh Group, which lies above the Upper Freeport coal and below the Pittsburgh coal (Figure 4-2). Mines in the Upper Freeport coal have contributed the majority of AMD to the Deckers Creek watershed (Christ, 2003). Strata in this area are on the eastern limb of an anticline, with Greenbrier limestone outcropping at the surface in the core west of Masontown.

The research site is within the upper reaches of Dillan Creek and is heavily impacted by AMD. AMD is received from AMLs which border Dillan Creek on both sides. This drainage drives the $\mathrm{pH}$ from 6 to below 4 and contributes high loads of $\mathrm{Al}, \mathrm{Fe}$ and Mn (Rose and Cravotta, 1998).

At the site, Dillan Creek flows through a flat, grassy meadow (Figure 4-1). The meadow has abundant plant life ranging from tall grasses to large bushes, which may provide the mechanism for summertime evapotranspirational pumping in the riparian zone (Figure 4-3). The meadow is located in a lowland bordered on both sides by large areas of mine spoil, providing contaminated water from both sides of the meadow. The channel depth and riparian depth-to-groundwater is no greater than one meter. During storm events the entire meadow becomes inundated. 


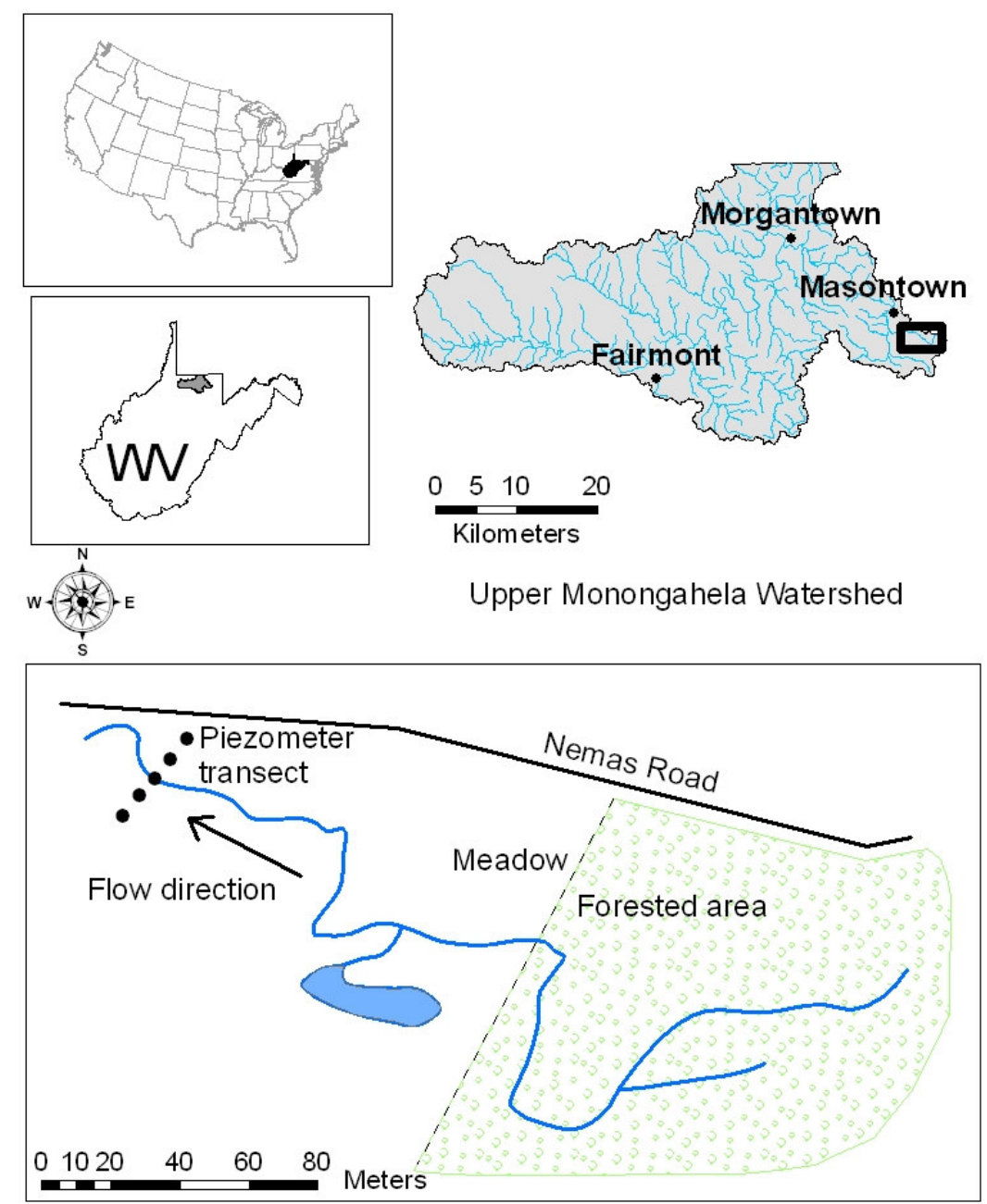

Data from WVU State GIS

Technical Center, 2008

Figure 4-1: Section of Dillan Creek under study, Masontown, WV. Inserts provide regional location relative to US, WV and local watersheds. 


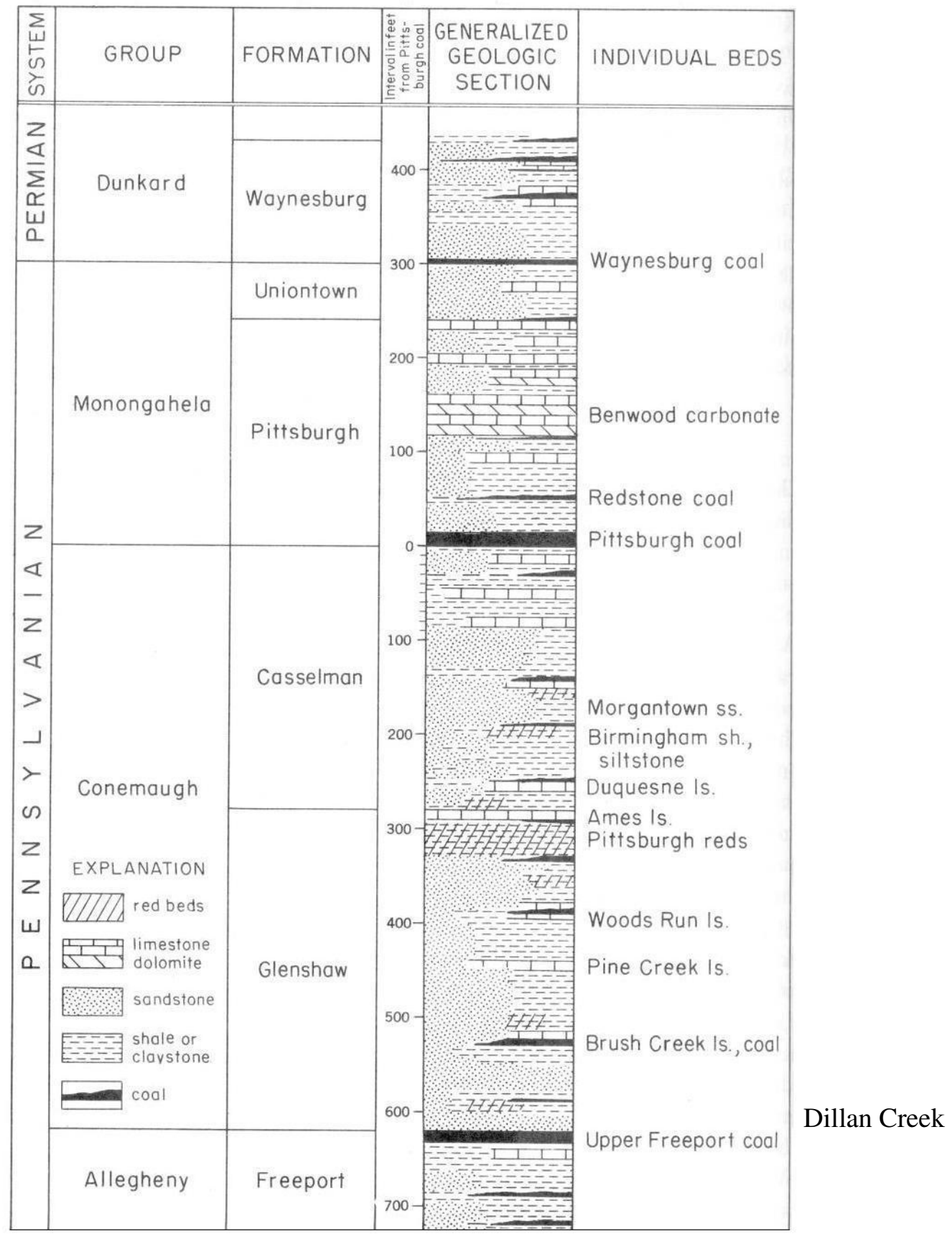

Figure 4-2: Stratigraphic column depicting geologic setting of Dillan Creek. Modified from Wagner et al. (1970) 


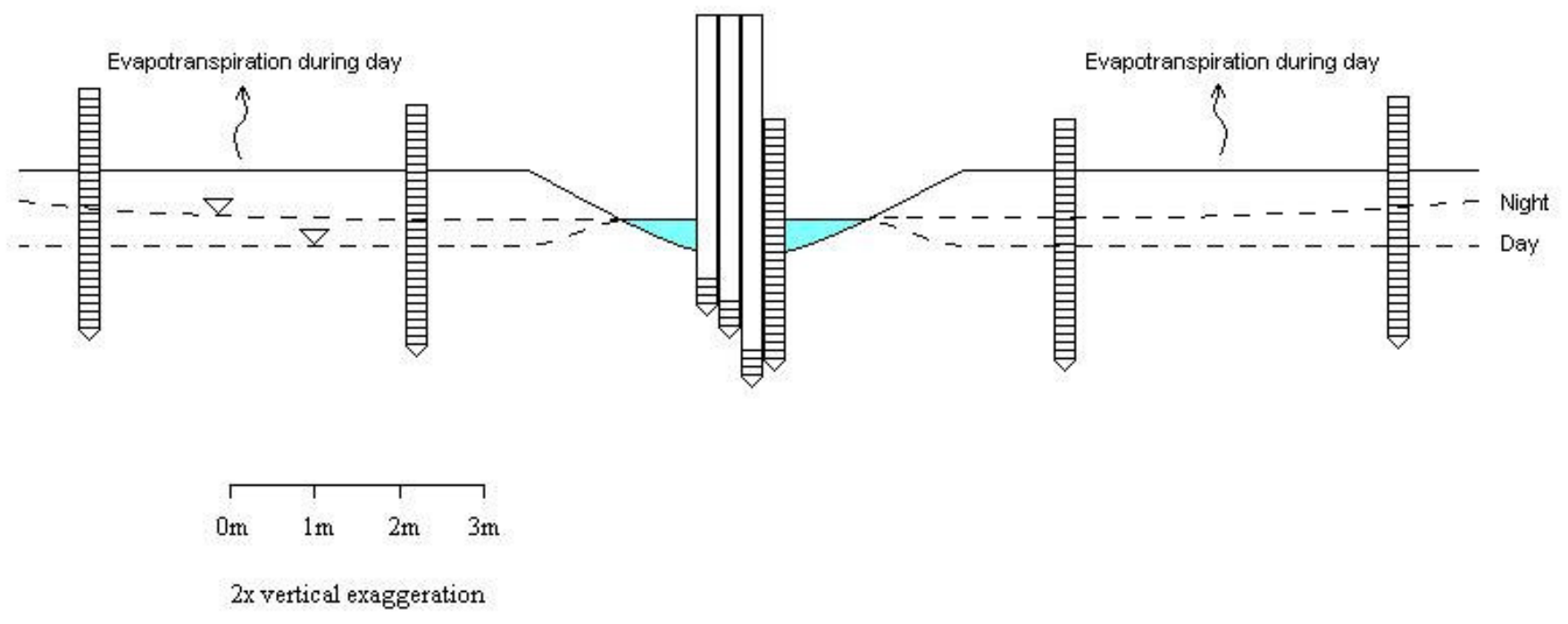

Figure 4-3: Evapotranspirational pumping mechanism. Evapotranspiration during daytime causes the stream to lose water to groundwater. No evapotranspiration at night causes stream to gain water from the groundwater. 


\subsection{Methodology}

\subsection{Measurement of hydraulic parameters}

A cluster of piezometers was driven at Dillan Creek in order to assess groundwater hydrologic conditions. The cluster consisted of eight five-cm diameter piezometers driven in a straight line perpendicular to the creek (Figure 5-1). Two piezometers were driven into the ground on both sides of the creek, and four were driven into the sediment in the channel. Meadow piezometers were spaced with 3.7 meters between piezometers. The four piezometers driven into the creek were all located within a $15-\mathrm{cm}$ radius. Piezometers driven into the meadow were 1.5 meters long and driven to a depth no less than one meter. Each meadow piezometer was continuously slotted to give the elevation of the water table. The piezometers in the creek were at the lengths of $1.68,1.83$ and 2.13 meters and were slotted along the bottom $15 \mathrm{~cm}$ (Figure 5-2). Data collected from these piezometers show a cross-sectional view of the shallow groundwater flow paths. An additional continuously slotted stilling well was driven into the creek so that changes in the stage could be recorded with dataloggers.

During collection episodes, depth-to-water (DTW) was measured using an electronic water-level meter. All data were referenced to an arbitrary elevation of 30.48 meters (100 ft). In order to do this, differences in absolute elevation of each piezometer were measured. Piezometer four was set as the reference elevation since it was the lowest of all the piezometers (Figure 5-1). Height of each other piezometer above piezometer four was then measured using an eye level and a measuring tape. The height of each piezometer above the ground surface was also measured. Water table elevation in the piezometer being corrected was then calculated using the equation:

$$
30.48+\text { C - DTW }
$$

where $\mathrm{C}$ is the difference in elevation between piezometer four and the piezometer being corrected, and DTW is distance from the top of the piezometer to the water table. By 


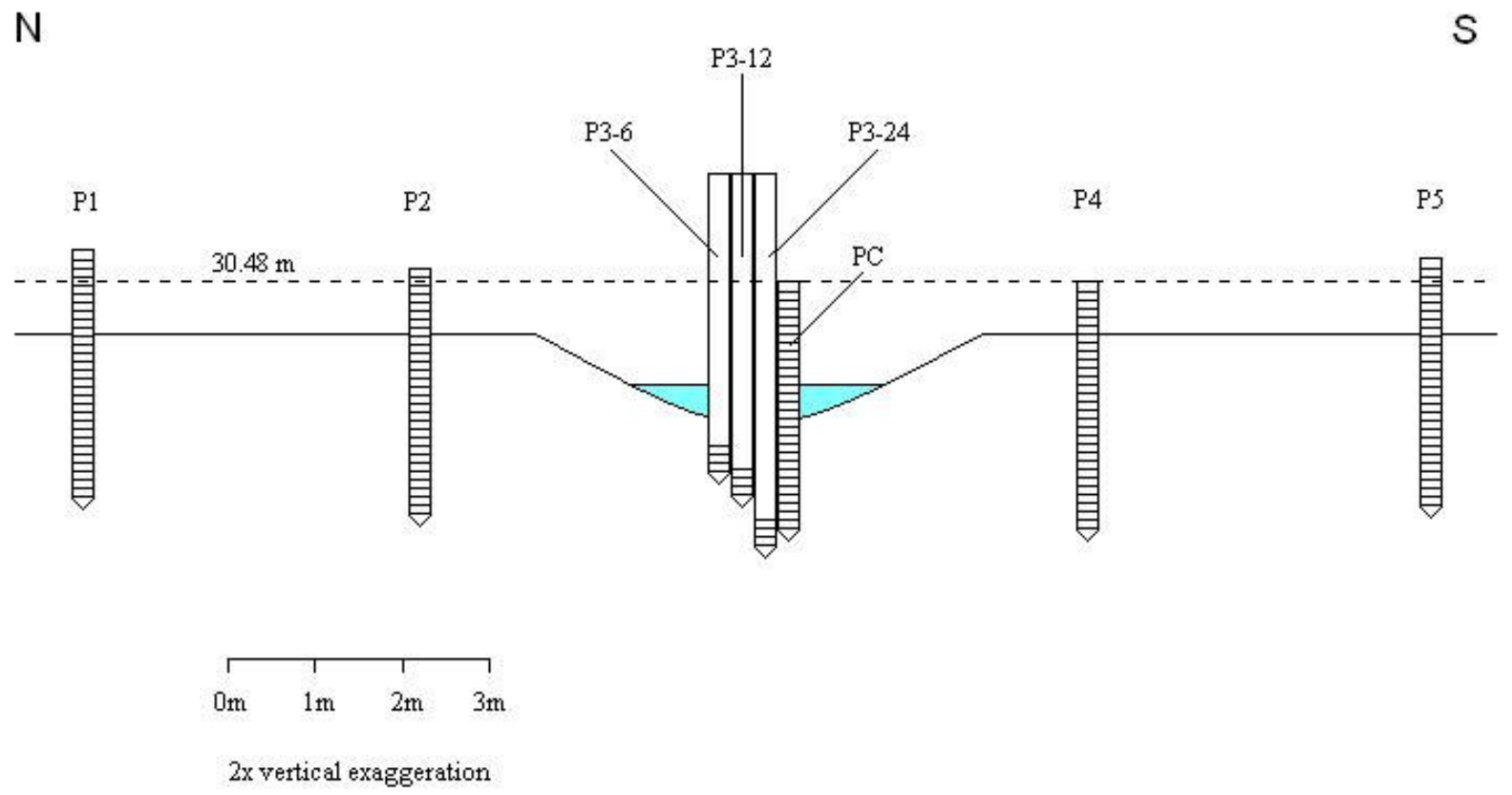

Figure 5-1: Cross sectional view of referencing scheme for piezometer array. 


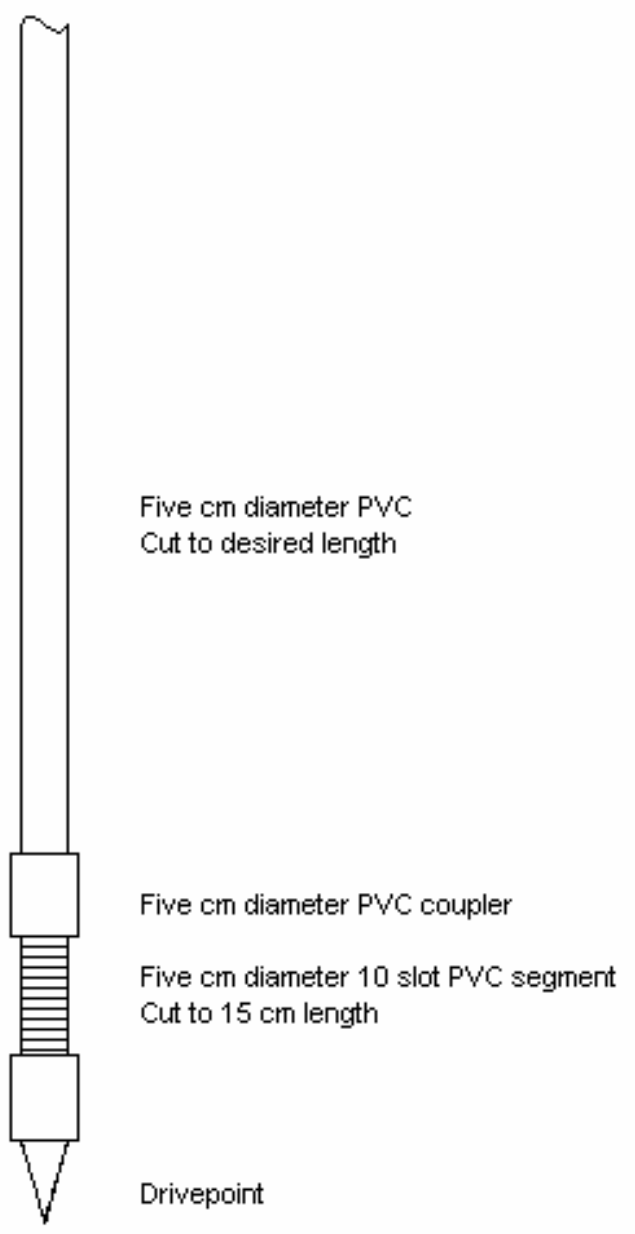

Figure 5-2: Schematic for piezometer construction. 
calculating the water table elevation from the each piezometer at several times during diel collection episodes, it was possible to observe water table fluctuations.

A rating curve was created for Dillan Creek using discharge and stage measurements from a variety of stream conditions lower than bank-full stage (Figure 53). Discharge was measured using a Swoffer ${ }^{\circledR} 3000$ meter, which automatically calculates discharge from a cross-sectional measurement of velocities and depths. For each stage, discharge was measured in triplicate and plotted along a rating curve.

Discharge and stage are expressed as log values and are related through the equation:

$$
\log \mathrm{Q}=\log (\mathrm{a})+(\mathrm{b}) \log (\mathrm{Z})
$$

where $\mathrm{a}$ and $\mathrm{b}$ are defined by stream reach configuration, and $\mathrm{Z}$ refers to stage. The equation of a best fit power function line was used to estimate discharge from a variety of stage measurements within the boundaries of the rating curve at an R-squared value of 0.994. Dillan Creek experiences flooding during high precipitation, however all data collected for this study were collected during low flow conditions at less than bank-full capacity.

Hydrologic results are simplified to show variation between the creek piezometer (PC) and piezometer $2(\mathrm{P} 2)$. Data from piezometer $1(\mathrm{P} 1)$ is suspect due to the likelihood of its positioning in a filled channel. Evidence supporting this claim is related to the abundance of organic deposits such as leaves and grasses discovered during emplacement of the channel. Furthermore, P1 shows more rapid response and recovery from storm events.

\subsection{Preliminary site screening with data loggers}

Continuous logging of $\mathrm{pH}$, temperature, conductivity and stage was performed using a calibrated In-Situ Troll ${ }^{\circledR} 9500$ programmed to collect measurements on tenminute intervals. The $\mathrm{pH}$ probe was calibrated using a 2-point calibration to $\mathrm{pHs}$ of 4 and 7 , the conductivity probe was calibrated using $\mathrm{KCl}$ solution of $1413 \mu \mathrm{S} / \mathrm{cm}$, and the water pressure probe was calibrated by zeroing the unit above water. Sunlight intensity was

measured using $\mathrm{HOBO}^{\circledR}$ loggers hung from tree branches near the Troll ${ }^{\circledR}$. The Troll ${ }^{\circledR}$ 


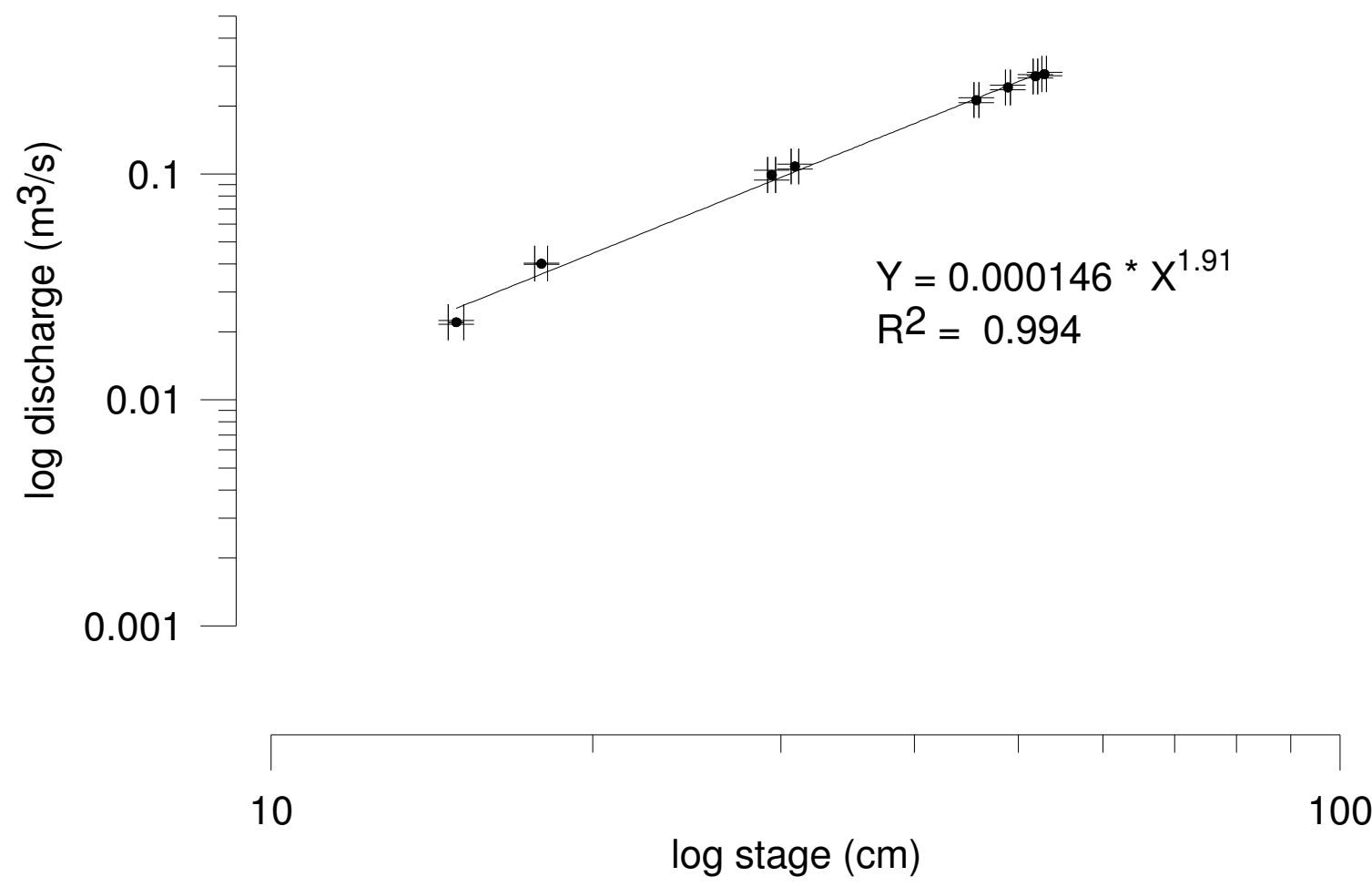

Figure 5-3: Rating curve for Dillan Creek. Error bars show standard deviation calculated from measurements of discharge made in triplicate. Days with only one measurement show standard deviation equal to the maximum seen on any sampling day. 
was either placed inside a two-meter long slotted PVC pipe and left in sunlit portions of Dillan Creek or lowered into piezometers to collect data on groundwater. Collecting periods typically ranged from five to ten days before the data were downloaded for analysis. $\mathrm{HOBO}^{\circledR}$ stowaway tidbits were also used to continuously monitor groundwater temperatures in piezometers.

\subsection{Field data and sample collection}

Each diel sampling session was conducted after several days with no precipitation during low-flow conditions. Low-flow conditions were identified using stage information from the United States Geological Survey (USGS) monitoring station on Deckers Creek (Figure 5-4), located approximately $20 \mathrm{~km}$ downstream from the confluence with Dillan Creek. Dillan Creek recovers from precipitation events much faster than Deckers Creek but the Deckers Creek data illustrate that sampling events were conducted close to low-flow. During each diel sampling session, water level data were collected for each piezometer in order to detect any effects to Dillan Creek potentially caused by groundwater fluctuations. The $\mathrm{pH}$, temperature, conductivity and stage were monitored concurrently with sample collection using the In-Situ Troll ${ }^{\circledR} 9500$ in the same manner as was used for screening data collection. Groundwater temperatures and sunlight intensities were measured using dataloggers. Two $\mathrm{HOBO}^{\circledR}$ water level loggers were also used to measure groundwater pressure changes in P2 and PC during each data collection episode. Piezometer water pressure data were later corrected using barometric pressure data from a third logger.

Samples were collected hourly during 16-20-hour periods as grab samples. During each hour, a grab sample was analyzed in the field for Fe(II) concentrations, and a second sample was collected and stored on ice in a dark cooler for later total Fe analysis at West Virginia University (WVU). Each sample was filtered using a 0.45-micron PVDF filter and a dedicated disposable syringe. Samples collected for analysis at WVU were acidified with $1 \mathrm{~mL}$ of trace metal hydrochloric acid. Grab samples were not acidified. 


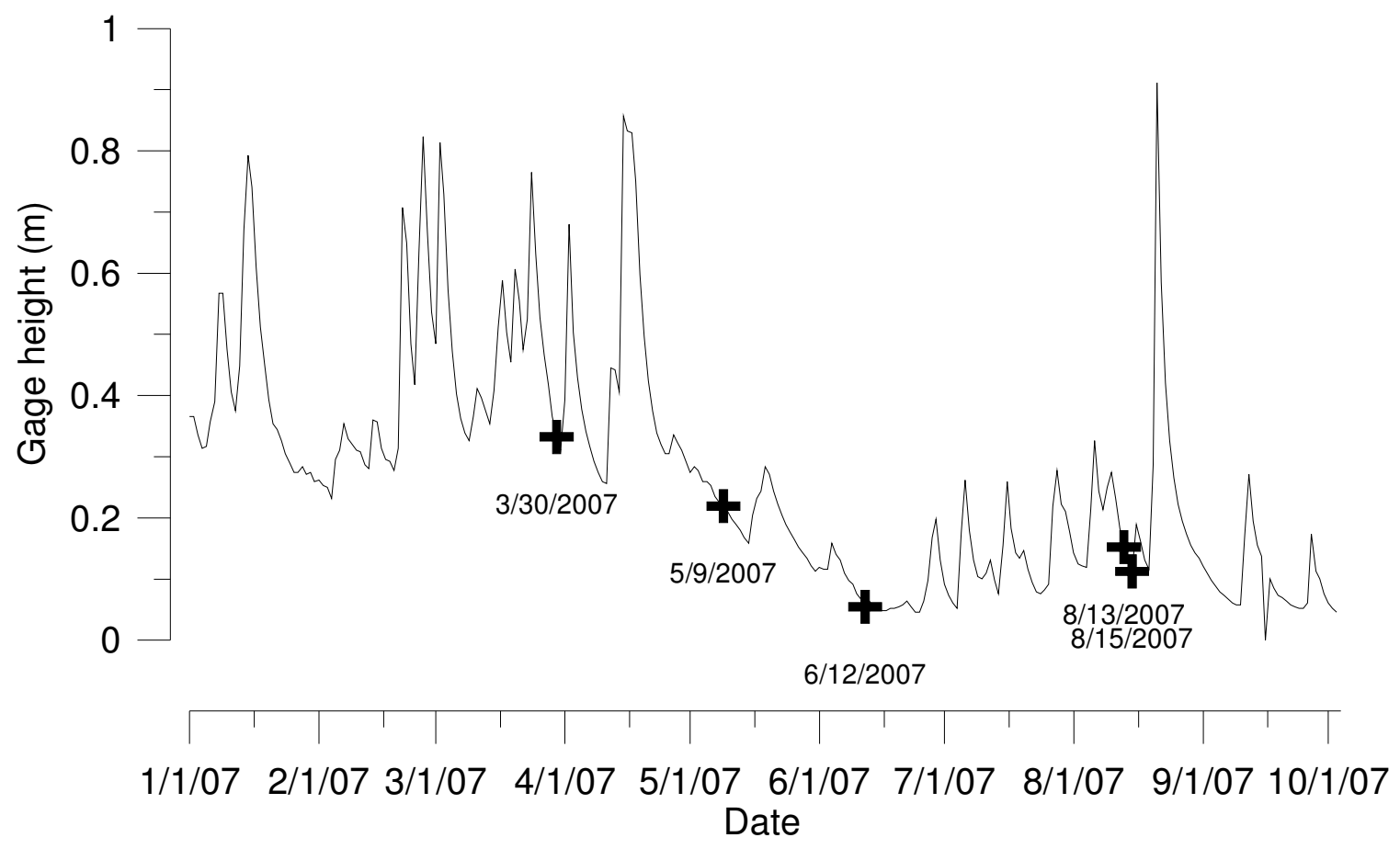

Figure 5-4: Timing and hydrologic setting of diel sampling sessions. Data is from sampling station on Deckers Creek approximately $20 \mathrm{~km}$ downstream from the confluence between Dillan Creek and Deckers Creek. These data approximate the hydrologic setting of Dillan Creek. 


\subsection{Dissolved Fe analysis}

$\mathrm{A} \mathrm{Hach}^{\circledR}$ DR2800 spectrophotometer was used for analysis of dissolved Fe(II) and total dissolved Fe concentrations. Dissolved Fe concentrations in this study refer to all Fe that passes through $0.45 \mu \mathrm{m}$ filters. Analysis of Fe(II) was performed using a ferrozine-HEPES buffer solution as the reactant (Faulkner et al., 1999). Ferrozine reagent, 3-(2-pyridyl)-5,6-bis(4-phenylsulfonic acid)-1,2,4-triazine, monosodium salt, monohydrate, reacts with $\mathrm{Fe}(\mathrm{II})$ to form a purple complex species which is stable in a $\mathrm{pH}$ range of 4 to 9 (Stookey, 1970). HEPES buffer was added to the ferrozine solution in order to stabilize $\mathrm{pH}$ during the reaction. The absorbance of light at a wavelength of 562 $\mathrm{nm}$ when passed through the Fe(II) - ferrozine complex can be measured spectrophotometrically and used to determine Fe(II) concentrations when used in conjunction with prepared calibration curves since absorbance is linear with respect to $\mathrm{Fe}(\mathrm{II})$ concentration with ferrozine as the reagent.

The analysis was conducted by combining set volumes of the sample and the ferrozine-HEPES solution. The ratio of the volumes depended upon the iron concentration in the sample (Table 5-1). Calibration curves were constructed separately for each sample:ferrozine ratio used. This approach was used, rather than sample dilution, to simplify the field analysis.

Total Fe concentrations were determined using ferrozine as the reactant and $0.5 \mathrm{~N}$ hydroxylamine $\mathrm{HCl}$ solution as the reducing agent to convert all $\mathrm{Fe}$ into the $\mathrm{Fe}$ (II) form for measurement (Lovley and Phillips, 1987). The absorbances of the Fe(II) - ferrozine complexes were measured at $562 \mathrm{~nm}$ wavelength (Stookey, 1970) and the corresponding concentrations calculated from calibration curves designed to bracket absorbances. Fe(II) calibration curves were made by diluting a stock solution of $100 \mathrm{mg} \mathrm{L}^{-1} \mathrm{Fe}$ (II) solution made using solid $\mathrm{Fe}\left(\mathrm{NH}_{4}\right)_{2}\left(\mathrm{SO}_{4}\right)_{2} * 6 \mathrm{H}_{2} \mathrm{O}$ and measuring the associated absorbances. Total Fe calibration curves were made by diluting total Fe standard solution to appropriate concentrations and measuring the associated absorbances. Concentration standards were created to bracket sample values. Several calibration curves were necessary since the concentrations of Fe species in Dillan Creek varied seasonally. 
Table 5-1: Mixtures of solutions used to determine Fe(II) and total dissolved Fe absorbance at 562-nm wavelength.

\section{$\mathrm{Fe}(\mathrm{II})$}

\begin{tabular}{ccc}
\hline & $\begin{array}{c}\text { High Fe } \\
\text { concentrations }\end{array}$ & $\begin{array}{c}\text { Low Fe } \\
\text { concentrations }\end{array}$ \\
\hline sample vol. & $2 \mathrm{~mL}$ & $4 \mathrm{~mL}$ \\
*ferrozine vol. & $5 \mathrm{~mL}$ & $5 \mathrm{~mL}$ \\
reaction time & $2 \mathrm{~min}$ & $2 \mathrm{~min}$. \\
\hline
\end{tabular}

Fe total dissolved

\begin{tabular}{ccc}
\hline & High concentrations & Low concentrations \\
\hline sample vol. & $2 \mathrm{~mL}$ & $4 \mathrm{~mL}$ \\
*ferrozine vol. & $5 \mathrm{~mL}$ & $5 \mathrm{~mL}$ \\
$\begin{array}{l}\text { Hydroxylamine } \\
\mathrm{HCl}(0.5 \mathrm{~N}) \text { vol. }\end{array}$ & $2 \mathrm{~mL}$ & $2 \mathrm{~mL}$ \\
reaction time & $2 \mathrm{~min}$ & $2 \mathrm{~min}$.
\end{tabular}

*Ferrozine solution is $1.0 \mathrm{~g} / \mathrm{L}$ solid ferrozine and $11.0 \mathrm{~g} / \mathrm{L}$ HEPES buffer adjusted to $\mathrm{pH} 4-8$ with $\mathrm{NaOH}$. 
Analysis of total Fe was performed in the same manner as was analysis of $\mathrm{Fe}(\mathrm{II})$ where the volume ratio of the ferrozine-HEPES solution and the sample were determined by the total Fe concentration in the sample. Separate calibration curves were constructed for each sample:ferrozine ratio used. Fe(III) concentrations were calculated by subtracting $\mathrm{Fe}(\mathrm{II})$ concentrations from total Fe concentrations. Due to the difference in collection and analysis, some samples indicate less total Fe than Fe(II). When this is the case, calculated values for Fe(III) are negative. Negative values for Fe(III) concentration indicate that $\mathrm{Fe}(\mathrm{III})$ is below detection in this method

\subsection{Chemical quality control $(Q C)$}

QC samples collected included a blank with only deionized water (DI) and reagent grade $\mathrm{HCl}$ (for spectrophotometer analysis) to determine if contamination entered the process through acidification. One duplicate sample was analyzed per ten regular samples in order to assess data precision. A method blank was also analyzed in the field in order to evaluate any contamination that may enter the system through field processes. This sample was DI filtered through a $0.45-\mu \mathrm{m}$ filter using a syringe. The appropriate QC samples were analyzed in the same manner as all other samples.

Accuracy of the spectrophotometer was 0.005 abs at $0.0-0.5$ abs, or $1 \%$ at $0.5-$ 2.0 abs. Duplicate samples yielded an average difference of $0.026 \mathrm{mg} / \mathrm{L}$ for Fe(II) and $\mathrm{Fe}(\mathrm{III})$ concentrations with a maximum difference of $0.122 \mathrm{mg} / \mathrm{L}$ for samples DH-3DiC05 and DH-3-DiC06 collected on 6/12/2007. In terms of absorbance, the average error between duplicate samples was 0.006, which is just outside of the error expected from the meter. Field blank samples yielded an average concentration of $0.004 \mathrm{mg} / \mathrm{L}$ for $\mathrm{Fe}(\mathrm{II})$ and total Fe samples with a maximum blank concentration of $0.051 \mathrm{mg} / \mathrm{L}$ from sample DH-1-DiC11 collected on 3/30/2007. All blank samples show concentrations at least one order of magnitude lower than field samples, and therefore no data was eliminated from this study. 


\subsection{Sunlight influence diel collection}

For the August 15 diel sampling episode, sunlight influences were eliminated through use of a black and white plastic tarp, measuring 30.5 by 3 meters, that was designed to block sunlight and heat. The tarp was placed over Dillan Creek upstream of the piezometer transect using tent stakes in such a way that water contact with plastic was minimal. The white side of the tarp faced upwards in order to reflect light and heat. The tarp eliminated $99 \%$ of the available sunlight to the creek as measured by sunlight dataloggers hung both under the tarp and in the channel outside of the tarp (Figure 5-5). For the sunlight diel sampling episode, two locations were identified for sample collection (Figure 5-6). Location 1 refers to the outflow from the tarp and is used as the site where sunlight influences have been eliminated. Location 2 refers to the inflow point before the water from Dillan Creek goes below the tarp. Location 2 is used as the control point where sunlight influences have not been eliminated. A calibrated In-Situ Troll ${ }^{\circledR}$ was placed at both location 1 and location 2 for continuous data logging of the same parameters described earlier. Grab samples collected at location 1 were collected in a foil wrapped and covered beaker in order to cut out sunlight influences during transport to the field station. All instruments used during the processing of field samples were also covered in foil to decrease sunlight intensity during analysis. 


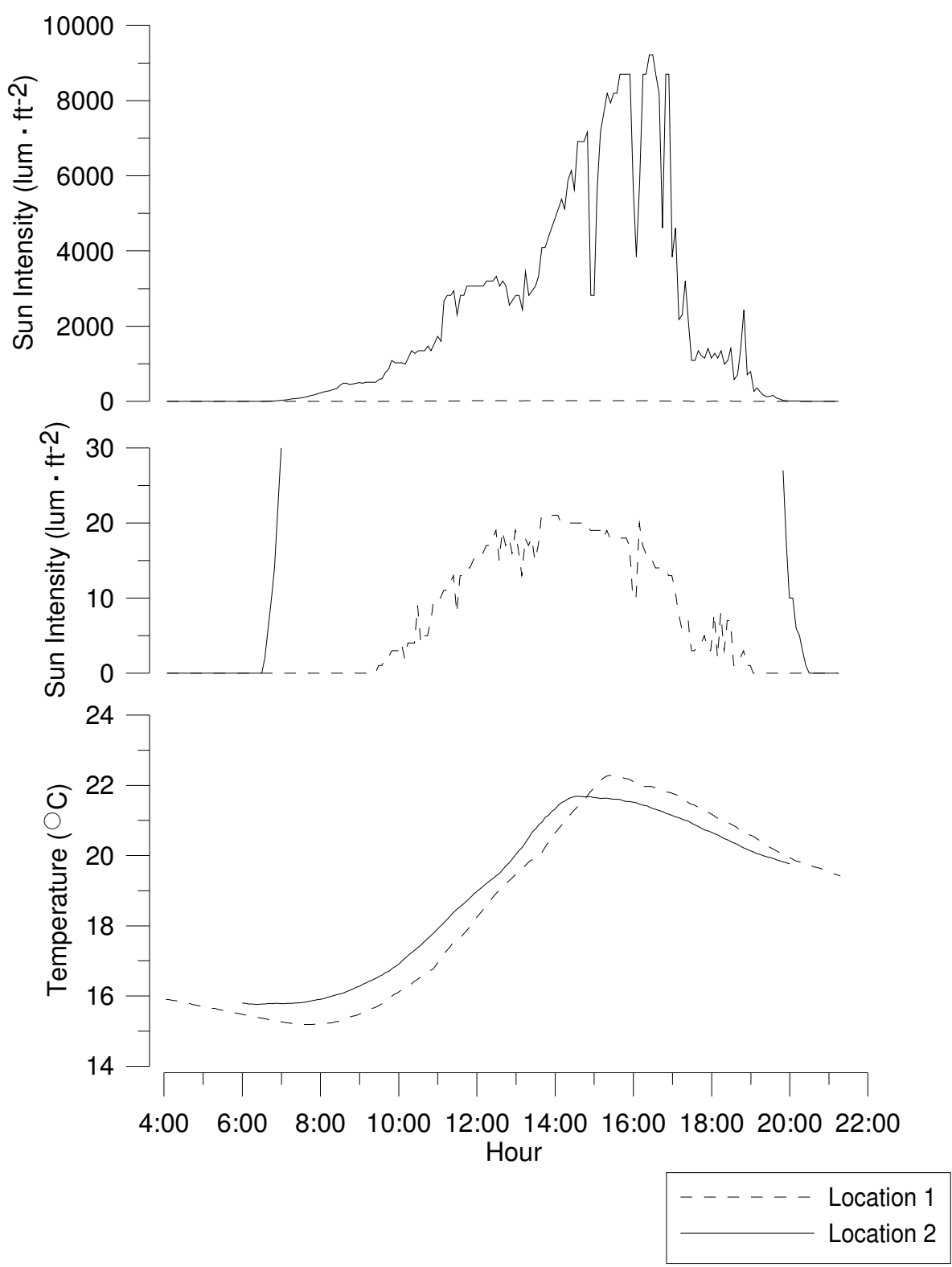

Figure 5-5: Sunlight intensity difference between location 1 and location 2 on August 15, 2007. 


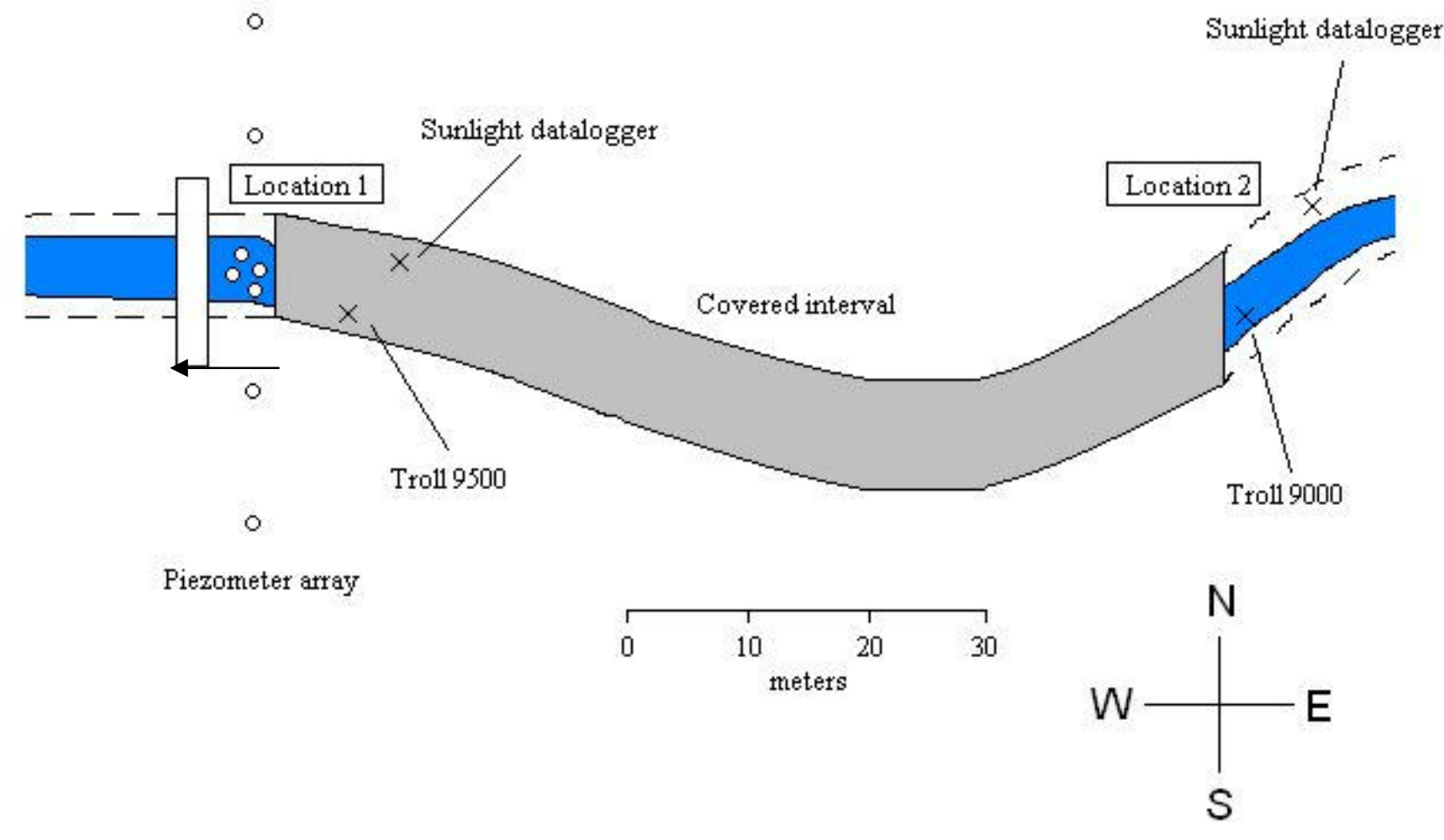

Figure 5-6: Field configuration for sample collection on August 15, 2007. Flow is from east to west. Location 1 is located at the outflow from the sunlight inhibiting tarp. Location 2 is located directly before the sunlight-inhibiting tarp 


\subsection{Results}

\subsection{March 30, 2007 data}

The sampling episode conducted during late winter occurred on March 30, 2007. Despite the lateness in season, snow was still visible on the ground, and plant life was still minimal due to recent thaw (Figure 6-1). Trees and bushes had no leaves yet, and grasses were absent.

Diel magnitude values for $\mathrm{pH}$, water level changes and $\mathrm{Fe}$ concentrations were calculated by dividing the difference in maximum and minimum values by the minimum value. Late winter sampling showed an average $\mathrm{pH}$ value of 4.29 with a variation of $6.7 \%$ from a minimum value of 4.19 (Figure 6-2). Decreases in $\mathrm{pH}$ were witnessed in the evening with a slight increase after sunset.

A diel cycle in iron species was observed during the late winter sampling episode (Figure 6-3a). This cycle showed a sudden increase in Fe(II) at sunrise and continued to increase along with sunlight intensity until it reached a maximum concentration of 0.624 $\mathrm{mg} / \mathrm{L}$ shortly after noon. After this point, Fe(II) concentrations gradually decreased until the end of sampling. Fe(III) concentrations show the exact opposite trend showing a decrease beginning at sunrise and continuing until a concentration beneath the detection limit was reached at 13:00. After 13:00, Fe(III) concentration then increased through the end of sampling. Total Fe concentrations remained roughly constant throughout the entire diel run, but showed a slight increase of $0.109 \mathrm{mg} / \mathrm{L}$ from the beginning of the cycle to the end. This slight increase may be related to the gradual decrease in discharge over the course of the cycling period since the creek stage decreased by $2.5 \mathrm{~cm}$.

The March 30 diel run showed no diel variability in water table elevation (Figure 6-4). There was a steady decline in water table elevation in P2 of $2.1 \mathrm{~cm}$ over the course of the diel run, but it was coincident with a decrease in creek stage of approximately 

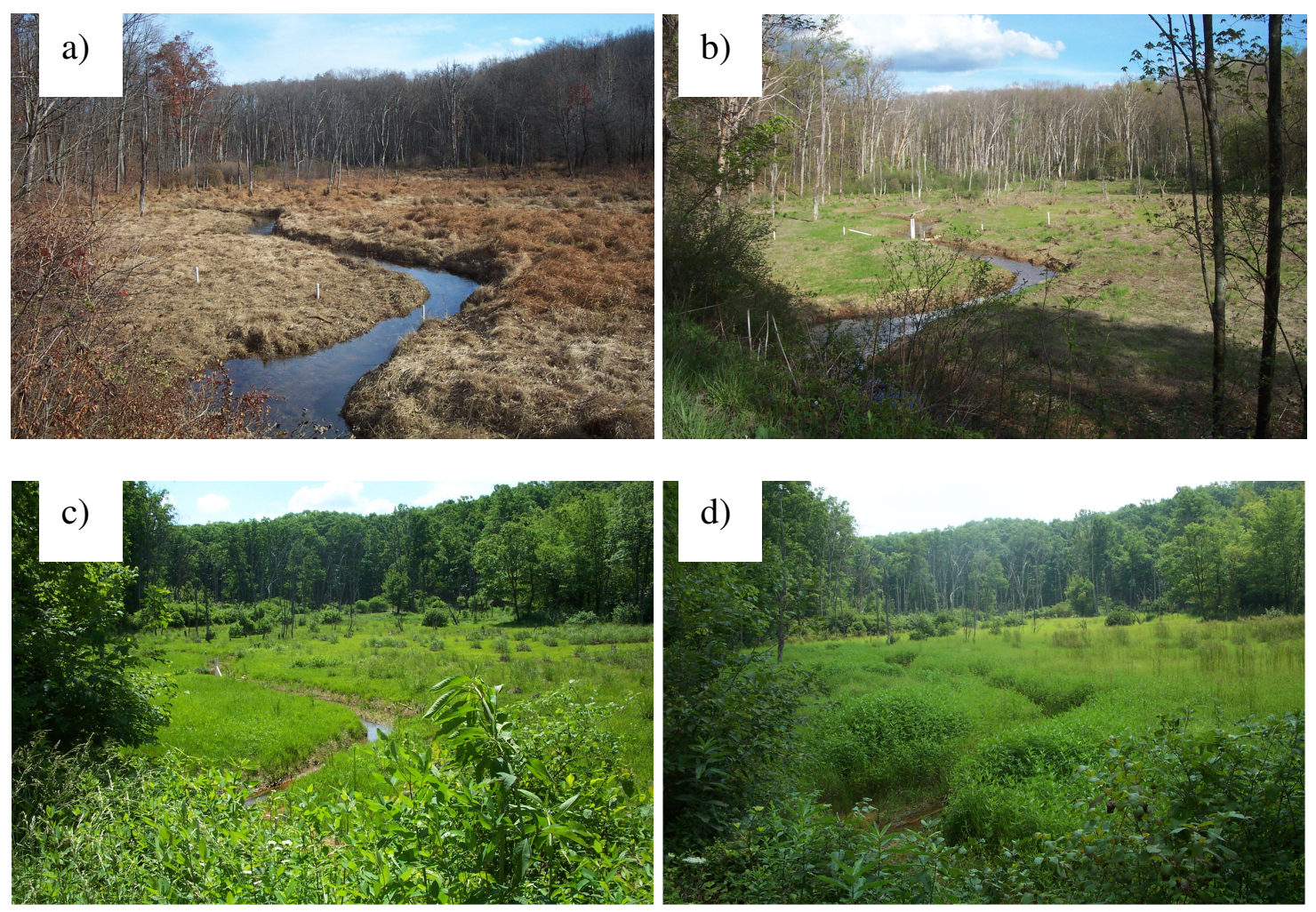

Figure 6-1: Vegetation differences at Dillan Creek depending on season. a: March 30 b: May 9 c: June 12 d: August 13. 


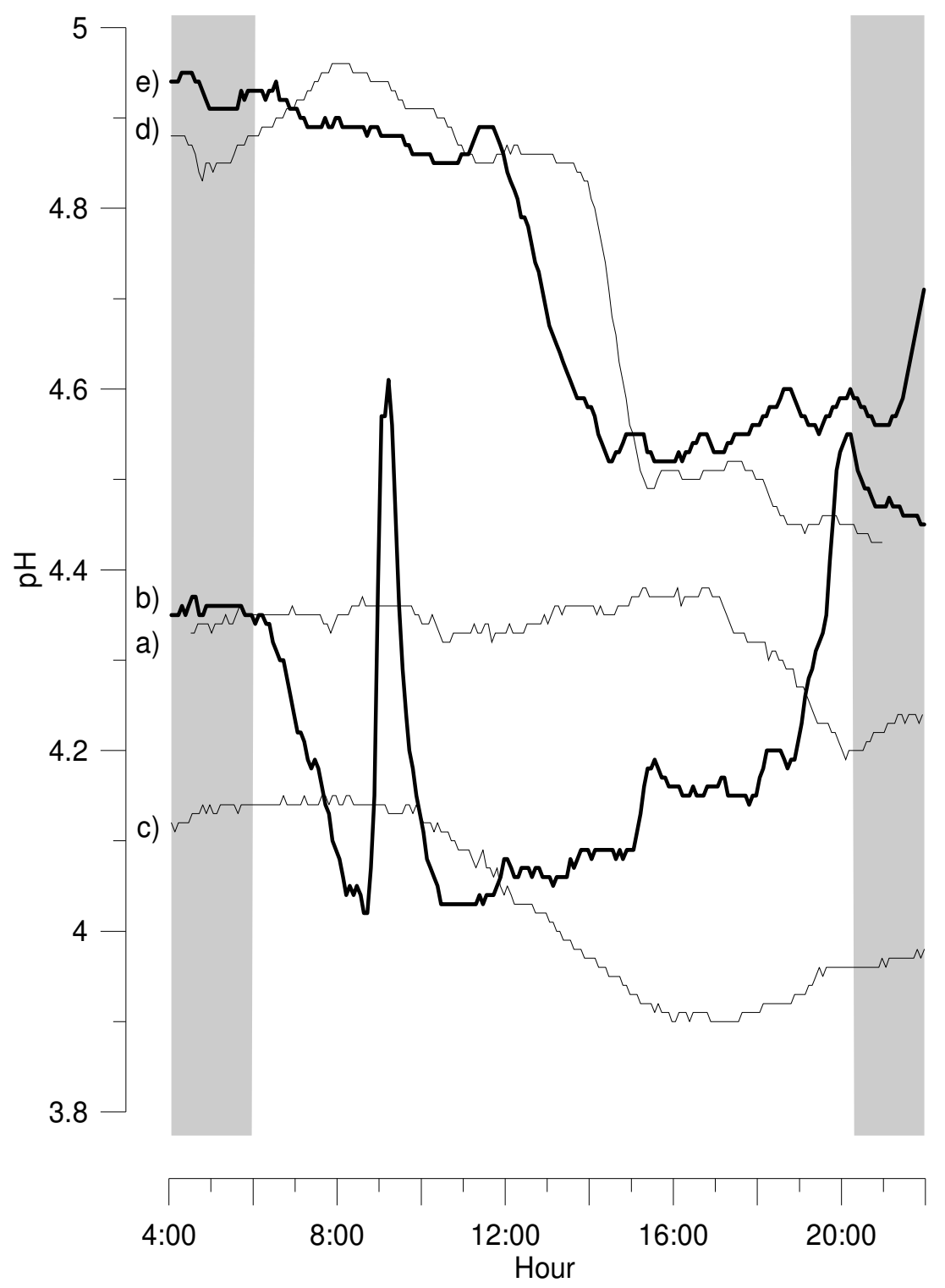

Figure 6-2: Seasonal pH variation in Dillan Creek, 2007. Shaded areas indicate average nighttime hours. a: March 30 b: May 9 c: June 12 d: August 13 e: August 15 

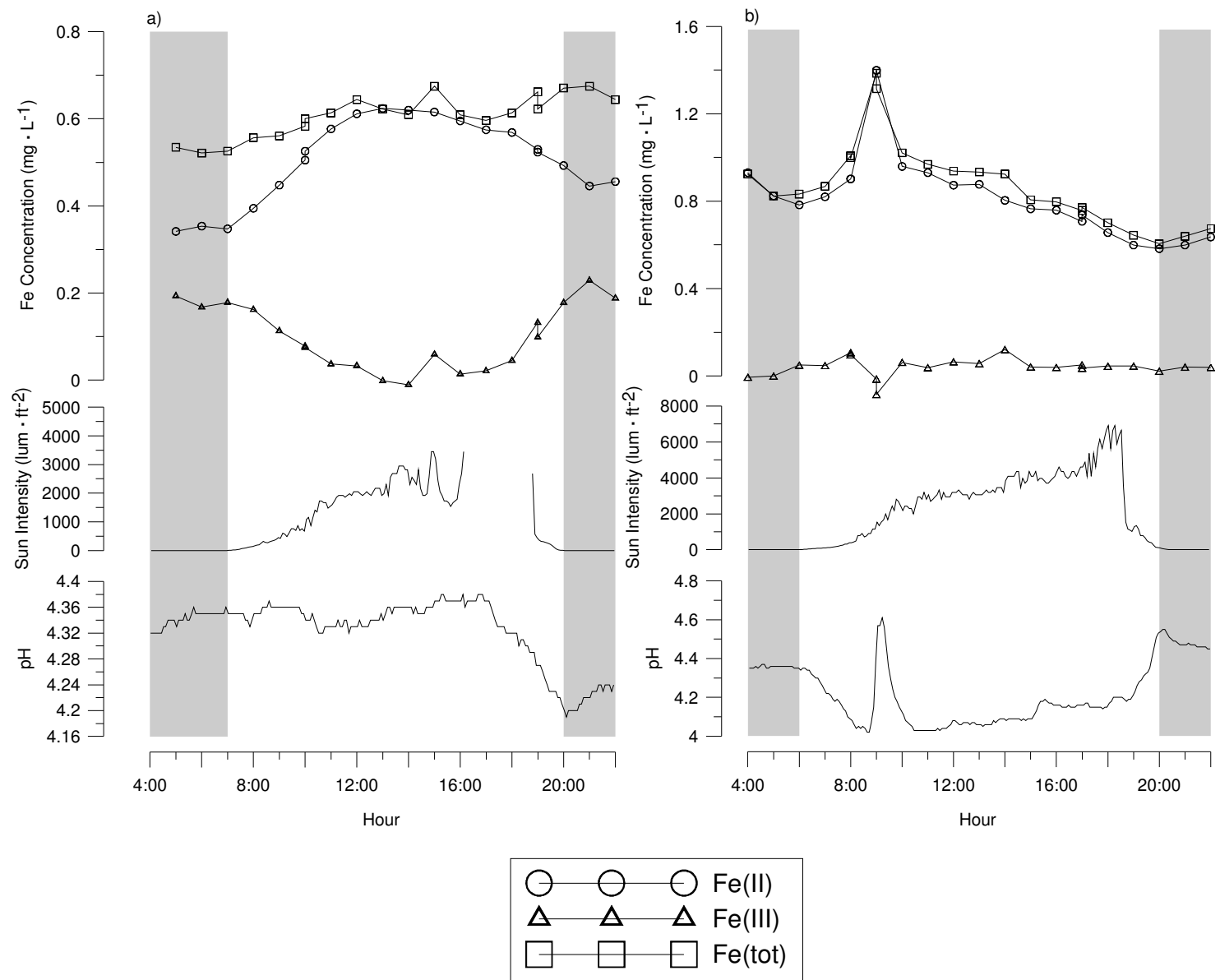

Figure 6-3a-b: Iron, $\mathrm{pH}$, and sunlight intensity data.

a: March 30 b: May 9 


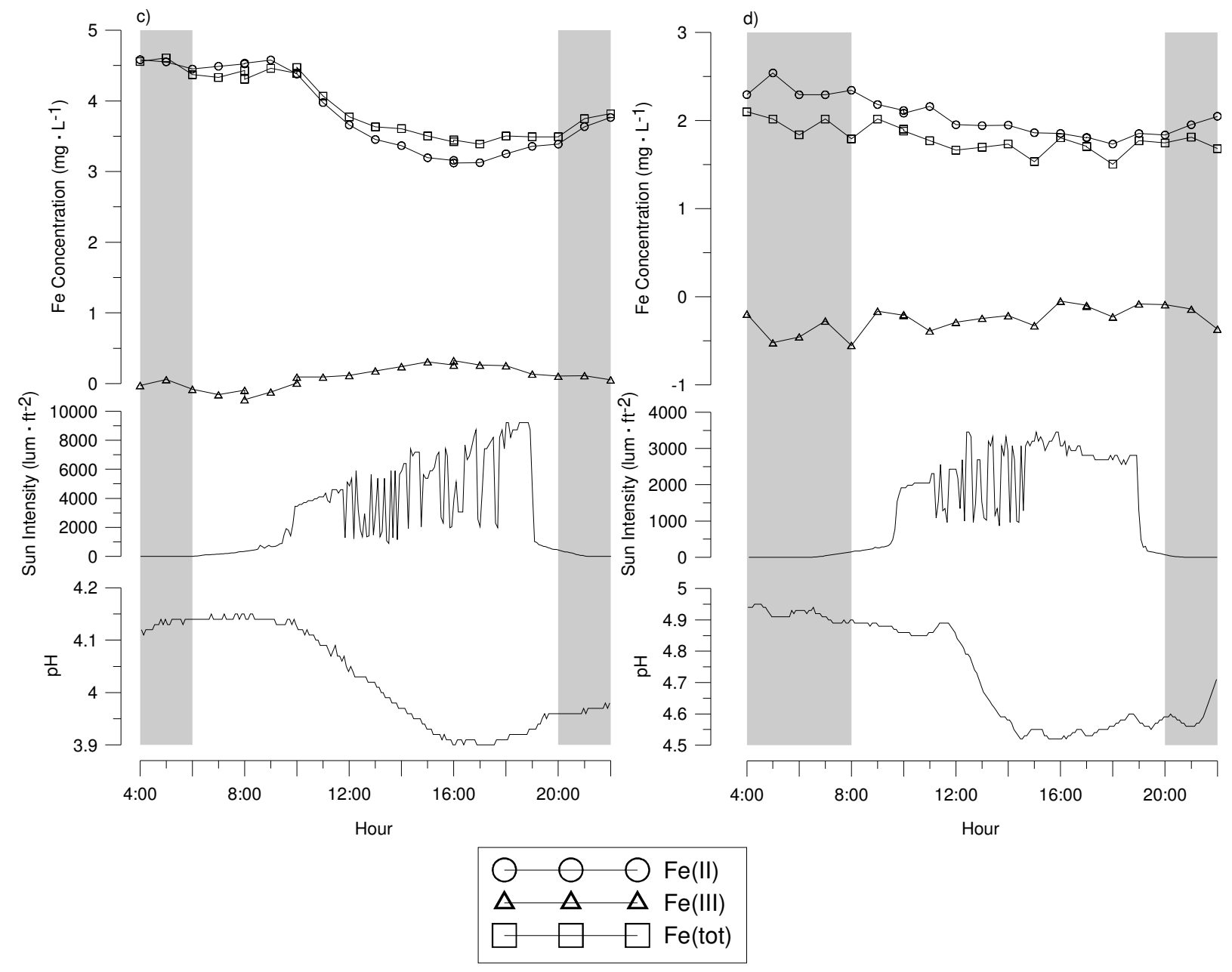

Figure 6-3c-d: Iron, $\mathrm{pH}$, and sunlight intensity data.

c: June 12 d: August 13 


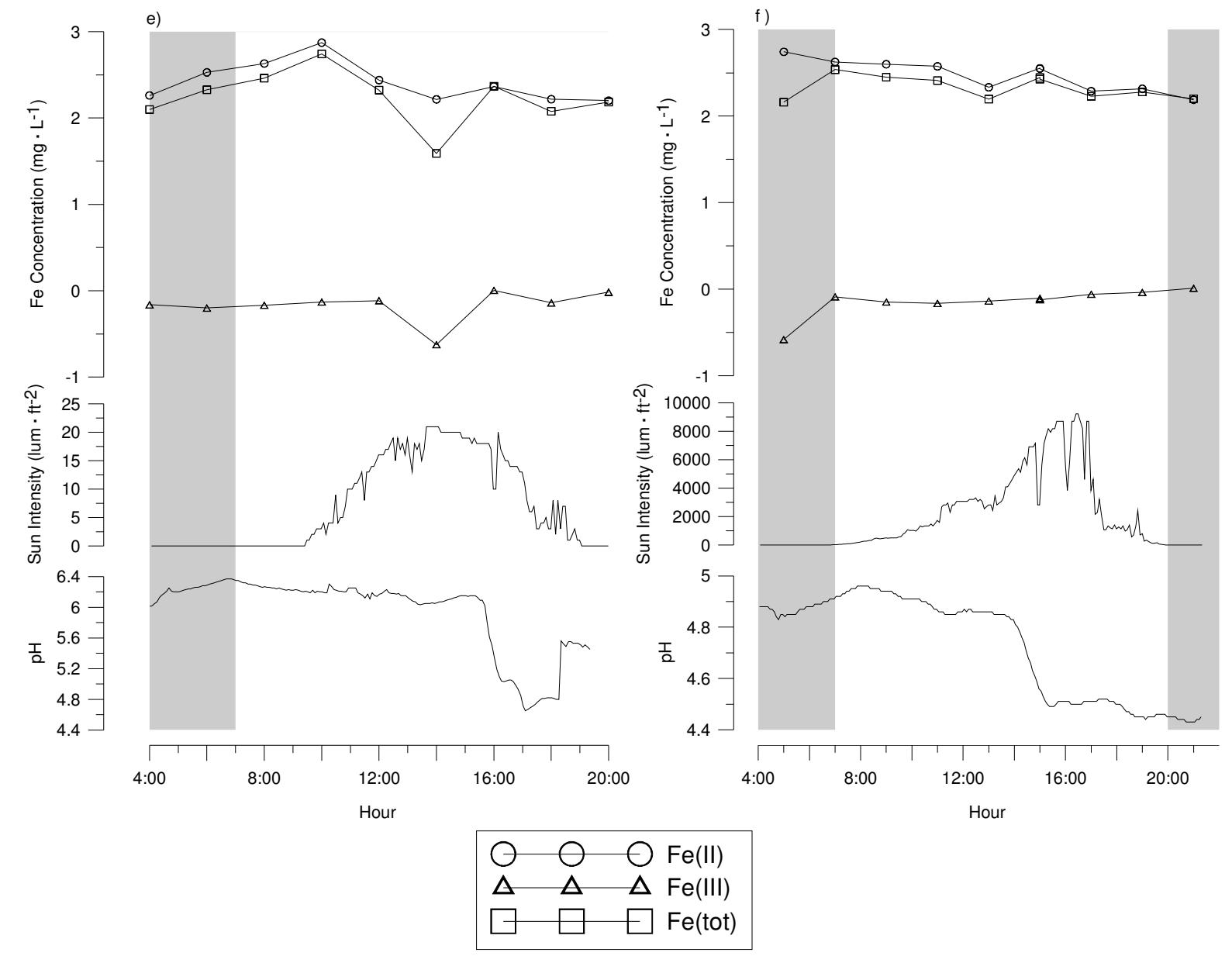

Figure 6-3e-f: Iron, $\mathrm{pH}$, and sunlight intensity data.

e: August 15 location 1 f: August 15 location 2 

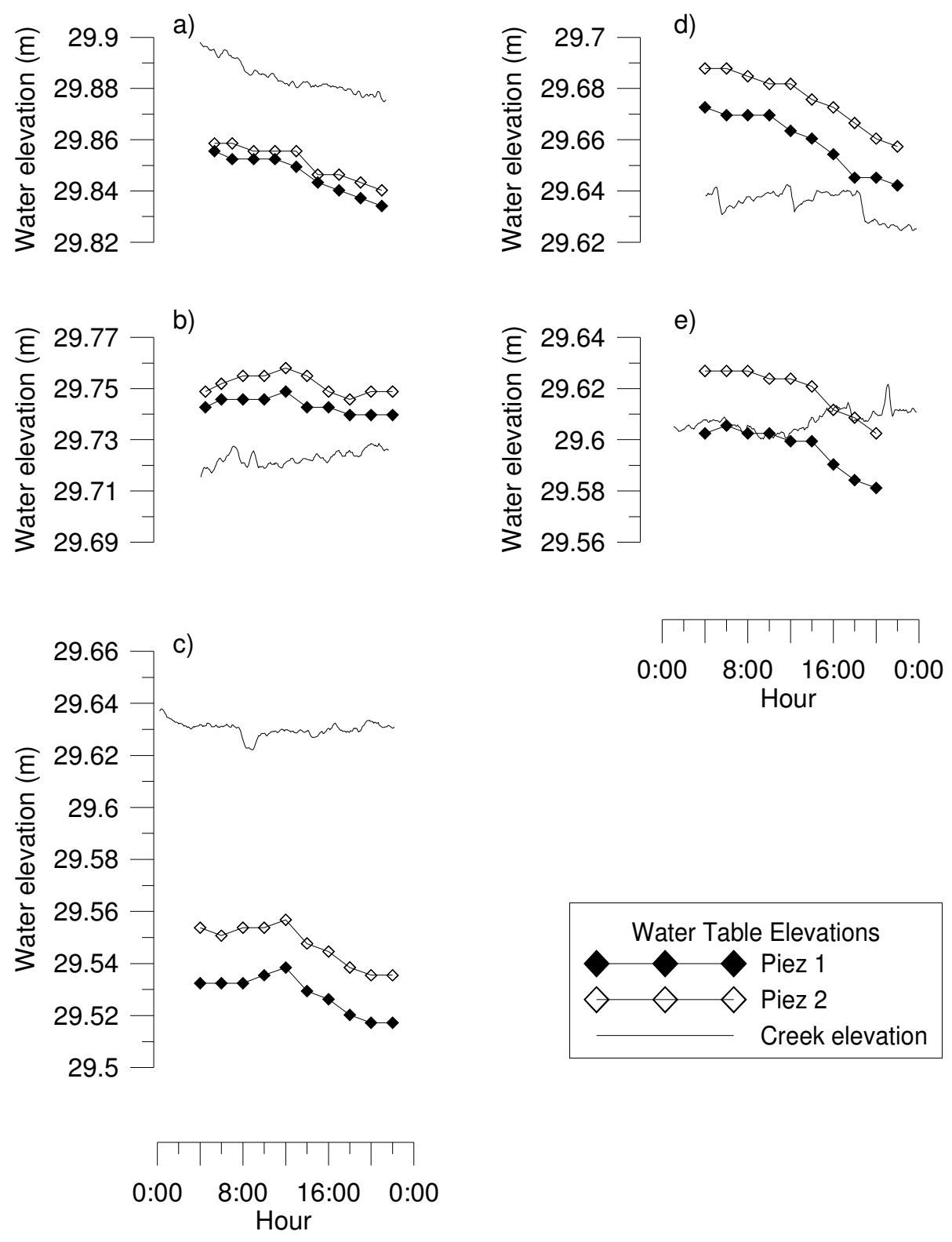
equal value. Creek stage was higher than groundwater elevation for the entire sampling session.

\subsection{May 9, 2007 data}

The second diel collection episode occurred on May 9, 2007. During this sampling episode, plant life was beginning to grow back, but was still minimal (Figure 61). Low grasses were abundant, but just beginning to thrive.

May 9 showed an average $\mathrm{pH}$ value of 4.22 with a total variation of $14.7 \%$ from a minimum value of 4.02 (Figure 6-2). Decreases in $\mathrm{pH}$ were witnessed from sunrise until mid-morning when a disturbance in the creek disrupted normal $\mathrm{pH}$ activity. The $\mathrm{pH}$ then increased slowly until sunset.

A diel cycle in iron species was again observed in early summer (Figure 6-3b). $\mathrm{Fe}(\mathrm{II})$ showed an increase in concentrations until it reached a maximum of $0.96 \mathrm{mg} / \mathrm{L}$ at 10:00. After this point, $\mathrm{Fe}(\mathrm{II})$ concentrations decreased until a minimum concentration of $0.58 \mathrm{mg} / \mathrm{L}$ was reached at 20:00, followed by a slight increase until the end of sampling. Total Fe concentrations mimicked Fe(II) concentrations in trend showing a maximum concentration at 10:00 and a minimum concentration at 20:00, followed by a slight increase. Because of the similar concentrations of $\mathrm{Fe}(\mathrm{II})$ and total Fe throughout the diel run, $\mathrm{Fe}(\mathrm{III})$ concentrations remained stable below detection the entire time. A maximum concentration of $0.12 \mathrm{mg} / \mathrm{L} \mathrm{Fe}(\mathrm{III})$ was noted at 14:00, but was significantly less with an average of $0.04 \mathrm{mg} / \mathrm{L}$ for most of the diel run. A spike in $\mathrm{pH}, \mathrm{Fe}(\mathrm{II})$, and $\mathrm{Fe}(\mathrm{III})$ was noted at 9:00. This abnormal peak was caused by wildlife interaction approximately 50 meters upstream.

The May 9 sampling session had minimal plant life growth, but showed a minor amount water table cycling (Figure 6-4). P1 showed a steady increase in water table elevation in the morning followed by a steady decrease in water table elevation until late afternoon, when it remained constant until the end of collection. In P2, a similar trend occurred where the groundwater elevation rose until noon followed by a decline nearly until the end of the sampling. PC showed negligible variation, indicating steady stage 
and discharge for the entire sampling interval. Creek stage was lower than groundwater elevations for the entire sampling session.

\subsection{June 12, 2007 data}

By mid June the vegetation in the meadow had partially returned (Figure 6-1). Low grasses were abundant, but not yet at the peak of their growth. Full foliage was present on the trees and bushes near the meadow. The grasses should account for the highest amount of evapotranspiration, so water table fluctuation should be visible, but not yet at maximum operation.

June 12 showed an average $\mathrm{pH}$ value of 4.02 with a total variation of $6.4 \%$ from a minimum value of 3.90 (Figure 6-2). Decreases in $\mathrm{pH}$ were witnessed from mid-morning until late afternoon and were followed by an increase until the end of sampling.

The sampling performed on this date again indicates a diel trend in iron species (Figure 6-3c). Fe(II) concentrations show a slight decline followed by a slight increase between the hours of 4:00 and 9:00 reaching a maximum concentration of $4.58 \mathrm{mg} / \mathrm{L}$ at 9:00. $\mathrm{Fe}(\mathrm{II})$ concentrations then fell throughout the day until 17:00 when a minimum concentration of $3.13 \mathrm{mg} / \mathrm{L}$ was reached, followed by a slight increase until the end of sampling. Total Fe concentrations mimic Fe(II) concentrations similar to the May sampling with the exception that total Fe concentrations are noticeably higher than $\mathrm{Fe}(\mathrm{II})$ concentrations from 12:00 to 19:00. During this time, total Fe concentrations are an average $0.23 \mathrm{mg} / \mathrm{L}$ higher than $\mathrm{Fe}(\mathrm{II})$ concentrations. Because of this trend, there is a small diel signal for Fe(III) during this diel run. Fe(III) remains stable below detection until 12:00 when it increases to $0.11 \mathrm{mg} / \mathrm{L}$. Fe(III) concentration continues to increase to a maximum of $0.31 \mathrm{mg} / \mathrm{L}$ at 15:00 before a subsequent decrease until the end of sampling.

$\mathrm{P} 1$ and P2 remained at a constant elevation until 12:00 when they fell slightly until the end of sampling (Figure 6-4). PC showed negligible variation, indicating steady stage and discharge for the entire sampling interval. Creek stage was higher than groundwater elevations for the entire sampling session. 


\subsection{August 13, 2007 data}

By August 13, plant life was abundant and fully grown (Figure 6-1). Grasses were at an average height between 1.0 and 1.5 meters. Full foliage was also present on all trees and bushes. The site during this time should have been experiencing full evapotranspirational influence due to the abundance of tall grasses.

August 13 showed an average $\mathrm{pH}$ value of 4.73 with a total variation of $9.5 \%$ from a minimum value of 4.52 (Figure 6-2). Decreases in $\mathrm{pH}$ were witnessed from latemorning until the afternoon. The $\mathrm{pH}$ increased again following sunset.

Another diel trend in iron species data was observed during this sampling episode (Figure 6-3d). Fe(II) concentrations showed a slight increase until a maximum concentration of $2.54 \mathrm{mg} / \mathrm{L}$ was achieved at 5:00. Fe(II) concentrations then decreased continuously until they reached a minimum concentration of $1.73 \mathrm{mg} / \mathrm{L}$ at 18:00. $\mathrm{Fe}(\mathrm{II})$ concentrations then increased constantly until the end of the sampling at 22:00. Total Fe concentration trends mimicked $\mathrm{Fe}$ (II) concentration trends showing a maximum concentration at 4:00 and a minimum concentration at 18:00. It is notable that total Fe concentrations are always less than $\mathrm{Fe}(\mathrm{II})$ concentrations for this diel run. Because of this, calculated Fe(III) concentrations appear to be negative, but in reality are always below detection, indicating that all iron present is in the Fe(II) species.

$\mathrm{P} 1$ and P2 showed a constant decrease over the entire sampling session, although decreases occurred more rapidly between 12:00 and 21:00 (Figure 6-4). PC showed minor variation, but no constant pattern of increase or decrease over the entire run. Creek stage was consistently lower than groundwater elevations for the entire sampling session.

\subsection{August 15, 2007 data}

August 15 had the same abundance of plant life and similar weather conditions as August 13. The $\mathrm{pH}$ for Dillan Creek was at an average of 4.74 showing a total variation of $12.0 \%$ from a minimum value of 4.43 (Figure 6-2). Decreases in $\mathrm{pH}$ were witnessed from just after sunrise to the end of sampling. The only increases in $\mathrm{pH}$ were witnessed 
before sunrise. While two locations were examined, hydrologic information was only available at location 1. P1 and P2 showed constant water table elevation until 12:00 when they both decreased gradually until the end of sampling (Figure 6-4). PC showed constant creek stage with the exception of a small increase from 12:00 to 16:00. Creek stage was lower than groundwater during the morning, but higher than groundwater in the afternoon.

\subsubsection{Location 1}

A diel cycle in iron species was observed at location 1 despite the sun blocking material upstream (Figure 6-3e). Diel iron trends for this date were similar to cycles witnessed during May and June. Fe(II) increased from the beginning of sampling through 10:00 where it reached a maximum concentration of $2.87 \mathrm{mg} / \mathrm{L}$. Fe(II) concentrations then decreased gradually through the end of the sampling session, reaching a minimum concentration of $2.20 \mathrm{mg} / \mathrm{L}$ at 20:00. Total Fe mimicked Fe(II) concentrations showing a maximum at 10:00 followed by a decrease in concentration until the end of sampling. The minimum total Fe concentration was reached at 14:00.

Similar to the August 13 sampling episode, Fe(II) concentrations were always higher than total Fe concentrations. This is again an indication that all iron present during sample collection was in the Fe(II) species. Therefore, Fe(III) remained constant below detection.

\subsubsection{Location 2}

A diel cycle in iron species also occurred at the uncovered location 2, approximately 30.5 meters upstream of location 1 (Figure 6-3f). Fe(II) concentrations showed a gradual decrease throughout the entire sampling interval. The lack of an initial increase in $\mathrm{Fe}$ (II) concentration may be due to the collection of samples at this location every second hour rather than hourly as is typical. Because of this interval, the inflection typically seen near sunrise is not visible. Fe(II) concentrations were at their maximum at 
5:00 with a concentration of $2.74 \mathrm{mg} / \mathrm{L}$. Fe(II) concentrations then decreased through the rest of the sampling. Total Fe concentrations showed the same trend as Fe(II) with the exception of a small increase in total Fe from 5:00 to 7:00. Total Fe concentrations then decreased through the end of sampling.

Again, total Fe concentrations were always less than Fe(II) concentrations, causing calculated Fe(III) concentrations to always be below detection. At location 1, the covered section, maximum $\mathrm{Fe}$ (II) concentration was witnessed at 10:00, while at location 2, maximum Fe(II) concentration was witnessed at 5:00. 


\subsection{Data interpretation}

\subsection{Seasonal comparisons}

Differences in magnitude and timing of iron cycles according to season are noticeable. The higher discharge of Dillan Creek in the winter dilutes the overall concentration of iron, showing the lowest overall concentration during the March 30 sampling event (Table 7-1). All other sampling days show higher concentrations due to decreased discharge. There is a noticeable difference in season when comparing iron percent variation of Fe(II) on each day (Figure 7-1, Table 7-1). As the seasons change from winter to summer, percent Fe(II) variation per day decreases, showing a minimum decrease on the August 15. There is also a noticeable difference in timing of $\mathrm{Fe}(\mathrm{II})$ maximum and minimum concentrations. During March 30, the maximum concentration of $\mathrm{Fe}$ (II) occurs in the afternoon, while all other sampling days show a maximum $\mathrm{Fe}(\mathrm{II})$ concentration during the morning (Figure 7-1). March 30 shows a minimum Fe(II) concentration in the morning, while all other sampling days show a minimum Fe(II) concentration in the evening.

All cycles in $\mathrm{pH}$ showed an overall decrease in $\mathrm{pH}$ during the day and a subsequent increase in $\mathrm{pH}$ overnight (Figure 6-2). There are some differences in $\mathrm{pH}$ cycles according to seasonality however. One difference observed between $\mathrm{pH}$ cycles is that late winter cycles have a smaller range as compared to summer cycles. During the late winter sampling episode, $\mathrm{pH}$ was at an average of 4.29 and showed a fluctuation of 0.19. During summer sampling, $\mathrm{pH}$ cycles showed a much higher variability of 0.49 with an average $\mathrm{pH}$ of 4.77 on the August 13 sampling run. Diel sampling episodes during the months in between these two dates show intermediate $\mathrm{pH}$ fluctuations that lie between the minimum variability of 0.19 and the maximum variability of 0.49 . There is also a slight increase in average $\mathrm{pH}$ values of about $0.70 \mathrm{pH}$ units from late winter to summer. 
Table 7-1: Fe(II) concentration changes per diel session.

\begin{tabular}{|c|c|c|c|c|}
\hline Date & & $\begin{array}{c}\text { Concentration } \\
{[\mathrm{mg} / \mathrm{L}]}\end{array}$ & $\%$ difference & $\begin{array}{c}\text { Mean temp } \\
{\left[{ }^{\circ} \mathrm{C}\right]}\end{array}$ \\
\hline $3-30-2007$ & Max & 0.62 & 45.3 & 8.95 \\
\hline $3-30-2007$ & Min & 0.34 & & \\
\hline 5-9-2007 & Max & 0.96 & 39.3 & 15.22 \\
\hline 5-9-2007 & Min & 0.58 & & \\
\hline 6-12-2007 & $\operatorname{Max}$ & 4.58 & 31.9 & 20.65 \\
\hline $6-12-2007$ & Min & 3.13 & & \\
\hline 8-13-2007 & Max & 2.54 & 31.8 & 19.97 \\
\hline 8-13-2007 & Min & 1.73 & & \\
\hline $8-15-2007$ loc1 & Max & 2.87 & 23.4 & 18.46 \\
\hline 8-15-2007 loc1 & Min & 2.20 & & \\
\hline 8-15-2007 loc2 & $\operatorname{Max}$ & 2.74 & 20.2 & 18.46 \\
\hline 8-15-2007 loc2 & Min & 2.19 & & \\
\hline
\end{tabular}

$* \%$ difference calculated as difference between maximum and minimum concentration divided by minimum concentration. 

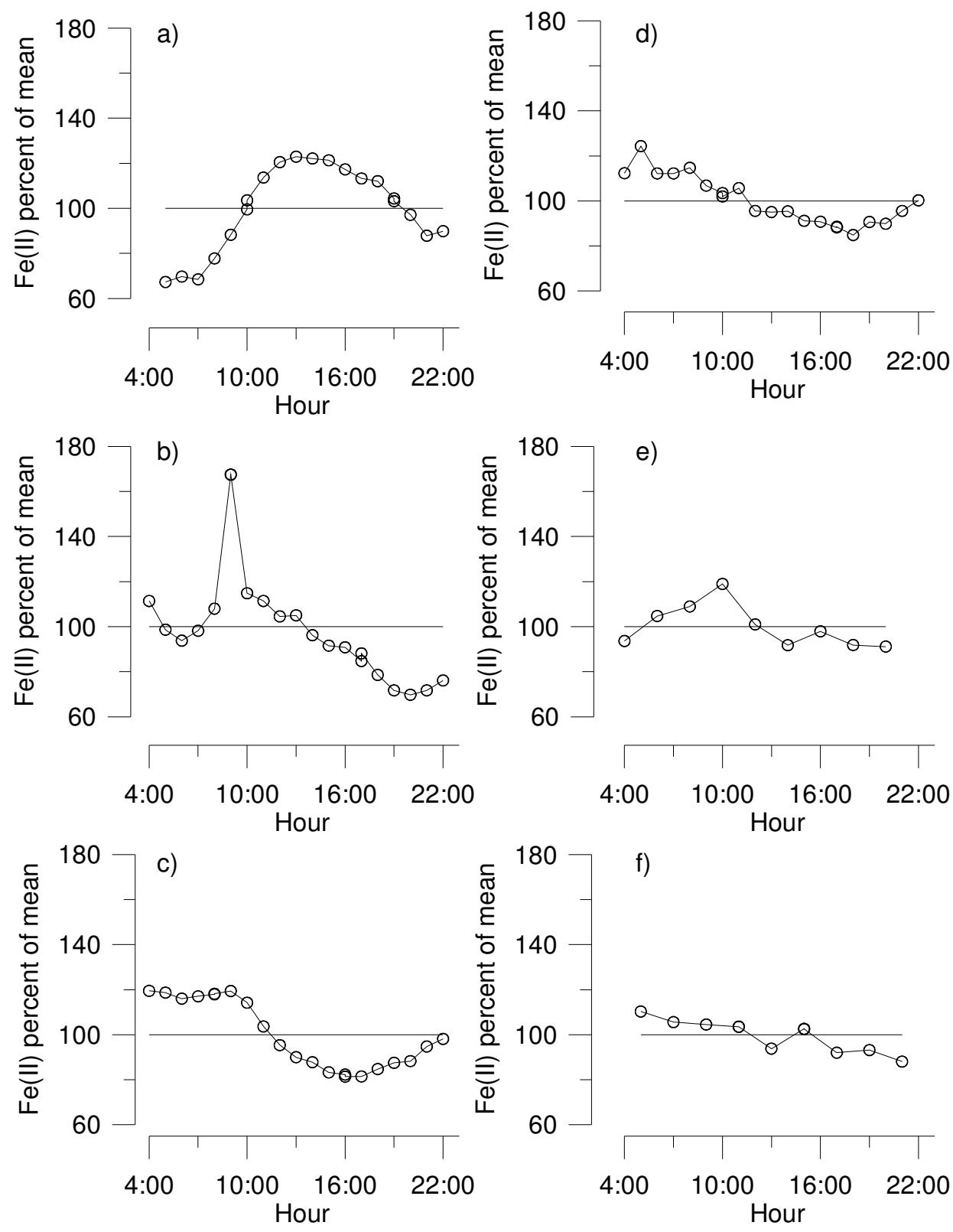

Figure 7-1: Fe(II) concentrations plotted as percent of mean. a: March 30 b: May 9 c: June 12 d: August 13 e: August 15 location 1 f: August 15 location 2 


\subsection{Modeled changes in $\mathrm{pH}$ values}

If controlled by photosynthesis, $\mathrm{pH}$ cycles will show an increase in $\mathrm{pH}$ during the day and a subsequent decrease during the night (Liu et al., 2006). These cycles are caused by plant interaction through increased photosynthetic processes during times when abundant sunlight is available. The process of photosynthesis consumes $\mathrm{CO}_{2}$ during daylight, causing an increase in $\mathrm{pH}$. At night, when sunlight is no longer available, photosynthetic reactions cease, causing a decrease in $\mathrm{pH}$. Cycles witnessed in Dillan Creek show the opposite trend, however (Figure 6-2). All data collected at Dillan Creek show a decrease of $\mathrm{pH}$ during the day, followed by a subsequent increase in $\mathrm{pH}$ during the night. Photosynthetic processes likely occurring in Dillan Creek must be overwhelmed by another mechanism causing $\mathrm{pH}$ fluctuations.

Another possibility for $\mathrm{pH}$ cycles witnessed in Dillan Creek could be $\mathrm{pH}$ fluctuations associated with the speciation of iron. Assuming that the dominant species of $\mathrm{Fe}(\mathrm{III})$ is $\mathrm{Fe}(\mathrm{OH})_{3}$, which is possible in a $\mathrm{pH}$ range of 4-6, the likely inorganic oxidation-reduction reactions are listed in Table 7-2 (Vile and Wieder, 1993). Alternately, organic reduction of $\mathrm{Fe}(\mathrm{OH})_{3}$ may also occur assuming lactate as a carbon source in passive treatment of wetlands (Vile and Wieder, 1993). This equation yields a net production of 2 mols $\mathrm{OH}^{-}$per mol $\mathrm{Fe}(\mathrm{OH})_{3}$ reduced. For Fe(II) oxidation, 2 mols of

$\mathrm{H}^{+}$are produced per mol of $\mathrm{Fe}^{2+}$ reduced. For the reduction of $\mathrm{Fe}(\mathrm{III})$, equation $\mathrm{f}$ shows a net consumption of 2 mols $\mathrm{H}^{+}$per mol reduced Fe(III). Equation g shows a new production of 2 mols $\mathrm{OH}^{-}$per mol of Fe(III) reduced (Table 7-2).

The changes in $\mathrm{pH}$ driven by changes in molar concentrations of $\mathrm{Fe}(\mathrm{II})$ and $\mathrm{Fe}(\mathrm{III})$ were calculated (Figure 7-2) and compared to the observed pH changes (Figure 73). Using equations a through $\mathrm{g}$ (Table 7-2), fluctuations in $\left[\mathrm{H}^{+}\right]$associated with production or consumption of $\mathrm{Fe}(\mathrm{II})$ and $\mathrm{Fe}(\mathrm{III})$ were calculated. These changes in $\left[\mathrm{H}^{+}\right]$ were used to model $\mathrm{pH}$ fluctuations in $\mathrm{pH}$ associated with $\mathrm{Fe}(\mathrm{II})$ and $\mathrm{Fe}(\mathrm{III})$ concentration cycles.

The predicted $\mathrm{pH}$ fluctuation based solely on iron species changes shows a similar trend to the observed $\mathrm{pH}$ changes during diel runs for most days (Figure 7-3). Particularly, the June 12 and August 13 cycles are very similar (Figure 7-4), with high R- 
Table 7-2: Potential iron reactions and their impact on $\mathrm{pH}$. Modified from (Vile and Wieder, 1993).

\begin{tabular}{|c|c|c|}
\hline \multicolumn{3}{|c|}{ Inorganic redox reactions } \\
\hline \multirow{3}{*}{$\begin{array}{l}\text { Stepwise } \\
\text { reactions }\end{array}$} & Oxidation of $\mathrm{Fe}(\mathrm{II})$ & Reduction of Fe(III) \\
\hline & $4 \mathrm{Fe}^{2+}+\mathrm{O}_{2}+4 \mathrm{H}^{+} \rightarrow 4 \mathrm{Fe}^{3+}+2 \mathrm{H}_{2} \mathrm{O} \quad[\mathrm{d}]$ & $12 \mathrm{H}^{+}+4 \mathrm{Fe}(\mathrm{OH})_{3} \rightarrow 4 \mathrm{Fe}^{3+}+12 \mathrm{H}_{2} \mathrm{O} \quad[\mathrm{g}]$ \\
\hline & $4 \mathrm{Fe}^{3+}+12 \mathrm{H}_{2} \mathrm{O} \rightarrow 12 \mathrm{H}^{+}+4 \mathrm{Fe}(\mathrm{OH})_{3} \quad[\mathrm{e}]$ & $4 \mathrm{Fe}^{3+}+2 \mathrm{H}_{2} \rightarrow 4 \mathrm{Fe}^{2+}+4 \mathrm{H}^{+}$ \\
\hline $\begin{array}{l}\text { Total } \\
\text { reaction }\end{array}$ & $4 \mathrm{Fe}^{2+}+\mathrm{O}_{2}+10 \mathrm{H}_{2} \mathrm{O} \rightarrow 8 \mathrm{H}^{+}+4 \mathrm{Fe}(\mathrm{OH})_{3}[\mathrm{f}]$ & $8 \mathrm{H}^{+}+4 \mathrm{Fe}(\mathrm{OH})_{3}+2 \mathrm{H}_{2} \rightarrow 12 \mathrm{H}_{2} \mathrm{O}+4 \mathrm{Fe}^{2+}$ \\
\hline $\mathrm{pH}$ effect & 2 mols $\mathrm{H}^{+}$produced per mol $\mathrm{Fe}^{2+}$ consumed & 2 mols $\mathrm{H}^{+}$consumed per mol Fe ${ }^{2+}$ produced \\
\hline
\end{tabular}

Organic redox reactions

Reduction of Fe(III)

Total $\quad 4 \mathrm{Fe}(\mathrm{OH})_{3}+4 \mathrm{CH}_{3} \mathrm{CH}(\mathrm{OH}) \mathrm{COO}^{-} \rightarrow 4 \mathrm{CO}_{2}+6 \mathrm{H}_{2}+4\left(\mathrm{C}_{2} \mathrm{H}_{3} \mathrm{O}_{2}\right)^{-}+8 \mathrm{H}^{-}+4 \mathrm{Fe}^{2+} \quad[\mathrm{j}]$ reaction

2 mols $\mathrm{H}^{+}$consumed per mol Fe ${ }^{2+}$ produced 
Step 0:

$\mathrm{Fe}(\mathrm{II})$ and $\mathrm{pH}$ measured

Each subsequent step:

$\Delta \mathrm{Fe}(\mathrm{II})$ measured

\begin{tabular}{|l|l|}
\hline If $\mathrm{Fe}(\mathrm{II})$ & Than \\
\hline decreases & $\mathrm{Fe}(\mathrm{II}) \rightarrow \mathrm{Fe}(\mathrm{III})$ \\
\hline increases & $\mathrm{Fe}(\mathrm{III}) \rightarrow \mathrm{Fe}(\mathrm{II})$ \\
\hline
\end{tabular}

Assuming that changes in $\mathrm{Fe}(\mathrm{II})$ concentration are related to redox reactions listed in Table 7-1

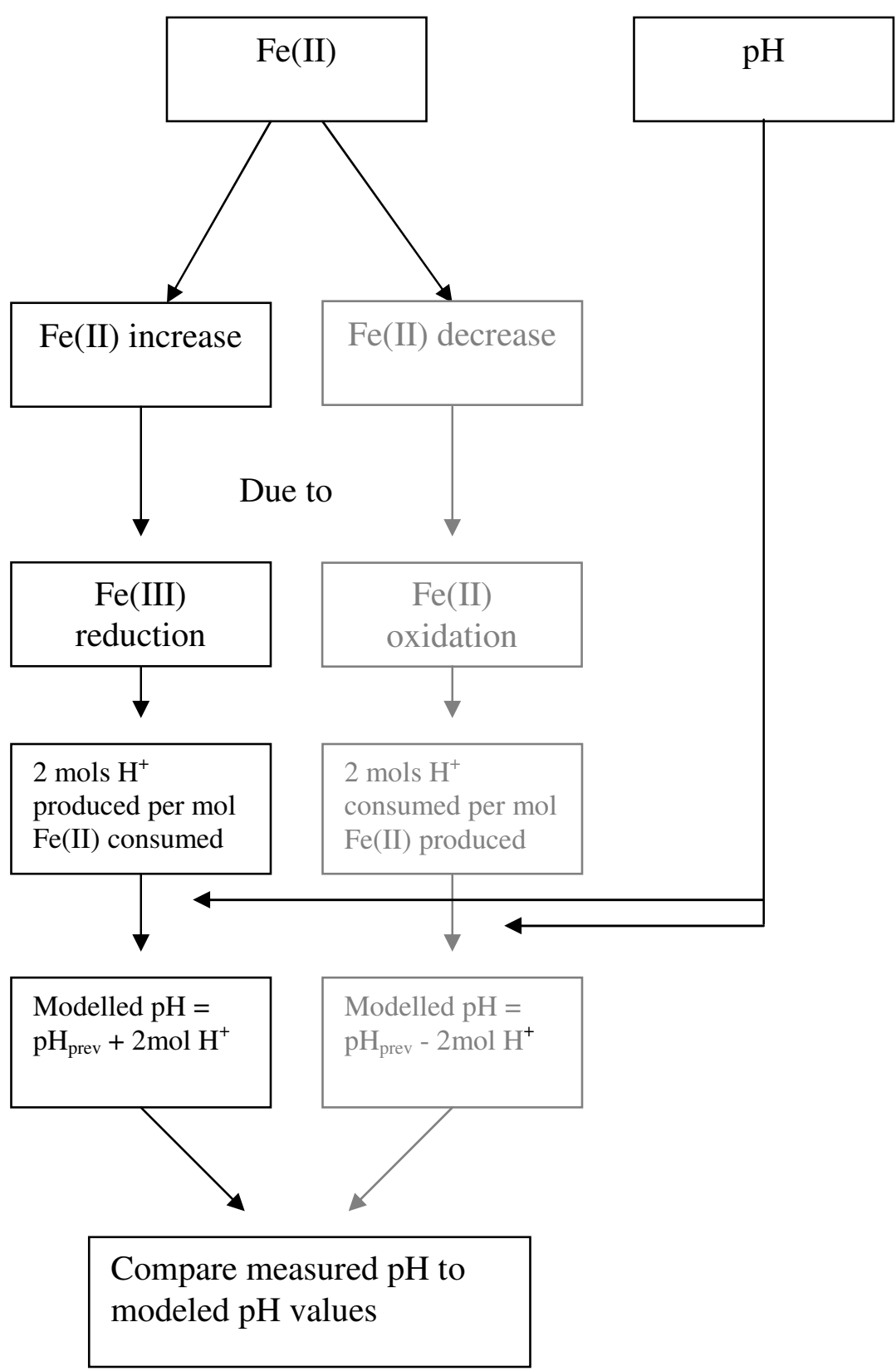

Figure 7-2: Method used for modeling of $\mathrm{pH}$ fluctuation due to changes in $\mathrm{Fe}(\mathrm{II})$ concentration. 

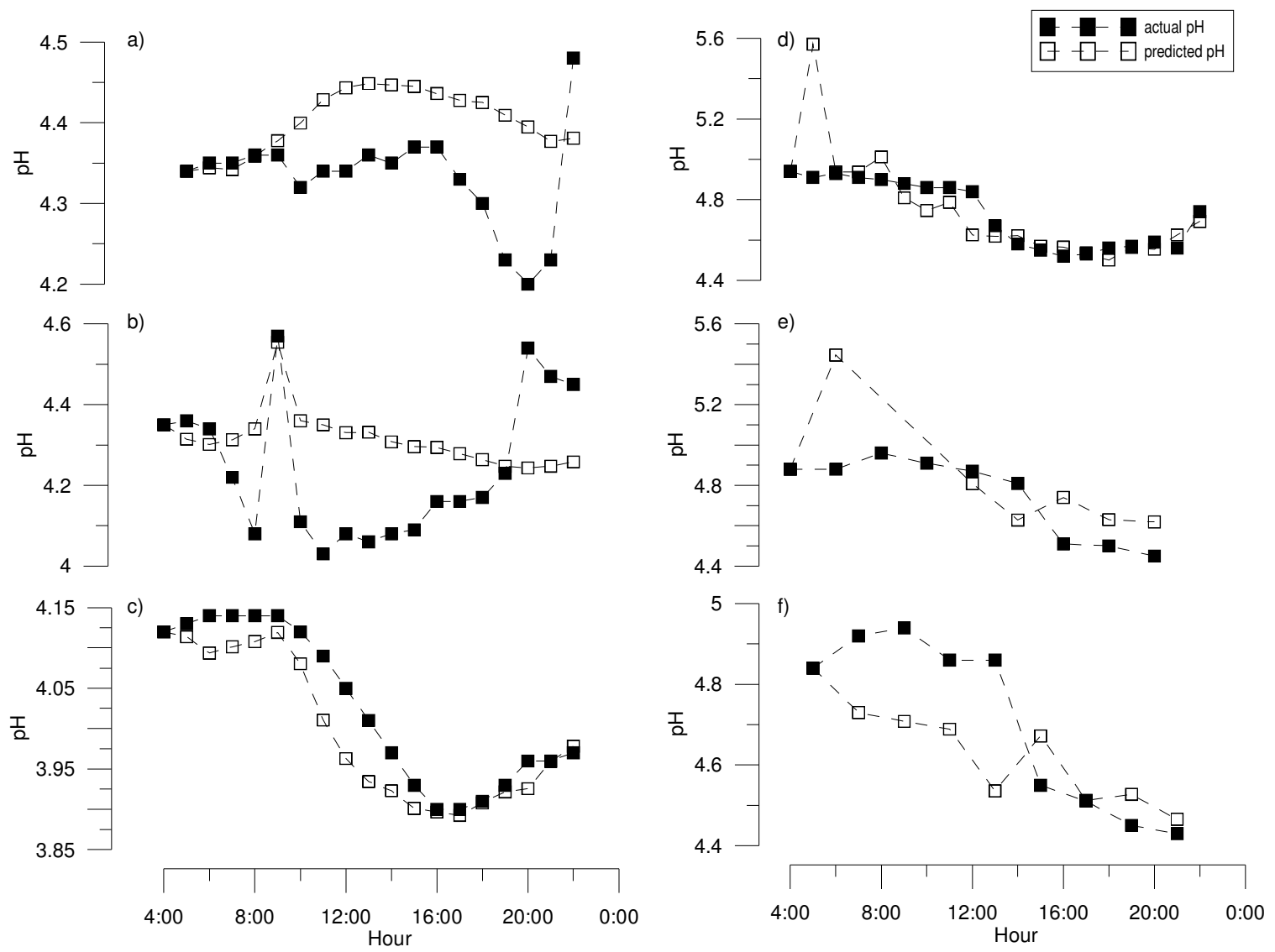

Figure 7-3: Actual pH fluctuations seen in Dillan Creek compared to modeled values of pH according to Fe speciation controls. a: March 30 b: May 9 c: June 12 d: August 13 e: August 15 location 1 f: August 15 location 2 

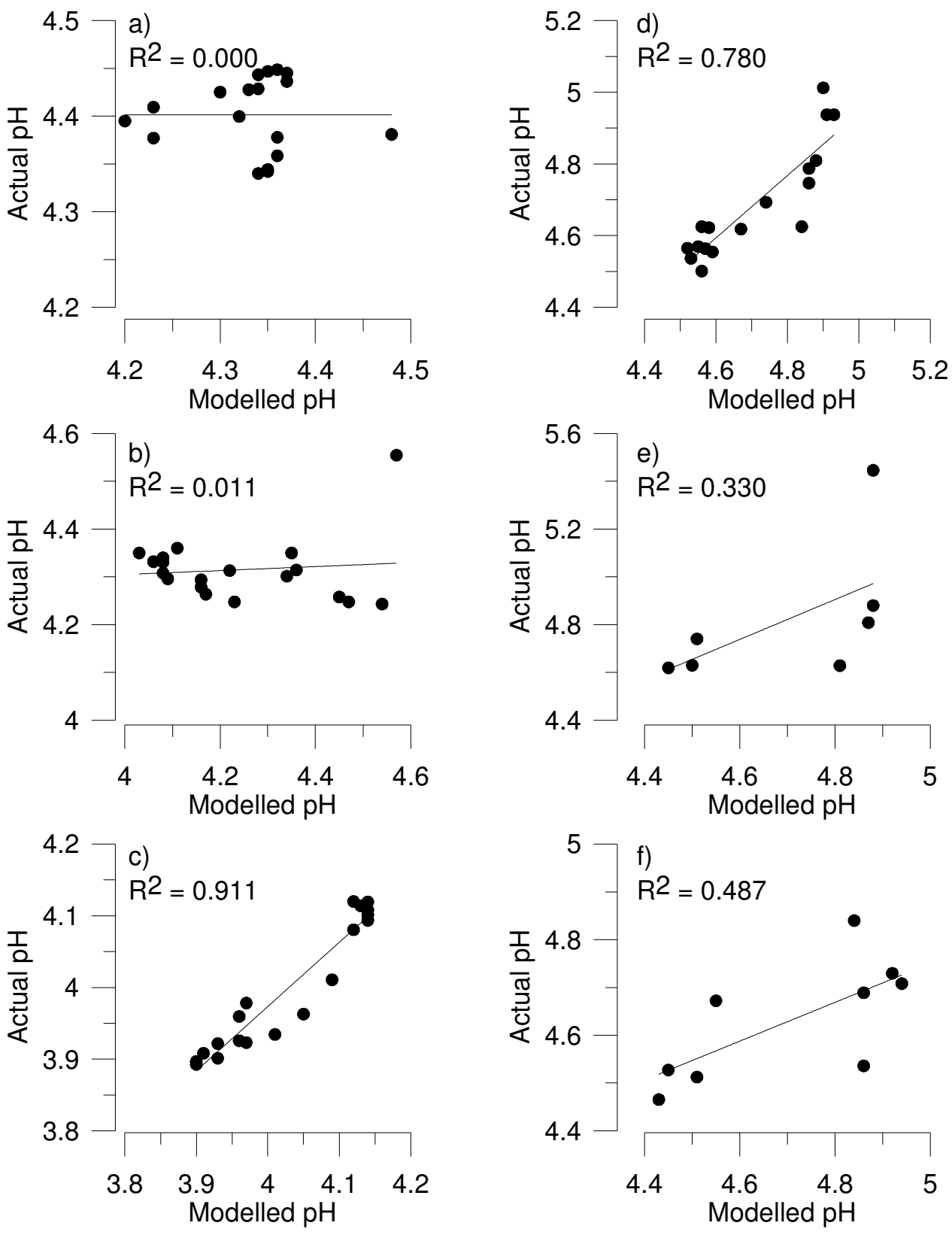

Figure 7-4: Correlations for actual $\mathrm{pH}$ and modeled $\mathrm{pH}$ values.

a: March 30 b: May 9 c: June 12 d: August 13 e: August 15 location 1 f: August 15 location 2 
squared values between the observed and modeled values (0.911 and 0.780 respectively). March 30 and May 9 data, however, show very low R-squared values of approximately 0.000 and 0.010 respectively. Critical R-squared values at $\alpha=0.05$ are listed in Table 73 and lead to the acceptance of the null hypothesis that the relationship between modeled $\mathrm{pH}$ values and actual $\mathrm{pH}$ values are random on March 30, May 9 and August 15 location 1. The null hypothesis is rejected for June 12, August 13, and August 15 location 2, meaning that correlation is seen on those days. While the null hypothesis is rejected for three dates, the visual trend between actual and modeled $\mathrm{pH}$ values is similar despite low correlation. The observed $\mathrm{pH}$ on May 9 shows an abnormal spike at 9:00. Coincident with this $\mathrm{pH}$ jump at 9:00 is also a spike in $\mathrm{Fe}(\mathrm{II})$ concentration (Figure 7-3) caused by wildlife interaction in the creek. This interaction with the creek may have stirred up sediments causing an increase in Fe(II) which was likely settled in the substrate, then dissolved back when disturbed. The wildlife interaction may have also stirred up high pH sediment pore water, which could also explain the spike witnessed at 9:00. This increase in $\mathrm{Fe}(\mathrm{II})$ at 9:00 causes a spike in predicted $\mathrm{pH}$ which matches almost exactly to the observed pH spike. Because of this, it is likely that the sudden increase in Fe(II) concentration is also responsible for the sudden increase in $\mathrm{pH}$ at 9:00. The lack of correlation on March 30 and May 9 suggests a separate mechanism for $\mathrm{pH}$ cycles during late winter and the transition into spring. It is possible that $\mathrm{pH}$ cycles for winter are affected in a separate manner than the rest of the year. While it is unlikely that iron speciation is the only driving factor for $\mathrm{pH}$ changes, it is likely that iron speciation has a significant effect on $\mathrm{pH}$ in Dillan Creek.

This model does show similarities between modeled values of $\mathrm{pH}$ and actual measured values of $\mathrm{pH}$, but there are several limitations to this model. Lack of more specific information about what particular iron species are present as well as what other ions are present in the system makes this model suspect. Without more specific ion information, the exact reactions occurring in the system are impossible to predict. 
Table 7-3: Critical R-squared values used for assessment of $\mathrm{pH}$ model*. Values modified from (Kachigan, 1982).

\begin{tabular}{ccccc|c} 
& 2-tailed & & \multicolumn{2}{c|}{ Critical R-squared at ó } & $\begin{array}{c}\text { R-squared } \\
\text { date }\end{array}$ \\
$\mathrm{n}$ & $\mathrm{df}$ & 0.05 & 0.01 & 01 \\
\hline $3-30$ & 18 & 16 & 0.219 & 0.348 & 0.000 \\
$5-9$ & 19 & 17 & 0.208 & 0.331 & 0.011 \\
$6-12$ & 19 & 17 & 0.208 & 0.331 & 0.911 \\
$8-13$ & 19 & 17 & 0.208 & 0.331 & 0.780 \\
$8-15$ loc1 & 9 & 7 & 0.444 & 0.637 & 0.330 \\
$8-15$ loc2 & 9 & 7 & 0.444 & 0.637 & 0.487
\end{tabular}

The null hypothesis states that the relationship between the modelled and actual values of $\mathrm{pH}$ is random Gray results indicate acceptance of the null hypothesis at ó $=0.05$

*Unshaded areas indicate statistical correlation at $\alpha=0.05$ 


\subsection{Statistical analysis of iron data}

In order to determine the relationship between Fe(II) concentrations and possible controlling mechanisms, correlation and factor analyses were used to observe the relationships between each mechanism and Fe(II) cycles. Due to differences in Fe(II) samples in each diel round a different critical $\mathrm{R}$ was necessary for each correlation (Kachigan, 1982). These critical R-squared values were tabulated in Table 7-4 and the null hypothesis states that there is no correlation between $\mathrm{Fe}(\mathrm{II})$ concentration and the selected parameter. Calculated correlations between Fe(II) and each selected parameter are also listed in Table 7-4. Parameters selected for statistical analysis include Fe(II) concentration, $\mathrm{Fe}$ (III) concentration, total Fe concentration, sunlight intensity, water temperature, $\mathrm{pH}$, and water table elevations. These mechanisms were selected since they are commonly cited for controlling the diel behavior of Fe(II) in AMD impacted waters (Gammons et al., 2005a; McKnight et al., 1988; McKnight et al., 2001; Nimick et al., 2003; Wieder, 1994). Correlations for August 15 at location 1 and location 2 were excluded due to inaccuracies stemming from the low amount of data for each location. Factor analysis was also run for all parameters.

\subsection{Fe(II) and sunlight correlation}

Correlations between $\mathrm{Fe}(\mathrm{II})$ concentrations and sunlight intensities were calculated to view their relationship (Figure 7-5). The diel episode that showed the highest R-squared value was the March 30 diel run, with the next highest R-squared on June 12. Another noteworthy trend in these analyses is that the March 30 data shows a positive correlation (positive r) between sunlight intensity and $\mathrm{Fe}$ (II) concentration, while all other sampling days show a negative correlation (negative $r$ ) where increasing sunlight indicates decreased $\mathrm{Fe}$ (II) concentrations. Also, the lowest R-squared value for sunlight intensity and $\mathrm{Fe}(\mathrm{II})$ concentration correlation was seen during a regular diel run (not the sunlight influence run) between summer and winter during the May 9 session. The data shows a gradual change from positive correlation to negative correlation during the transition from winter to summer (Figure 7-5). Statistically significant correlation 
Table 7-4: Critical R-squared values based on n pairs of observations for 0.01 and 0.05 significance*. Values modified from (Kachigan, 1982).

\begin{tabular}{ccccc|cccc} 
& 2-tailed & \multicolumn{6}{c|}{ Critical R-squared at ó $=$} & \multicolumn{4}{c}{ R-squared } \\
date & $\mathrm{n}$ & $\mathrm{df}$ & 0.05 & 0.01 & sunlight & temperature & $\mathrm{pH}$ & stage \\
\hline $3-30$ & 21 & 19 & 0.187 & 0.301 & 0.717 & 0.146 & 0.018 & 0.046 \\
$5-9$ & 23 & 21 & 0.171 & 0.277 & 0.008 & 0.435 & 0.017 & 0.419 \\
$6-12$ & 23 & 21 & 0.171 & 0.277 & 0.402 & 0.913 & 0.934 & 0.418 \\
$8-13$ & 25 & 23 & 0.157 & 0.255 & 0.361 & 0.749 & 0.789 & 0.501 \\
$8-15$ loc1 & 8 & 6 & 0.500 & 0.696 & 0.079 & 0.411 & 0.378 & 0.307 \\
$8-15$ loc2 & 9 & 7 & 0.444 & 0.637 & 0.007 & 0.354 & 0.451 &
\end{tabular}

The null hypothesis states that the relationship between $\mathrm{Fe}(\mathrm{Il})$ and the selected parameter is random Gray results indicate acceptance of the null hypothesis at o $=0.05$

*Unshaded areas indicate statistical correlation at $\alpha=0.05$ 

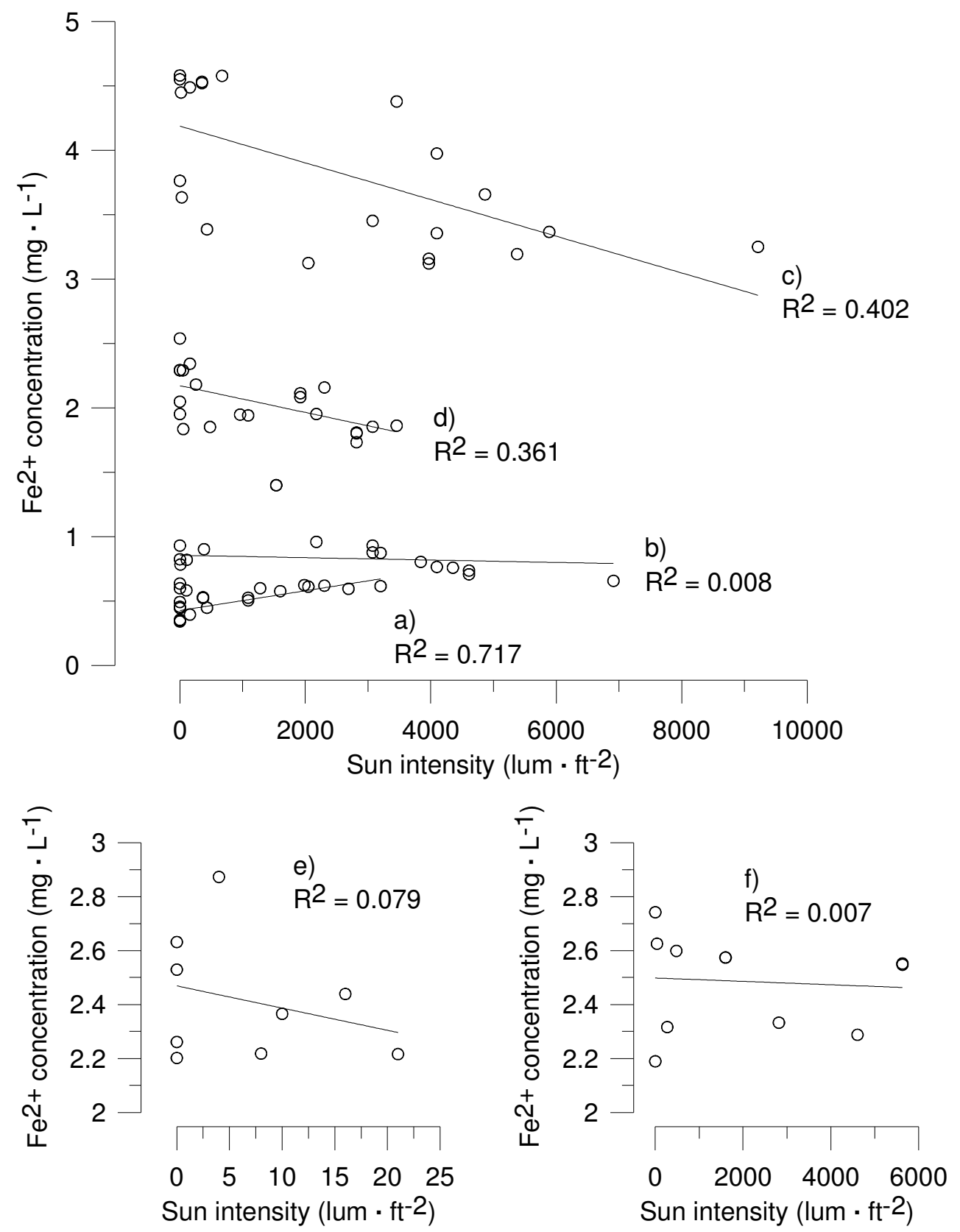

Figure 7-5: Fe(II) and sunlight intensity correlations, 2007.

a: March 30 b: May 9 c: June 12 d: August 13 e: August 15 location 1 f: August 15 location 2 
between sunlight intensity and Fe(II) concentration was accepted at a confidence of $\alpha=$ 0.05 on March 30, June 12 and August 13 and rejected at the same confidence for May 9 and both locations on August 15.

\subsection{Fe(II) and temperature correlation}

Similarly, correlations between Fe(II) concentrations and temperature were calculated (Figure 7-6). Highest R-squared values were seen for the diel runs on June 12 and August 13 respectively and the lowest was seen for March 30. The same gradual shift of positive correlation to negative correlation was seen with the temperature and $\mathrm{Fe}(\mathrm{II})$ correlation analyses. The only positive correlation between temperature and $\mathrm{Fe}(\mathrm{II})$ was seen in the March 30 diel run. May 9 and June 12 displayed negative correlation showing decreasing $\mathrm{Fe}$ (II) with increasing temperature. It is likely that $\mathrm{Fe}(\mathrm{II})$ concentrations themselves were not specifically altered due to temperature, but were more likely influenced by another factor that was temperature dependant. Statistically significant correlation between temperature and $\mathrm{Fe}(\mathrm{II})$ concentration was accepted at a confidence of $\alpha=0.05$ on May 9, June 12, and August 13 and rejected at the same confidence for March 30 and both locations on August 15.

\subsection{Fe(II) and pH correlation}

Correlations between $\mathrm{Fe}(\mathrm{II})$ concentrations and $\mathrm{pH}$ were also calculated for all diel runs (Figure 7-7). The June 12 and August 13 sampling dates show the highest correlation between $\mathrm{pH}$ and Fe(II) concentrations and March 30 and May 9 show the lowest. Again, a difference is seen in correlation between late winter and summer data where in late winter and in transition to summer, there is essentially no correlation between $\mathrm{pH}$ and $\mathrm{Fe}(\mathrm{II})$ values, whereas in summer, there is a positive correlation between $\mathrm{pH}$ and $\mathrm{Fe}(\mathrm{II})$ concentrations where high $\mathrm{pH}$ values correspond to high $\mathrm{Fe}(\mathrm{II})$ concentrations. Statistically significant correlation between $\mathrm{pH}$ and $\mathrm{Fe}(\mathrm{II})$ concentration was accepted at a confidence of $\alpha=0.05$ on June 12, August 13 and August 15 location 2 

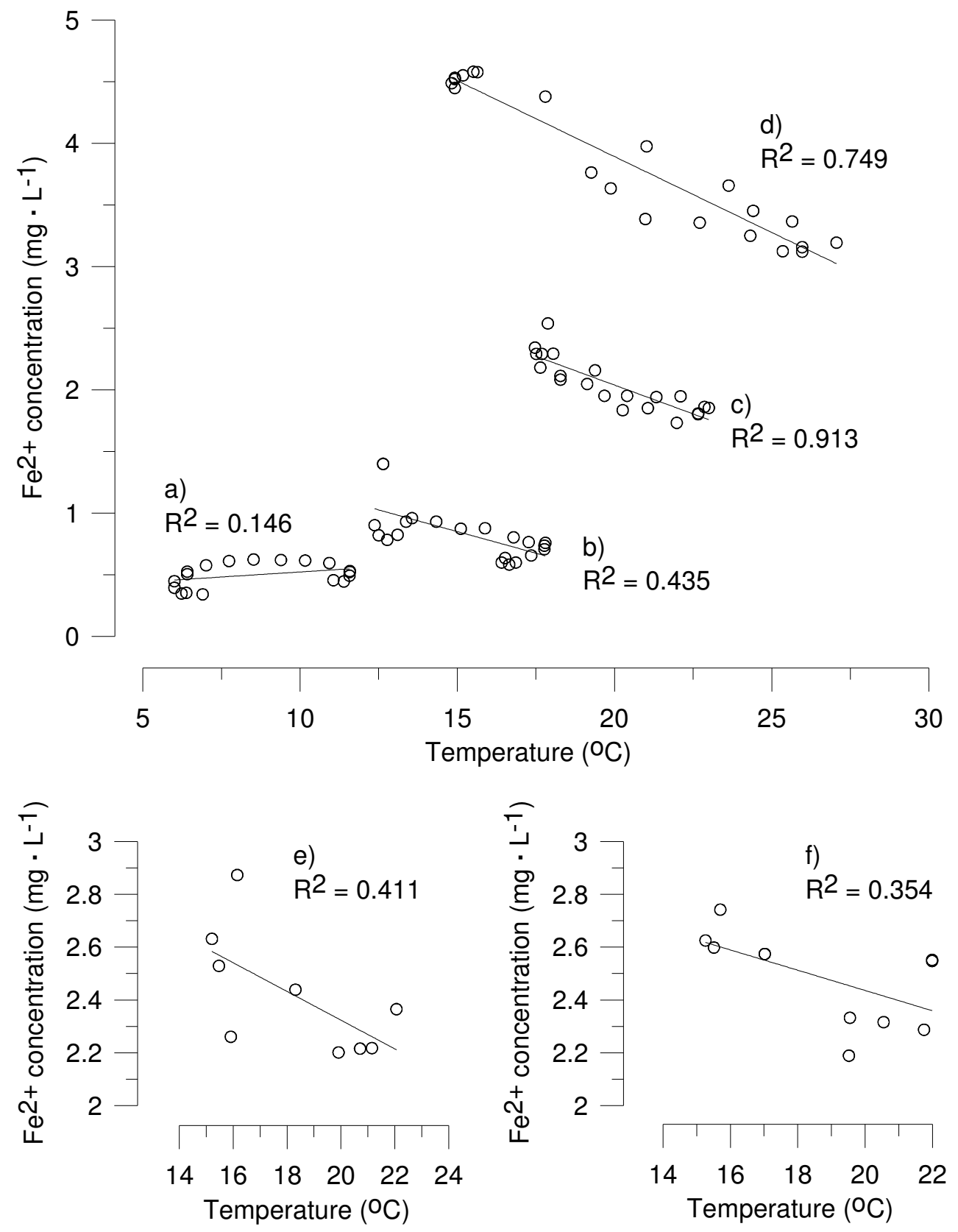

Figure 7-6: $\mathrm{Fe}(\mathrm{II})$ and temperature correlations, 2007.

a: March 30 b: May 9 c: June 12 d: August 13 e: August 15 location 1 f: August 15 location 2 

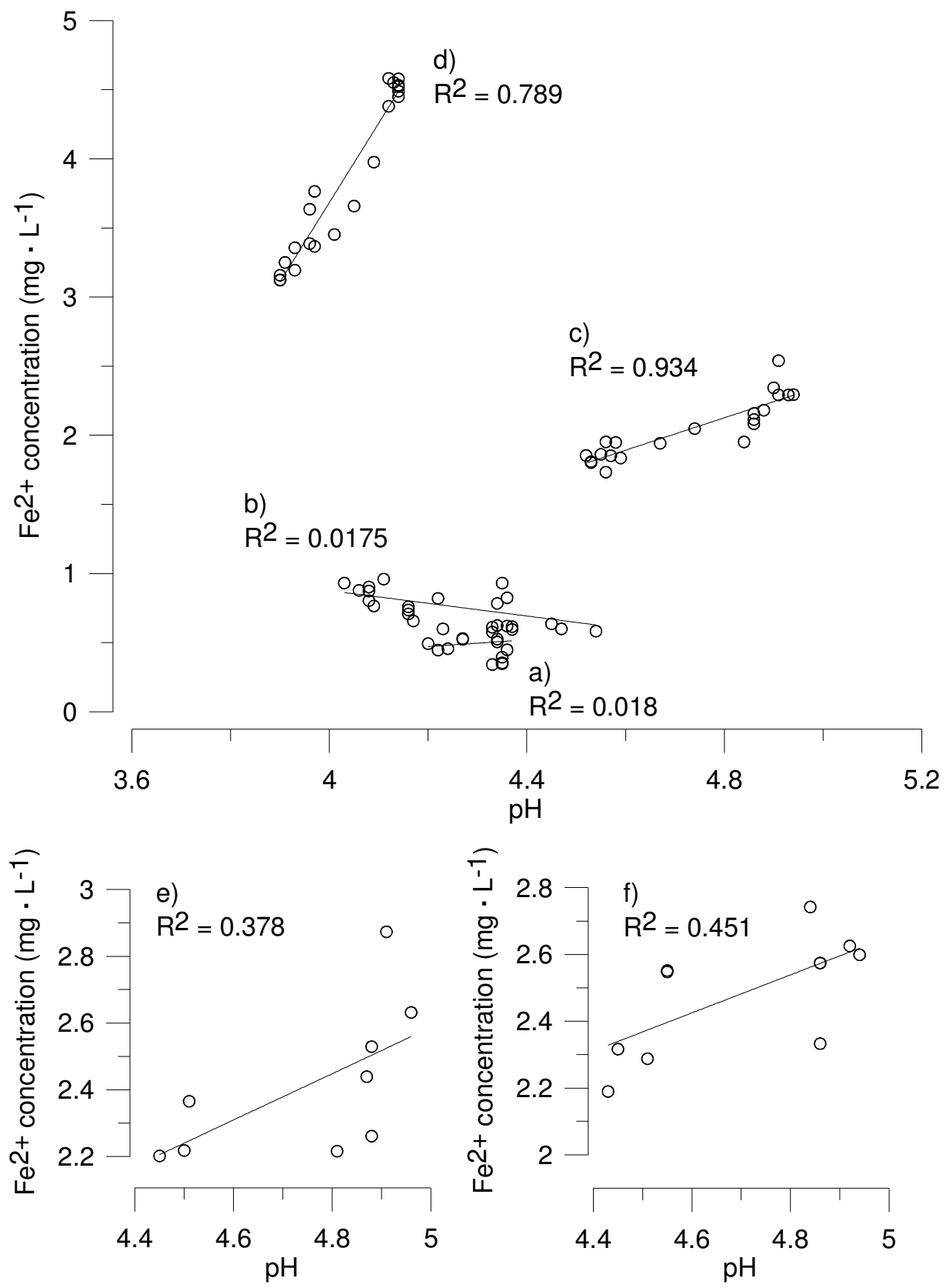

Figure 7-7: $\mathrm{Fe}(\mathrm{II})$ and $\mathrm{pH}$ correlations, 2007.

a: March 30 b: May 9 c: June 12 d: August 13 e: August 15 location 1 f: August 15 location 2 
and was rejected at the same confidence for March 30, May 9 and location 1 on August 15.

\subsection{Fe(II) and P2 water table elevation correlation}

The final correlation analysis compared hourly changes in water table elevation within $\mathrm{P} 2$ to $\mathrm{Fe}(\mathrm{II})$ concentrations (Figure 7-8). The difference in the water elevations is reported as the creek stage minus the P2 stage. Negative values indicate the groundwater level is higher than the creek stage; positive values indicate the opposite relationship.

Correlation analysis performed on $\mathrm{Fe}(\mathrm{II})$ and water table elevations shows a difference between late winter data and summer data. All dates except March 30 show R-squared values between 0.3 and approximately 0.5 and all dates where diel sampling was done in the regular procedure (no sunlight inhibiting tarp) show R-squared values approximately between 0.4 and 0.5 . The August 15 R-squared value may be inaccurately low due to the influence of the sunlight blocking tarp concurrent with regular sampling. Also, correlation shows that for all days except March 30, high water table elevations are coincident with high $\mathrm{Fe}(\mathrm{II})$ values and vice versa. As water table falls, so does $\mathrm{Fe}$ (II) concentration. Correlation analysis performed between water table elevations and $\mathrm{Fe}(\mathrm{II})$ concentrations showed the overall lowest R-squared values of all parameters analyzed. Statistically significant correlation between P2 water table elevation and Fe(II) concentration was accepted at a confidence of $\alpha=0.05$ on May 9, June 12 and August 13 and was rejected at the same confidence for March 30 and location 1 on August 15.

\subsection{Factor analysis}

Factor analysis was also completed for $\mathrm{pH}$, sunlight intensity, differences in water table elevations in $\mathrm{P} 2$ and $\mathrm{PC}(\mathrm{WL})$, temperature, $\mathrm{Fe}(\mathrm{II})$ concentration and total Fe concentrations. $\mathrm{Fe}(\mathrm{III})$ concentration was omitted from the factor analysis as it was derived from other measured Fe concentrations rather than independently measured. The analysis was run with Fe species concentration listed as both $\mathrm{mg} / \mathrm{L}$ concentration and as percent of mean concentration, although results shown below are as $\mathrm{mg} / \mathrm{L}$ since both 


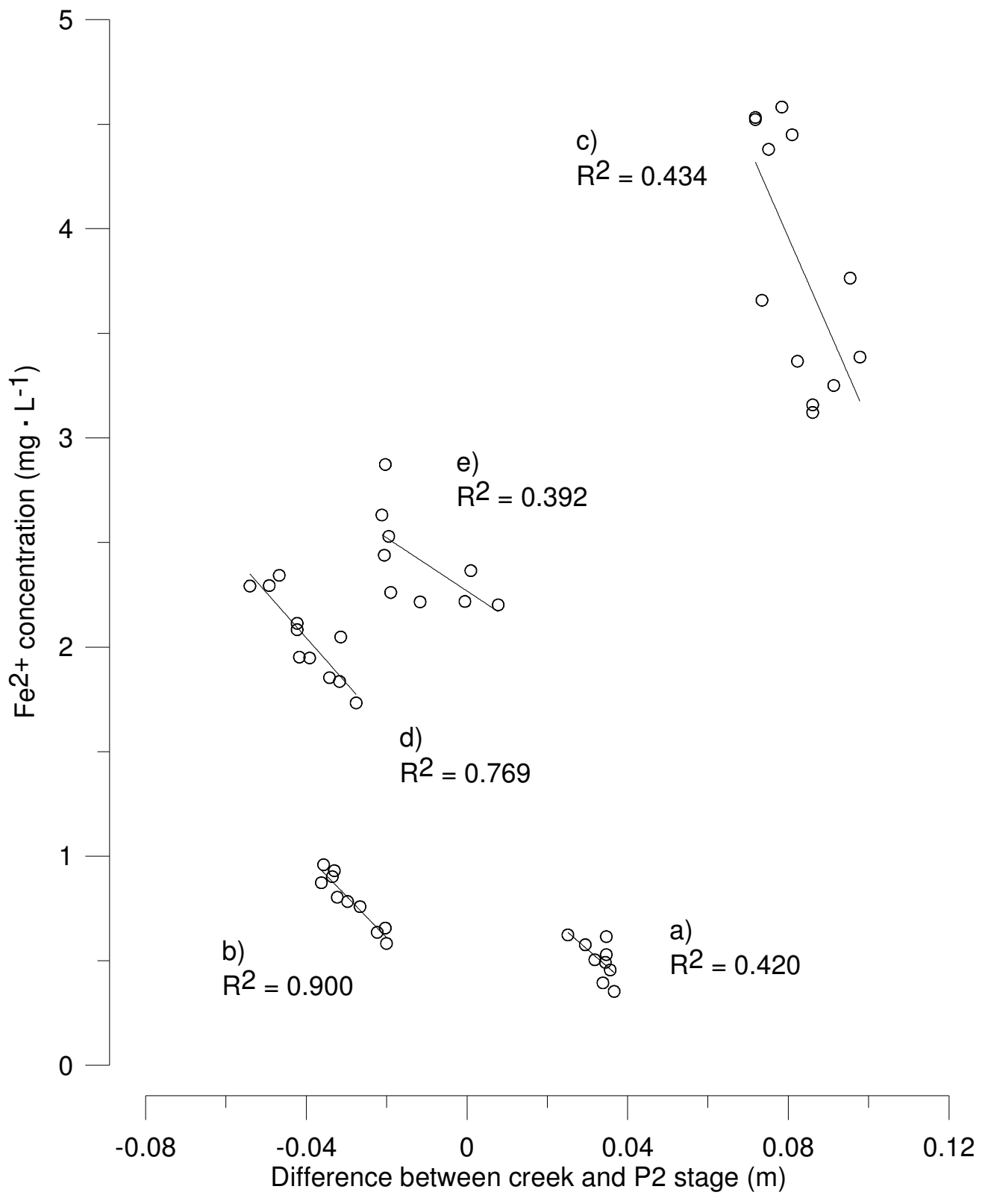

Figure 7-8: Fe(II) and water table elevation correlations, 2007.

a: March 30 b: May 9 c: June 12 d: August 13 e: August 15 location 1 
types of analysis provided similar results. Principal Component Analysis (PCA) was run initially in order to determine the amount of factors needed for factor analysis.

Eigenvalues greater than 1.0 were present in 2 components for each dataset, indicating that factor analysis should be performed using two factors. Analysis was run using an un-rotated correlation matrix.

Factor loadings and sample score patterns showed seasonal variation (Figure 7-9). For March 30, highest inter-correlation was seen between Fe(II), Total Fe, sunlight intensity and temperature. WL did not map closely to any other parameters for March 30. For March 30, factor one (F1) explains $43 \%$ of total variance. Values which scored highly on F1 are likely influenced strongly by sunlight intensity cycles with highest negative loadings on temperature, Fe concentrations and sunlight intensity. High values scored on factor 2 (F2) for March 30 are likely displaying influence by surface watergroundwater interaction, showing highest loads on WL (negative) and Fe(II) concentration (positive). In this instance, the high load on Fe(II) concentration for F2 could be due to a dilution effect since stream stage decreased gradually over the course of sampling. For June 12 and August 13, Fe(II) and total Fe showed highest intercorrelation with $\mathrm{pH}$. Sunlight intensity, difference in P2 and PC water table elevations, and temperature showed very low correlation between themselves or other parameters. For both June 12 and August 13, F1 explains 77\% of the total variance. High loadings on F1 for both dates indicate influence from mine drainage, showing high negative loads for WL, temperature and sunlight intensity, and high positive loads for Fe concentrations and pH. F2 explains $18 \%$ of the variance for June 12 and $12 \%$ of the total variance for August 13. For both of these dates, F2 shows influence from sunlight cycles, with high loads on WL and sunlight intensity. May 9 showed high correlation only between Fe(II) and total Fe, but no other parameters. F1 explains $60 \%$ of the variance for May 9, and is likely indicating effects from surface water-groundwater interactions, showing highest loads on Fe concentrations (positive) and WL (negative). F2 for May 9 explains 33\% of the total variance and may be showing influence from sunlight, with high positive loads on sunlight and temperature and high negative loads on $\mathrm{pH}$. The factor analysis indicates that on March 30, sunlight and temperature are closely related to, and the most likely mechanisms for, Fe cycles. Data from June 12 and August 13 suggest that a likely 


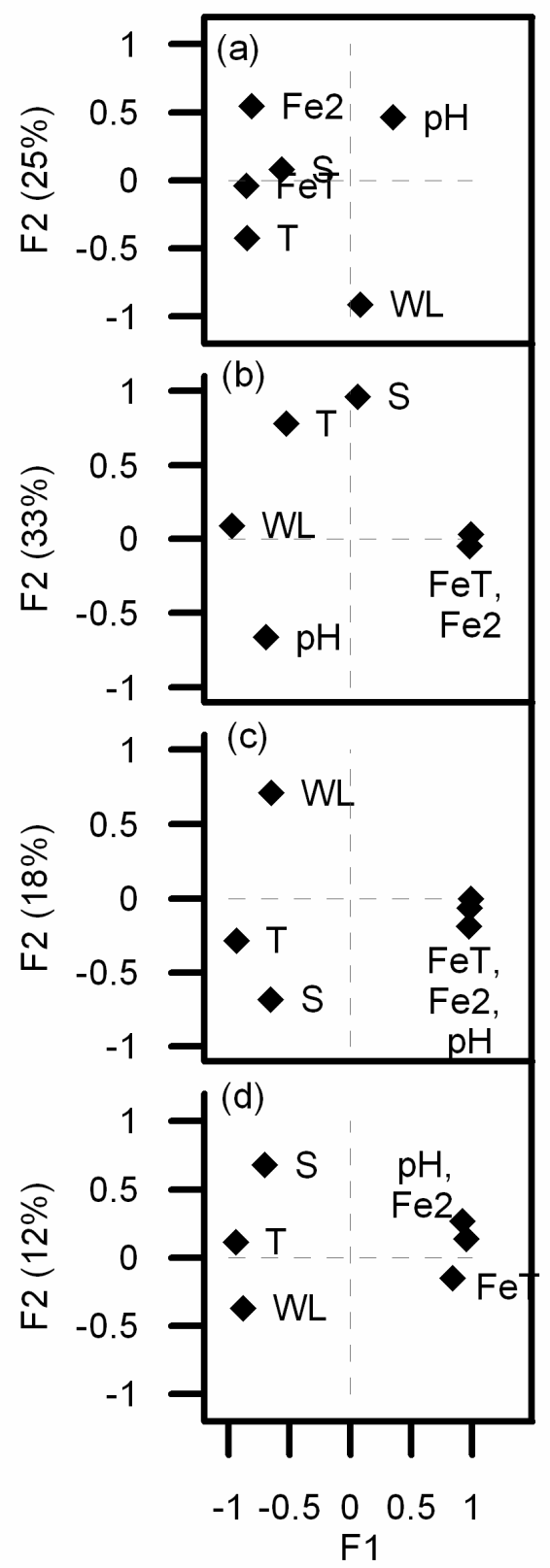

Figure 7-9: Factor analysis for variables from (a) March 30 (F1 explains 43\% of variables), (b) May 9 (F1 61\%), (c) June 12 (F1 77\%) and (d) August 13 (F1 77\%). T for temperature, $\mathrm{S}$ for solar intensity, $\mathrm{Fe} 2$ for $\mathrm{Fe}(\mathrm{II})$ concentration, $\mathrm{FeT}$ for total $\mathrm{Fe}$ concentration and WL for the difference in water level between P2 and Dillan Creek. 
mechanism for their respective months is $\mathrm{pH}$. The lack of correlation between $\mathrm{Fe}$ (II) or total Fe and any other parameters suggests that the May sampling could represent an intermediary month where dominant mechanisms controlling behavior in Dillan Creek are changing.

\subsection{Oxidation-reduction potential}

An Eh-pH diagram for $\mathrm{Fe}-\mathrm{H}_{2} \mathrm{O}$ was created from the thermodynamic data (Drever, 1997; Langmuir, 1997). The $\mathrm{pH}$ data from loggers and dissolved concentrations of $\mathrm{Fe}$ (II) and $\mathrm{Fe}$ (III) for the March 30 sampling date was then plotted on the diagram (Figure 7-10). Eh values were calculated from the iron couple using the formula:

$$
\mathrm{Eh}=\mathrm{E}^{\mathrm{o}}+[(2.303 \mathrm{RT}) / \mathrm{nF}] * \mathrm{LOG}\left[\mathrm{Fe}^{3+}\right] /\left[\mathrm{Fe}^{2+}\right]
$$

where $\mathrm{E}^{\mathrm{o}}$ is the standard electrode potential, $\mathrm{R}$ is the universal gas constant, $\mathrm{T}$ is temperature in Kelvin, $\mathrm{n}$ is the number of electrons transferred, and $\mathrm{F}$ is the Faraday constant. The half reaction used for Eh calculation was:

$$
\mathrm{Fe}^{3+}+\mathrm{e}^{-} \rightarrow \mathrm{Fe}^{2+}
$$

Data from no other sampling dates could be plotted on Eh-pH diagrams since dissolved $\mathrm{Fe}(\mathrm{III})$ was essentially absent during all other sampling events, and therefore Eh could not be estimated. However, the $\mathrm{pH}$ of those samples can be used to estimate the likely placement on the graph, and the associated likely speciation reactions (Figure 710). In this graph, the likely $\mathrm{Fe}$ species undergoing redox reactions during late winter are $\mathrm{Fe}(\mathrm{II}), \mathrm{Fe}(\mathrm{III}), \mathrm{Fe}(\mathrm{OH})^{2+}, \mathrm{Fe}(\mathrm{OH})_{2}{ }^{+}$and $\mathrm{Fe}(\mathrm{OH})_{3}$ amorphous. While this observation is based on the false assumption that the system is in equilibrium, it is still useful in determining likely species of $\mathrm{Fe}$ in winter and summer. The calculated Eh of the system for winter plots at the boundary between $\mathrm{Fe}(\mathrm{II}), \mathrm{Fe}(\mathrm{OH})_{2}{ }^{+}$and $\mathrm{Fe}(\mathrm{OH})_{3}$ amorphous indicating that likely dissolved species are Fe(II) and Fe(III) in the dissolved form $\mathrm{Fe}(\mathrm{OH})_{2}^{+}$.

Sampling performed in Dillan Creek closer to and during summer indicates the lack of dissolved $\mathrm{Fe}$ (III) in the creek. This can be explained by a slight increase in $\mathrm{pH}$ during the summer (from $\sim 4.0$ to $\sim 4.7$ ) causing a slight variation in modeled redox 


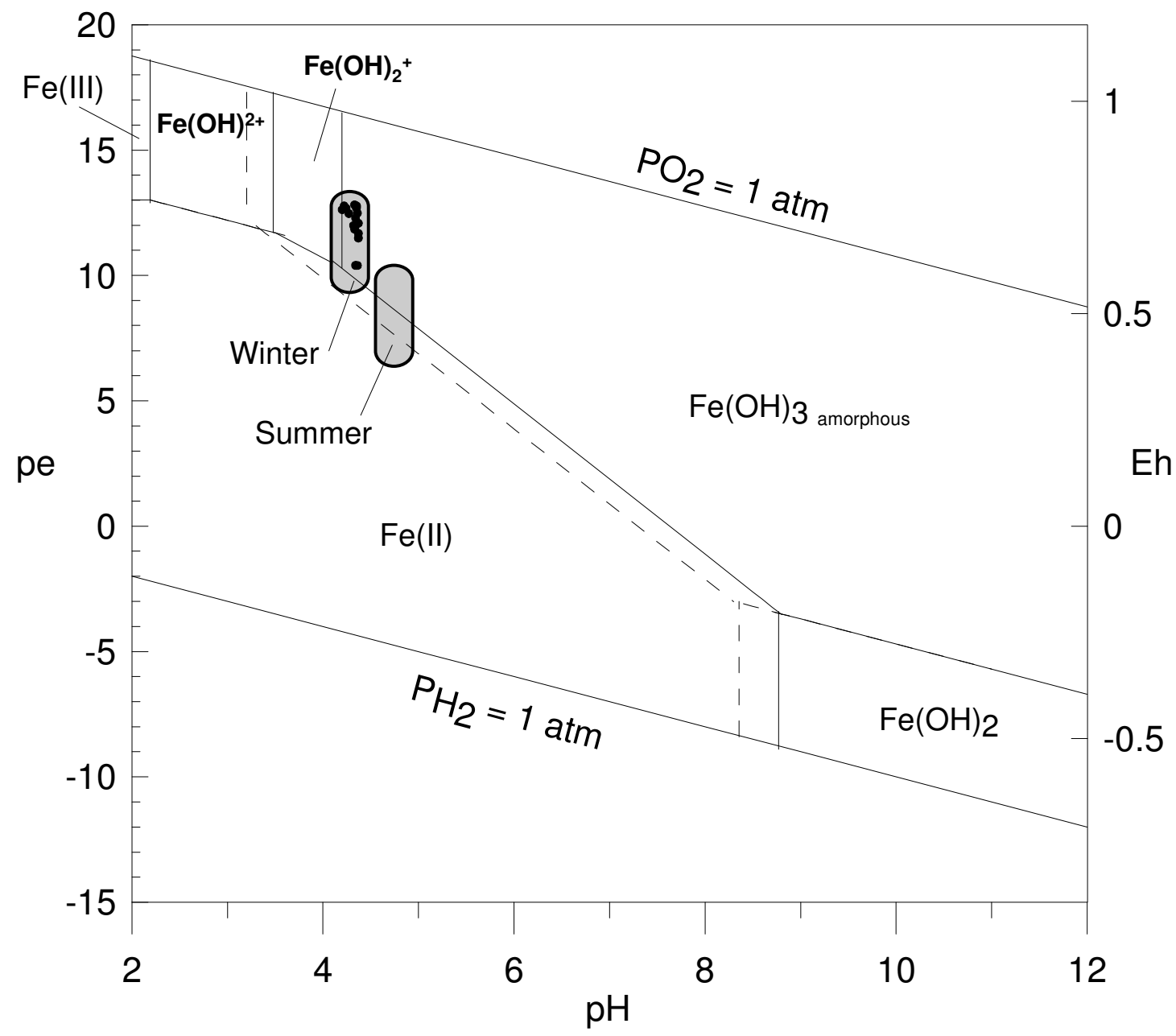

Figure 7-10: Redox conditions for Dillan Creek. Solid lines indicate winter condition boundaries for total Fe activity of $10^{-5}$. Dashed lines indicate summer condition total Fe activities of $10^{-4}$. Boundaries were calculated from Ksp and free energy data in Drever (1997) and Langmuir (1997). Winter points are calculated Eh values based on Fe activities adjusted for ionic strength. Summer range is estimated based on average $\mathrm{pH}$ fluctuations seen in Dillan Creek during summer. $\mathrm{Fe}(\mathrm{OH})_{4}{ }^{-}$and siderite are excluded as they are not stable in the $\mathrm{pH}$ range for Dillan Creek. 
conditions in the creek (Figure 7-10). With a small increase of $\mathrm{pH}$, the likely species involved in redox reactions change to only $\mathrm{Fe}(\mathrm{II})$ and $\mathrm{Fe}(\mathrm{OH})_{3}$ amorphous. Since $\mathrm{Fe}(\mathrm{OH})_{3}$ amorphous is a solid, the only likely dissolved species under these redox conditions is Fe(II), which is what was observed. The $\mathrm{pH}$ of Dillan Creek can be used as a hypothetical model to determine what dissolved species are likely in Dillan Creek during winter and summer settings. According to data in this study, the likely species in late winter are $\mathrm{Fe}(\mathrm{II}), \mathrm{Fe}(\mathrm{OH})_{2}{ }^{+}$, and $\mathrm{Fe}(\mathrm{OH})_{3}$ amorphous, while the likely species in the summer are only $\mathrm{Fe}(\mathrm{II})$ and $\mathrm{Fe}(\mathrm{OH})_{3}$ amorphous. This model explains why dissolved $\mathrm{Fe}(\mathrm{III})$ is present during the March 30 sampling, but not present during all other sampling events.

\subsection{Photoreduction quantum yield}

The amount of $\mathrm{Fe}(\mathrm{II})$ that could have possibly been produced through photoreduction for the March 30 diel run was calculated using an apparent quantum yield (Helz et al., 1994; McKnight et al., 1988; McKnight et al., 2001; Wieder, 1994):

$$
\mathrm{Y}=\left(\mathrm{H}^{*} \mathrm{~A}\right) / \mathrm{Q}
$$

where $\mathrm{Y}$ is $\mathrm{Fe}(\mathrm{II})$ yield over the entire wetland, $\mathrm{H}$ is moles of $\mathrm{Fe}(\mathrm{II})$ produced per mol of $\mathrm{UV}$ radiation, and Q is discharge in L/day. An estimated average value for incident UVradiation for a midsummer day at mid-latitudes of $60 \mathrm{~mol} \mathrm{~m}^{-2}$ day $^{-1}$ was used since datalogger sunlight measurements are suspect (Wieder, 1994). An apparent quantum yield of 0.14 moles of $\mathrm{Fe}(\mathrm{II})$ produced per mol of UV-radiation assuming $\mathrm{Fe}(\mathrm{OH})^{2+}$ as a $\mathrm{Fe}(\mathrm{III})$ source was used in order to provide an upper limit to $\mathrm{Fe}(\mathrm{III})$ photoreduction. Other Fe(III) species may react as well, but with less quantum yield per mol. Minimum yield would be from goethite $(\alpha-\mathrm{FeOOH})$ at $(0.19-2.9) \times 10^{-4}$ mols $\mathrm{Fe}(\mathrm{II})$ produced per mol incident UV radiation. The length of the sunlit portion of the stream was multiplied by its average width for a total stream area of $480 \mathrm{~m}^{2}$. Average stage over all diel runs was used in conjunction with the created rating curve to get an average discharge of $0.032 \mathrm{~m}^{3} / \mathrm{sec}$ for all diel runs. Assuming a hydroxide radical as the ligand source for $\mathrm{Fe}(\mathrm{III})$, the calculated yield under these parameters is at a maximum of $2.67 \mathrm{mg} / \mathrm{L} \mathrm{Fe}$ (II) produced over the course of a day through photoreduction. This amount of increase 
should not only be noticeable, but should also dominate other processes if $\mathrm{Fe}(\mathrm{OH})^{2+}$ accounts for most Fe(III) present in the system. Because of this assumption, the estimate provided here is likely to be high. Using an intermediary $\mathrm{Fe}(\mathrm{III})$ species of $\mathrm{Fe}_{2}(\mathrm{OH})_{2}{ }^{4+}$ for example would provide a value of $0.13 \mathrm{mg} / \mathrm{L} \mathrm{Fe}(\mathrm{II})$ produced from $\mathrm{Fe}(\mathrm{III})$ over the course of a day. Amorphous hydrous Fe(III) oxides at an approximate yield of $10^{-4}$ moles $\mathrm{Fe}(\mathrm{II})$ produced per mol of UV radiation (Wieder, 1994) would show an increase in $\mathrm{Fe}$ (II) concentrations from photoreduction of $0.036 \mathrm{mg} / \mathrm{L}$. The high variability of $\mathrm{Fe}(\mathrm{II})$ production according to specific $\mathrm{Fe}$ (III) species causes uncertainty in the $\mathrm{Fe}$ (II) change expected, although it also shows that photoreduction of Fe(III) has the potential to be a driving factor in Fe cycles.

\subsection{August 15 location 1 and location 2}

The August 15 diel run using plastic to inhibit sunlight reactions in the creek may serve to show that sunlight does play an important role in the cycling of iron concentrations even if it is not the driving mechanism. Comparison of data from the sunlit portion of the creek to data from the covered portion of the creek shows a slight difference (Figure 6-3e-f). The timing of maximum concentrations of iron is different at the two locations when it is expected that they be the same. While comparison of these two locations shows that blocking sunlight may cause a difference in timing, the covered section actually better matches all data from previous studies better than the uncovered section. It is possible that the discrepancy between the two locations for this study may be caused by subtle local differences between the two locations. Sampling at location 2 was not performed during any studies other than August 15 so there is no data with which to compare location 2. Location 1 is located where all other sampling was performed on all previous sampling days, so rather than drawing conclusions by comparison of location 1 to location 2, it seems more relevant to compare location 1 from August 15 to the same location on all other sampling days. Location 1 from the August 15 sampling session shows a similar trend to the same location on all previous sampling days except March 30. The trend seen at location 1 indicates that photoreduction is not controlling iron fluctuation, which matches previous non-winter cycles. Even though photoreduction is 
not the driving mechanism for cycles, it is still likely occurring, which would serve to offset whatever process is responsible for the cycles. If this is the case, then blocking the sunlight at location 1 should have made the difference in maximum and minimum concentrations of $\mathrm{Fe}(\mathrm{II})$ greater than the difference at location 2. Location 1 shows a $23 \%$ drop in Fe(II) concentrations over the course of the sampling, while location 2 only shows a $20 \%$ drop in $\mathrm{Fe}(\mathrm{II})$ concentration. This indicates that photoreduction is still occurring, although the results of photoreduction are subdued against the mechanism responsible for the larger diel signal. 


\subsection{Discussion}

\subsection{Photosynthesis}

While the possibility that changes in iron concentration are responsible for $\mathrm{pH}$ fluctuation has been explored, it is also possible that changes in $\mathrm{pH}$ are affecting iron concentrations. Thus, the mechanism controlling cycles in $\mathrm{pH}$ would be indirectly controlling iron cycles as well. Cycles in $\mathrm{pH}$ are typically accounted for by photosynthetic uptake of $\mathrm{CO}_{2}$ during the day and a lack thereof during the night. These changes in the uptake of $\mathrm{CO}_{2}$ cause $\mathrm{pH}$ increases during the day, and decreases at night. This seems possible under the Eh setting the data falls under (Figure 7-10), but examination of the nature of cycling reveals that $\mathrm{pH}$ changes are not likely the dominant mechanism controlling iron. All sampling days showed an overall decrease in $\mathrm{pH}$ during the day and an increase at night, opposed to what would be expected if $\mathrm{pH}$ cycles were caused by photosynthetic processes. Furthermore, according to the Eh-pH diagram, under a stable Eh setting, an increase in $\mathrm{pH}$ could lead to a decrease in dissolved Fe(III) as $\mathrm{Fe}(\mathrm{III})$ ions change into solid $\mathrm{Fe}(\mathrm{OH})_{3}$ amorphous. $\mathrm{Fe}(\mathrm{II})$ concentrations actually decrease during the day on all days except March 30, which is the opposite of what is expected if changes in $\mathrm{pH}$ were controlling $\mathrm{Fe}(\mathrm{II})$ cycling. While a decrease in $\mathrm{pH}$ during the afternoon of March 30 is in phase with a slight increase in $\mathrm{Fe}(\mathrm{III})$ concentrations, $\mathrm{pH}$ changes can not explain the behavior of Fe(II) concentrations, which increase more likely due to photoreduction than $\mathrm{pH}$ changes. This suggests that changes in $\mathrm{pH}$ are not the controlling mechanism for iron fluctuation in Dillan Creek. Because of this, the high correlation between Fe species and $\mathrm{pH}$ seen in the factor analysis for June 12 and August 13 is likely due to Fe species controlling $\mathrm{pH}$ in Dillan Creek rather than $\mathrm{pH}$ controlling $\mathrm{Fe}$ species. 


\subsection{Photoreduction}

Of all the diel sampling sessions, the only one consistent with diel cycling of iron due to photoreduction was the March 30 session. Trends in iron concentration during March show an increase in $\mathrm{Fe}(\mathrm{II})$ concentrations and a subsequent decrease in $\mathrm{Fe}(\mathrm{III})$ concentrations coincident with the gradual increase in sunlight intensity until 13:00. At this point sunlight intensity is at its highest and is concurrent with the highest rate of Fe(II) production and Fe(III) consumption (Gammons et al., 2005a). The significantly higher concentrations of $\mathrm{Fe}(\mathrm{II})$ than $\mathrm{Fe}(\mathrm{III})$ indicate that most $\mathrm{Fe}(\mathrm{III})$ consumed through photoreduction was present as solid HFO rather than dissolved ions (Figure 7-10). Total Fe increased a small amount during the sampling interval as well, either due to the photoreduction of precipitated Fe(III) as well as dissolved $\mathrm{Fe}(\mathrm{III})$, or due to the small decrease in creek stage over the sampling period. The factor analysis also supports the likelihood of photoreduction as the dominant mechanism for March 30. A high correlation was calculated between sunlight intensity, temperature and Fe species for March 30, but no other sampling days. For all other sampling days, correlation was highest between Fe species and pH. Quantum yield analysis also demonstrated that depending on specific Fe(III) species present, photoreduction has the potential to cause noticeable changes in Fe species chemistry within Dillan Creek.

All other cycles were inconsistent with photoreduction-driven Fe cycles. Maximum concentrations of Fe(II) observed in all other diel cycles show a maximum concentration of $\mathrm{Fe}(\mathrm{II})$ several hours earlier than would be expected for a cycle caused by iron photoreduction.

While photoreduction was likely occurring on all sampling dates, the effects on iron concentrations were likely dominated by a different controlling mechanism. According to percent changes in $\mathrm{Fe}(\mathrm{II})$ concentrations, variability decreased during the transition from winter to summer (Table 7-1). It was shown that late winter cycles were controlled by photoreduction. All sampling dates after March 30 indicate a different mechanism likely controlling cycles. This mechanism began between March 30 and May 9. Because of the two offsetting mechanisms, percent changes between maximum and minimum concentrations decrease (Table 7-1). This percent change continues to 
decrease with the progression into summer, presumably due to the increase in sunlight intensity as summer approaches. As sunlight intensity increases, so does photoreduction. While photoreduction does not control the cycling of iron, it does subdue the effects of the controlling mechanism.

Diel studies performed in Colorado streams have shown increases in $\mathrm{Fe}(\mathrm{II})$ coincident with increases in sunlight intensities (Gammons et al., 2005a; McKnight et al., 1988) (Figure 8-1). Decreases in Fe(II) occur during the afternoon and are coincident with decreases in sunlight intensity. Work performed in Rocky Mountain streams indicate that photoreduction coupled with solar cycles is the dominant driving mechanism controlling Fe species fluctuations. Cycles observed from these streams match well with data from late winter cycles observed in Dillan Creek strengthening the likelihood that winter cycles in Dillan Creek are controlled by photoreduction (Figure 8-1). Differences in iron cycles between rocky mountain streams and Dillan Creek during other times of the year are likely due to the difference in hydrologic and biologic setting.

\subsection{Evapotranspiration}

Cycles in iron seen in all sampling sessions other than March 30 indicate a mechanism other than photoreduction. One possible mechanism is evapotranspirational release of iron-rich groundwater into the creek at night and subsequent pumping out during the day. Since Fe(II) concentrations in Dillan Creek are typically much lower (0.6 - $4.5 \mathrm{mg} / \mathrm{L})$ than in the surrounding ground water $(\sim 30 \mathrm{mg} / \mathrm{L})$, pumping between the two should cause a cyclic variation in $\mathrm{Fe}(\mathrm{II})$ concentrations in Dillan Creek. In winter, evapotranspiration should be nonexistent and diel variability in water table elevation should not be visible during extended periods without precipitation. During summer, after plant life has returned to the meadow, evapotranspiration increases, which should be visible as a diel pattern in water table elevations.

Only one sampling episode of the five showed a change in highest water table elevation between creek stage and groundwater. On all other sampling days, creek stage was either higher or lower than groundwater elevation over the entire sampling episode. If water elevation is higher in the groundwater than in the creek at all times during the 


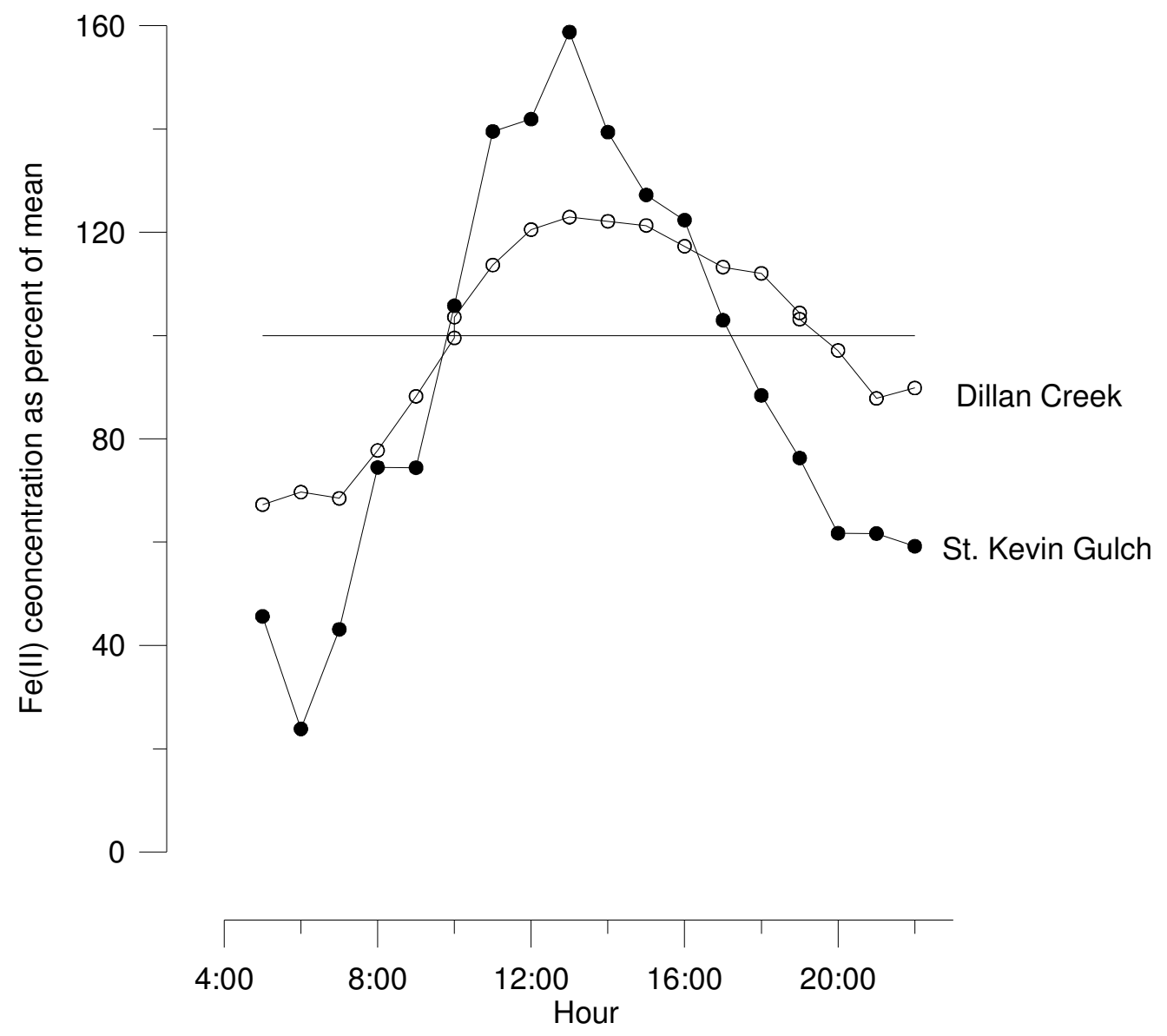

Figure 8-1: Diel cycles in dissolved Fe(II) seen in St. Kevin Gulch, CO compared to data from Dillan Creek on March 30, 2007 (McKnight et al., 1988). 
sampling episode, water from the groundwater should be continuously flowing into Dillan Creek. Since the groundwater has a higher concentration of total Fe then the creek water, a constant in-flow of water could cause a diel signal in total Fe concentrations related to the rate at which flow enters the creek from the groundwater. The rate of inflow should be controlled by difference in groundwater elevation and creek stage. Therefore, if evapotranspiration causes a decrease in groundwater elevation during the day, there should be a subsequent decrease in Fe(II) concentration in Dillan Creek during the day. At night, when evapotranspiration ceases, groundwater elevation should rise, causing higher input to Dillan Creek and an increase in Fe(II) and total Fe concentrations. If, however, the creek stage is always higher than the groundwater elevation, Dillan Creek would always be losing its water into the groundwater. While a diel trend could still be seen in rate of loss caused by evapotranspiration, this should make little impact on total $\mathrm{Fe}$ and $\mathrm{Fe}(\mathrm{II})$ concentrations in Dillan Creek.

Water elevation in the riparian zone was higher than creek stage on all sampling days except March 30 and June 12. Since creek stage was always higher than groundwater elevation on these two days, evapotranspiration should not have caused a decrease in Fe(II) during the day on either of these sampling days. The March 30 sampling session was the only day in this study that showed no decrease in $\mathrm{Fe}$ (II) concentrations before 12:00. It was also the only day in the study where no evapotranspirational driven cycling of groundwater elevations was noted. However, the June 12 sampling episode did show a decrease in Fe(II) during the day, starting at 10:00 while there was no decrease in water table elevation until 12:00. According to the relative elevations of the creek and the groundwater, Dillan Creek should have been losing water into the ground over the entire diel sampling session. Therefore, the decrease in $\mathrm{Fe}(\mathrm{II})$ concentration can not be tied to a decrease in input from iron rich groundwater caused by evapotranspiration. The fact that the timing of the diel concentrations of iron from this sampling date matches the timing of diel iron concentrations on all other days except March 30 indicates that a process other than evapotranspiration is causing the diel cycle in iron concentrations in Dillan Creek. Evapotranspirational driven cycling of Fe concentrations should show an immediate decrease associated with loss of creek water caused by decrease in groundwater 
elevation. Since decreases in Fe(II) concentrations were out of phase with decreases in groundwater elevations, it is unlikely that evapotranspirational pumping is the dominant mechanism causing cycles in Dillan Creek. Factor analysis supports this conclusion since difference between PC and P2 water tables did not correlate well with any other parameter for any diel sampling day.

Changes in mixing ratio according to diel stream-flow alteration are commonly mentioned in literature (Gammons et al., 2005b; Nimick et al., 2003; Nimick et al., 2005; Roberts and Wilch, 2005), but typically discounted. Studies performed in Montana and Idaho indicate that diel stream-flow changes associated with evapotranspirational pumping were out of phase with diel changes in trace metal concentrations, indicating that ET is not responsible for cycling of metals in that setting (Nimick et al., 2003; Nimick et al., 2005). Evapotranspirational pumping was discounted in a separate study from Montana due to a lack of observed diel cycling of most metal loads while a clear diel signal in stream-flow was witnessed due to loss of water through ET. Evapotranspirational pumping is unlikely for Dillan Creek due the lack of Fe cycles and groundwater losses being in phase with each other. While ET may be unlikely, it can't be discounted due to the need for more data and modeling. While ET may not cause a significant enough change in water table elevations to reverse flow gradients, it may cause significant changes in mixing ratios between the groundwater and the channel water.

\subsection{Microbial activity}

Research done on constructed wetlands has indicated the possibility that acidophilic bacteria may cause the diel iron variability seen in some AMD impacted areas. Common iron oxidizing bacteria in AMD impacted areas are Acidithiobacillus ferroxidans and Leptospirillum ferrooxidans (Konhauser, 2006) as well as members of the genera Gallionella, Leptothrix and Marinobacter (Weber et al., 2006). These bacteria utilize $\mathrm{Fe}$ (II) oxidation and $\mathrm{Fe}$ (III) reduction processes to produce ATP. The energy obtained through the oxidation of $1 \mathrm{~mol} F($ III), however, is barely enough for the production of $1 \mathrm{~mol}$ of ATP (Konhauser, 2006). Therefore, acidophilic bacteria must 
oxidize a high amount of iron in order to survive, causing small populations of bacteria to have the potential to oxidize high amounts of $\mathrm{Fe}(\mathrm{II})$. Also, due to the stability of $\mathrm{Fe}(\mathrm{II})$ in low presence of oxygen, the oxidation of $\mathrm{Fe}(\mathrm{II})$ is most active in anoxic environments. $A$. ferrooxidans uses the oxidation of $\mathrm{Fe}$ (II) as a method by which to accept a proton in the overall reaction:

$$
26 \mathrm{Fe}^{2+}+0.5 \mathrm{O}_{2}+6 \mathrm{CO}_{2}+29 \mathrm{H}^{+} \rightarrow \mathrm{C}_{6} \mathrm{H}_{12} \mathrm{O}_{6}+26 \mathrm{Fe}^{3+}+7 \mathrm{H}_{2} \mathrm{O}
$$

This proton is used in chemiosmosis so that a neutral $\mathrm{pH}$ may be retained in the cytoplasm, which induces a voltage gradient between the bacteria and the low $\mathrm{pH}$ water known as the proton motive force (pmf) which drives ATP production (Konhauser, 2006). A diverse array of microorganisms have also been shown to utilize Fe(III) reduction as a process for respiration. Microbial reduction of $\mathrm{Fe}(\mathrm{III})$ has been shown to occur even in the lack of aqueous Fe(III), when only insoluble Fe(III) in the form of poorly crystalline Fe(III) oxides such as ferrihydrite or crystalline oxides such as goethite, hematite and magnetite are available (Weber et al., 2006).

Oxidation of $\mathrm{Fe}(\mathrm{II})$ has also been tied to photoautotrophs which utilize light energy to fix $\mathrm{CO}_{2}$ into biomass via the following reaction (Weber et al., 2006):

$$
\mathrm{HCO}_{3}{ }^{-}+4 \mathrm{Fe}^{2+}+10 \mathrm{H}_{2} \mathrm{O} \rightarrow \mathrm{CH}_{2} \mathrm{O}+4 \mathrm{Fe}(\mathrm{OH})_{3}+7 \mathrm{H}^{+}
$$

This mechanism would explain the decrease in Fe(II) coincident with sunlight intensity increase during spring and summer sampling. Subsequent increases in Fe(II) are seen at night when bacterial reduction proceeds in the absence of sunlight as a driver for oxidation. These reduction reactions likely use insoluble Fe(III) hydroxides as soluble $\mathrm{Fe}(\mathrm{III})$ was absent at the witnessed $\mathrm{pH}$ range. This type of cycling was seen on all sampling dates excluding March 30. It is likely that the March 30 cycle was influenced by a separate mechanism due to decreased activity of bacteria during the winter.

Correlations calculated between Fe(II) concentrations and sunlight intensity reflect the likelihood of this mechanism. For the March 30 date, a positive correlation was seen between Fe(II) and sunlight intensity. For all other sessions, an inverse correlation was seen with increased Fe(II) at night rather than during the day. Correlations calculated between temperature and Fe(II) were likely indicative of the same process due to the drop in temperature at night. Low Fe(II) concentrations were 
correlated with higher temperatures due to high temperatures being associated with daylight conditions.

Data from constructed wetlands in the Earle C. Clements Job Corps Satellite Facility in Greenville, Kentucky indicate the likelihood of biologic activity as a driving mechanism for diel cycling of dissolved Fe species (Wieder, 1994). Data from (Wieder, 1994) were collected during mid May and mid July, 1991, and 1990 respectively. In order to minimize differences due to seasonal effects, Wieder's July 17 data were compared to the May 9 and June 12 data from this study (Figure 8-2). While cycles in dissolved Fe(II) concentrations were similar for both the Wieder data and the data from this study, total Fe and Fe(III) cycles were not. In the Wieder study, cycling of both $\mathrm{Fe}(\mathrm{III})$ and total Fe occurred, but data from this study suggests that while cycles in total Fe are present, all iron present is in the $\mathrm{Fe}(\mathrm{II})$ form causing a lack of a $\mathrm{Fe}(\mathrm{III})$ diel signal. Cycles in Greenville, KY were explained by anaerobic bacterial reduction at night. These cycles were controlled by diel availability in DO, whereas in Dillan creek, cycles in $\mathrm{Fe}$ (II) concentration are tentatively explained by a change from $\mathrm{Fe}$ (II) oxidation in the presence of sunlight to net $\mathrm{Fe}$ (III) reduction at night in the absence of sunlight.

\subsection{Mechanism competition}

It is likely that photoreduction influences Fe concentrations year round, although this process may be overwhelmed by the magnitude of a separate mechanism during some seasons. Photoreduction was the likely dominant mechanism in only one diel run performed (March 30). The second likely mechanism for diel Fe cycles is bacterial influence causing oxidation of $\mathrm{Fe}$ (II) during the day and reduction of $\mathrm{Fe}$ (III) at night. This mechanism seems to dominate the system in Dillan Creek for most of the year and is indicated by a decrease of Fe(II) during the day possibly due to increased sunlight availability as a driver for oxidation. The competition between photoreduction and bacterial processes may be seen through comparison of seasonal percent variation over the course of one cycle. In the winter, where photoreduction proceeds without the interference of bacterial influences, percent difference between maximum and minimum 


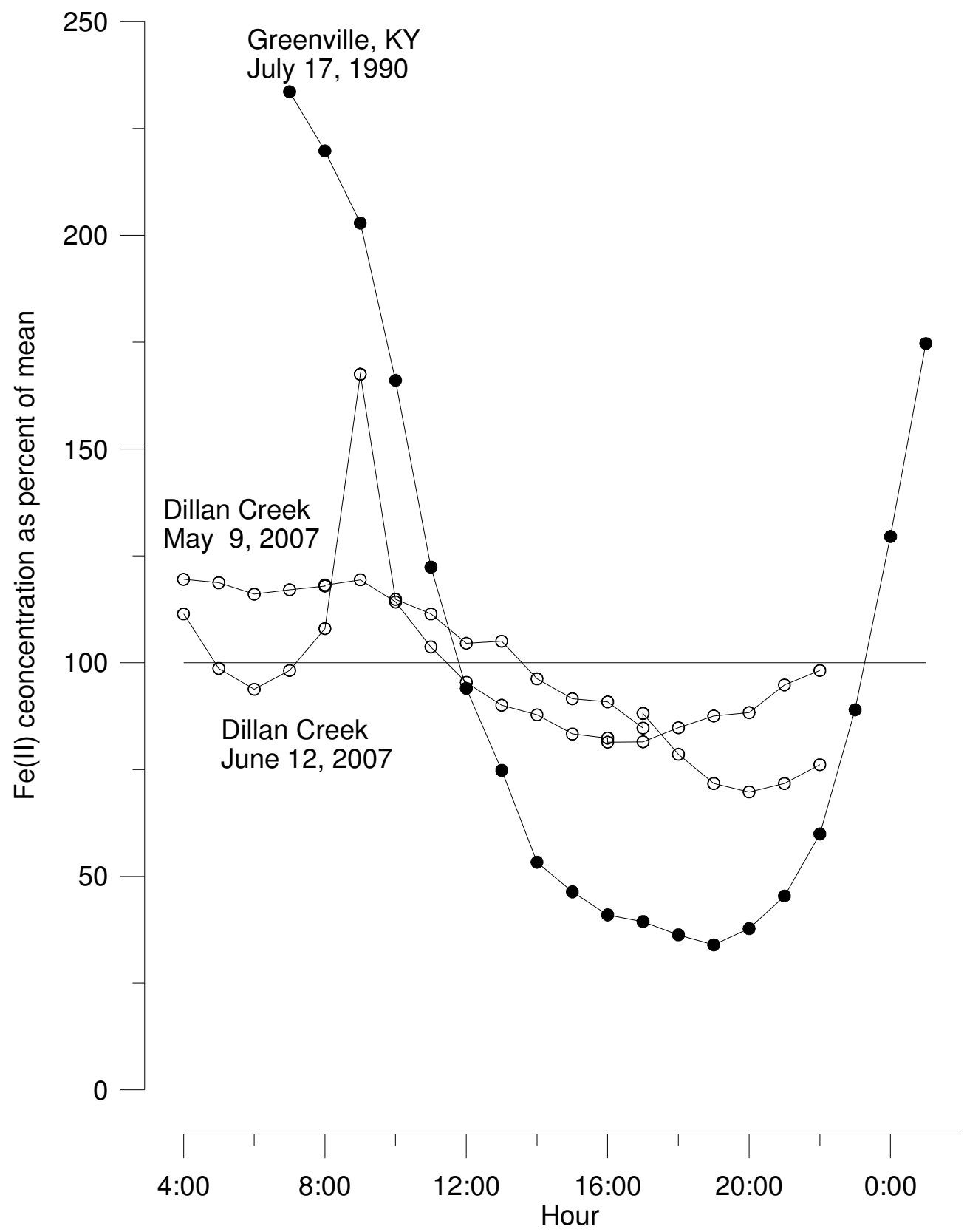

Figure 8-2: Comparison of Fe(II) data from Dillan Creek to Fe(II) data from a Sphagnum peat wetland in Greenville, KY. Modified from Wieder (1994). 
$\mathrm{Fe}(\mathrm{II})$ concentrations is highest. Once bacterial influence dominates the system, percent difference decreases due to the competition between the two mechanisms. This percent difference continues to decrease as summer approaches indicating increased competition between photoreduction and bacterial influence as sunlight intensity increases during the onset of summer. Further complications arise from the differing hydrologic setting during winter and summer. While hydrologic cycles may not be a primary cause of diel metal cycle timing, they may influence the concentration minima and maxima (Nimick et al., 2005). The general increase in discharge of Dillan Creek during the winter may lead to a dilutional effect and lower Fe concentrations; however, seasonal changes in discharge can not explain the variation in timing of cycles. 


\subsection{Conclusions}

In this study, diel fluctuations of dissolved Fe species were confirmed in Dillan Creek. Difference between maximum and minimum concentration of dissolved Fe(II) varied by season, but was never less than $20 \%$. While cycles were witnessed during each sampling episode, the nature of the cycles varied according to season. During late winter, cycles in $\mathrm{Fe}(\mathrm{II})$ and $\mathrm{Fe}(\mathrm{III})$ were witnessed simultaneously and were likely driven by photoreduction as timing of cycles were in phase with sunlight intensity cycles. In all other sampling episodes, from May to August, dissolved Fe cycles persisted, but changed in nature (Figure 9-1). Cycles for all sampling except March showed decreases in Fe(II) concentration during the morning with no increase until late afternoon or evening. These cycles must have a different controlling mechanism than the March cycles due to the opposite trend in Fe(II) concentrations. Also, Fe(III) concentrations showed no diel variability from May through August indicating that all dissolved $\mathrm{Fe}$ is present in the Fe(II) species. Several mechanisms could cause the cycles observed during May through August, although bacterial influence was the most likely.

Considered mechanisms used to explain the diel cycles in Fe witnessed in Dillan Creek were photoreduction, bacterial influence, and variable mixing rates between the creek water and the groundwater driven by ET cycles. The least likely mechanism in this study was the cycle induced by ET. While cycles in groundwater elevation were seen, likely caused by ET cycles, it was concluded that these groundwater cycles were not correlated to Fe cycles witnessed in stream. If cycles in groundwater elevation driven by ET were causing diel cycles in Fe, they should be in phase, which was not the case. Furthermore, diel cycles in Fe persist when creek stage is lower than groundwater elevation. If diel cycles in Fe were caused by ET in the riparian zone, they would cease when creek stage is higher than groundwater elevation if these conditions apply over the entire duration of the cycle.

To further study the impacts of sunlight on Dillan Creek, the final diel run was conducted at the in-flow and out-flow of a 30.5 meter tarp covering Dillan Creek on August 15. While this tarp did not change the nature of the diel signal in Fe species, it 


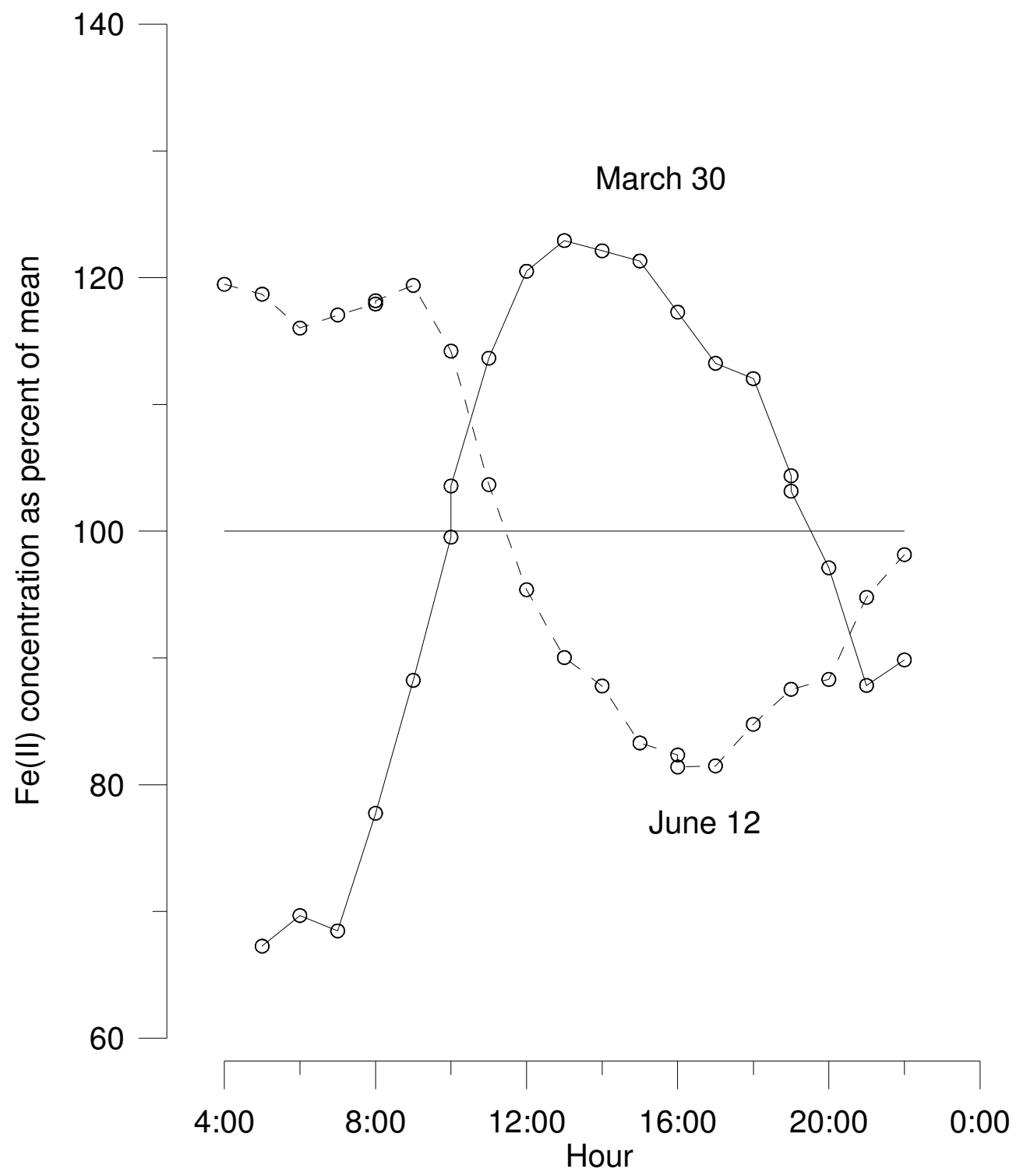

Figure 9-1: March 30 diel Fe(II) cycle compared to June 12 diel Fe(II) cycle. The June 12 cycle is representative of all diel Fe(II) cycles for this study with the exception of March 30. 
did show a difference in the magnitude of cycles. At the uncovered location, where both sunlight and bacterial mechanisms were operating, there was a smaller variation between maximum and minimum $\mathrm{Fe}$ (II) concentrations. At the covered location, the difference was slightly greater. While the nature of the diel cycling did not change, this strengthens the argument that photoreduction and bacterially mediated reactions are competing in Dillan Creek since retardation of photoreduction caused an increase in magnitude of cycling.

While specific questions about the presence and controls of Dillan Creek were answered for this study, several questions remain unanswered. Further work should incorporate additional analyses to determine more specifically the possibility and impacts of sorption and precipitation mechanisms. Those data would also be useful in determining the specific forms of iron. Digestion of sediment samples would also help to better define the environment. A diel cycle similar to the one performed on August 15 should be conducted during the winter since it is during that time that photoreduction is most important to the system. If photoreduction is the main mechanism causing diel cycling of Fe during the winter, as was determined in this study, covering the creek with sunlight inhibiting material during the winter should halt or alter the diel cycle in $\mathrm{Fe}$ species. 


\section{References}

Bourg, A.C.M., Kedziorek, M.A.M. and Crouzet, C., 2000. Seasonal Cycles of Dissolved $\mathrm{Cd}, \mathrm{Mn}$ and $\mathrm{Zn}$ in River Water Caused by Variations in $\mathrm{pH}$ Induced by Biological Activity. Aquatic Geochemistry, 6(4): 461-472.

Brick, C.M. and Moore, J.N., 1996. Diel Variation of Trace Metals in the Upper Clark Fork River, Montana. Environmental Science \& Technology, 30(6): 1953-1961.

Surface Mining Control and Reclamation Act, 1977. 30 U.S.C. 1201-1328 PL 95-87.

Christ, M., 2003. The State of the Creek, 2003, Friends of Deckers Creek, Dellslow, WV, $1-31$.

Christ, M., 2005. Watershed Based Plan for the Deckers Creek Watershed. 1-53.

Drever, J.I., 1997. The Geochemistry of Natural Waters: Surface and Groundwater Environments. Prentice Hall, New Jersey, 436 pp.

Faulkner, S.P., Hintze, P.E. and Ashby, S.L., 1999. Evaluation of Colorimetric Methods for Measuring Reduced (Ferrous) Iron. US Army Corps of Engineers, Water Quality Technical Note PD-02: 1-12.

Gammons, C.H., Nimick, D.A., Parker, S.R., Cleasby, T.E. and McCleskey, R.B., 2005a. Diel Behavior of Iron and Other Heavy Metals in a Mountain Stream with Acidic to Neutral pH: Fisher Creek, Montana, USA. Geochimica et Cosmochimica Acta, 69(10): 2505-2516.

Gammons, C.H., Wood, S.A. and Nimick, D.A., 2005b. Diel Behavior of Rare Earth Elements in a Mountain Stream with Acidic to Neutral pH. Geochimica et Cosmochimica Acta, 69(15): 3747-3759.

Helz, G.R., Zepp, R.G. and Crosby, D.G., 1994. Aquatic and Surface Photochemistry. Lewis Publishers, Ann Arbor, 576 pp.

Kachigan, S.K., 1982. Statistical Analysis: An Interdisciplinary Introduction to Univariate and Multivariate Methods. Radius Press, New York, 589 pp.

Konhauser, K., 2006. Introduction to Geomicrobiology. Blackwell Publishing, Malden, $440 \mathrm{pp}$.

Langmuir, D., 1997. Aqueous Environmental Geochemistry. Prentice Hall, New Jersey, $600 \mathrm{pp}$.

Liu, Z., Li, Q., Sun, H., Liao, C., Li, H., Wang, J. and Wu, K., 2006. Diurnal Variations of Hydrochemistry in a Travertine-depositing Stream at Baishuitai, Yunnan, SW China. Aquatic Geochemistry, 12: 103-121.

Lovley, D.R. and Phillips, E.J., 1987. Rapid Assay for Microbially Reducible Ferric Iron in Aquatic Sediments. Applied and Environmental Microbiology, 53: 1536-1541.

McKnight, D.M., Kimball, B.A. and Bencala, K.E., 1988. Iron Photoreduction and Oxidation in an Acidic Mountain Stream. Science, 240: 637-639.

McKnight, D.M., Kimball, B.A. and Runkell, R.L., 2001. pH Dependence of Iron Photoreduction in a Rocky Mountain Stream Affected by Acid Mine Drainage. Hydrological Processes, 15: 1979-1992.

Nimick, D., Gammons, C., Cleasby, T., Skaar, J.M. and Brick, C., 2003. Diel Cycles in Dissolved Metal Concentrations in Streams: Occurrence and Possible Causes. Water Resources Research, 39(9): 1-17. 
Nimick, D.A., Cleasby, T.E. and McCleskey, R.B., 2005. Seasonality of Diel Cycles of Dissolved Trace-metal Concentrations in a Rocky Mountain Stream. Environmental Geology, 47: 603-614.

Roberts, P.D. and Wilch, T.I., 2005. Diel Cycles in Stream Stage and Turbidity in a Small Midwestern Agricultural Stream: Implications for Water Quality Assessment, Geological Society of America, Salt Lake City, Poster Presentation 131-1.

Rose, A.W. and Cravotta, C.A.I., 1998. Geochemistry of Coal Mine Drainage. In: B.C. Brady, M.W. Smith and J Schueck (Editors), Coal Mine Drainage Prediction and Pollution Prevention in Pennsylvania. Pennsylvania Department of Environmental Protection, 1-22.

Stookey, L.L., 1970. Ferrozine - A New Spectrophotometric Reagent for Iron. Analytical Chemistry, 42(7): 779-781.

Vile, M.A. and Wieder, R.K., 1993. Alkalinity Generation by Fe(III) Reduction Versus Sulfate Reduction in Wetlands Constructed for Acid Mine Drainage Treatment. Water, Air, and Soil Pollution, 69: 425-441.

Wagner, W., Heyman, L., Gray, R., Belz, D., Lund, R., Cate, A. and Edgerton, C., 1970. Geology of the Pittsburgh Area, General Geology Report G59. Pennsylvania Geological Survey, Harrisburg, 145 pp.

Weber, K.A., Achenbach, L.A. and Coates, J.D., 2006. Microorganisms Pumping Iron: Anaerobic Microbial Iron Oxidation and Reduction. Nature Review Microbiology, 4: 752-764.

Wieder, R.K., 1994. Diel Changes in Iron(III)/Iron(II) in Effluent from Constructed Acid Mine Drainage Treatment Wetlands. Journal of Environmental Quality, 23: 730738. 
Appendix 
Table A-1: Data from Dillan Creek, March 30, 2007.

\begin{tabular}{ccccccc} 
Date / time & $\begin{array}{c}\text { Water temperature } \\
\left({ }^{\circ} \mathrm{C}\right)\end{array}$ & $\mathrm{pH}$ & $\begin{array}{c}3-30-2007 \\
\text { Conductivity } \\
(\mu \mathrm{S} / \mathrm{cm})\end{array}$ & $\begin{array}{c}\text { Dissolved Fe(ll) } \\
(\mathrm{mg} / \mathrm{L})\end{array}$ & $\begin{array}{c}\text { Dissolved Fe(lll) } \\
(\mathrm{mg} / \mathrm{L})\end{array}$ & $\begin{array}{c}\text { Dissolved Fe(tot) } \\
(\mathrm{mg} / \mathrm{L})\end{array}$ \\
\hline 3/30/2007 5:01 & 6.9 & 4.33 & 89.23 & 0.341 & 0.193 & 0.534 \\
$3 / 30 / 20076: 01$ & 6.55 & 4.35 & 88.1 & 0.354 & 0.168 & 0.521 \\
$3 / 30 / 20077: 01$ & 6.23 & 4.35 & 88.02 & 0.347 & 0.178 & 0.526 \\
$3 / 30 / 20078: 01$ & 6 & 4.35 & 88.52 & 0.394 & 0.162 & 0.556 \\
$3 / 30 / 20079: 01$ & 6 & 4.36 & 87.72 & 0.448 & 0.113 & 0.561 \\
$3 / 30 / 200710: 01$ & 6.41 & 4.34 & 89.4 & 0.505 & 0.078 & 0.583 \\
$3 / 30 / 200711: 01$ & 7.01 & 4.33 & 93.55 & 0.577 & 0.037 & 0.613 \\
$3 / 30 / 200712: 01$ & 7.74 & 4.33 & 94.91 & 0.611 & 0.033 & 0.644 \\
$3 / 30 / 200713: 01$ & 8.52 & 4.34 & 94.16 & 0.624 & -0.002 & 0.622 \\
$3 / 30 / 200714: 01$ & 9.39 & 4.36 & 95.3 & 0.620 & -0.011 & 0.609 \\
$3 / 30 / 200715: 01$ & 10.16 & 4.37 & 95.47 & 0.616 & 0.059 & 0.675 \\
$3 / 30 / 200716: 01$ & 10.93 & 4.37 & 97.03 & 0.595 & 0.014 & 0.609 \\
$3 / 30 / 200717: 01$ & 11.42 & 4.37 & 96.29 & 0.575 & 0.021 & 0.596 \\
$3 / 30 / 200718: 01$ & 11.52 & 4.32 & 101.98 & 0.568 & 0.045 & 0.613 \\
$3 / 30 / 200719: 01$ & 11.58 & 4.27 & 108.34 & 0.530 & 0.132 & 0.662 \\
$3 / 30 / 200720: 01$ & 11.57 & 4.2 & 115.15 & 0.493 & 0.178 & 0.670 \\
$3 / 30 / 200721: 01$ & 11.39 & 4.22 & 112.68 & 0.446 & 0.229 & 0.675 \\
$3 / 30 / 200722: 01$ & 11.06 & 4.24 & 110.17 & 0.456 & 0.188 & 0.644
\end{tabular}


Table A-2: Data from Dillan Creek, May 9, 2007.

\begin{tabular}{|c|c|c|c|c|c|c|}
\hline \multicolumn{7}{|c|}{ 5.9.2007 } \\
\hline Date / time & $\begin{array}{l}\text { Water temperature } \\
\left({ }^{\circ} \mathrm{C}\right)\end{array}$ & $\mathrm{pH}$ & $\begin{array}{l}\text { Conductivity } \\
(\mu \mathrm{S} / \mathrm{cm})\end{array}$ & $\begin{array}{c}\text { Dissolved Fe(II) } \\
(\mathrm{mg} / \mathrm{L})\end{array}$ & $\begin{array}{c}\text { Dissolved Fe(III) } \\
\text { (mg/L) }\end{array}$ & $\begin{array}{c}\text { Dissolved Fe(tot) } \\
(\mathrm{mg} / \mathrm{L})\end{array}$ \\
\hline $5,9 / 20074: 03$ & 13.37 & 4.35 & 81.25 & 0.931 & .0 .006 & 0.925 \\
\hline 5/9/2007 5:03 & 13.1 & 4.36 & 79.25 & 0.824 & 0.000 & 0.824 \\
\hline $5,9 / 20076: 03$ & 12.77 & 4.34 & 79.72 & 0.783 & 0.049 & 0.833 \\
\hline $5,9 / 2007$ 7:03 & 12.5 & 4.22 & 88.11 & 0.820 & 0.048 & 0.868 \\
\hline 5,9/2007 8:03 & 12.37 & 4.08 & 102.58 & 0.902 & 0.106 & 1.008 \\
\hline 5,9/2007 9:03 & 12.64 & 4.57 & 116.67 & 1.399 & -0.014 & 1.385 \\
\hline $5 / 9 / 200710: 03$ & 13.56 & 4.11 & 106.38 & 0.959 & 0.062 & 1.021 \\
\hline 5/9/2007 11:03 & 14.33 & 4.03 & 106.9 & 0.931 & 0.038 & 0.969 \\
\hline $5 / 9 / 200712: 03$ & 15.11 & 4.08 & 101.28 & 0.873 & 0.065 & 0.938 \\
\hline 5/9/2007 13:03 & 15.88 & 4.06 & 102.73 & 0.878 & 0.056 & 0.934 \\
\hline $5 / 9 / 200714: 03$ & 16.79 & 4.08 & 98.86 & 0.804 & 0.121 & 0.925 \\
\hline $5 / 9 / 2007$ 15:03 & 17.27 & 4.09 & 96.18 & 0.765 & 0.041 & 0.806 \\
\hline $5 / 9 / 200716: 03$ & 17.8 & 4.16 & 94.98 & 0.759 & 0.039 & 0.798 \\
\hline 5/9/2007 17:03 & 17.77 & 4.16 & 90.51 & 0.708 & 0.051 & 0.758 \\
\hline $5 / 9 / 200718: 03$ & 17.35 & 4.17 & 85.73 & 0.656 & 0.045 & 0.701 \\
\hline $5 / 9 / 2007$ 19:03 & 16.86 & 4.23 & 79.37 & 0.599 & 0.045 & 0.644 \\
\hline $5 / 9 / 200720: 03$ & 16.65 & 4.54 & 77.08 & 0.583 & 0.022 & 0.605 \\
\hline $5 / 9 / 200721: 03$ & 16.41 & 4.47 & 74.91 & 0.599 & 0.041 & 0.640 \\
\hline $5 / 9 / 200721: 58$ & 16.49 & 4.45 & 76.98 & 0.636 & 0.039 & 0.675 \\
\hline
\end{tabular}


Table A-3: Data from Dillan Creek, June 12, 2007.

\begin{tabular}{|c|c|c|c|c|c|c|}
\hline \multicolumn{7}{|c|}{$6 \cdot 12-2007$} \\
\hline Date / time & $\begin{array}{c}\text { Water temperature } \\
\left({ }^{\circ} \mathrm{C}\right)\end{array}$ & $\mathrm{pH}$ & $\begin{array}{l}\text { Conductivity } \\
(\mu \mathrm{S} / \mathrm{cm})\end{array}$ & $\begin{array}{c}\text { Dissolved Fe(II) } \\
(\mathrm{mg} / \mathrm{L})\end{array}$ & $\begin{array}{c}\text { Dissolved } \mathrm{Fe} \text { (III) } \\
(\mathrm{mg} / \mathrm{L})\end{array}$ & $\begin{array}{c}\text { Dissolved Fe(tot) } \\
(\mathrm{mg} / \mathrm{L})\end{array}$ \\
\hline $6 / 12 / 20074: 03$ & 15.51 & 4.12 & 305.27 & 4.582 & .0 .026 & 4.556 \\
\hline $6 / 12 / 20075: 03$ & 15.18 & 4.13 & 300.18 & 4.552 & 0.055 & 4.608 \\
\hline $6 / 12 / 20076: 03$ & 14.92 & 4.14 & 298.01 & 4.450 & .0 .079 & 4.370 \\
\hline $6 / 12 / 20077: 03$ & 14.82 & 4.14 & 294.73 & 4.489 & -0.158 & 4.332 \\
\hline $6 / 12 / 20078: 03$ & 14.92 & 4.14 & 296.14 & 4.522 & -0.095 & 4.428 \\
\hline $6 / 12 / 20079: 03$ & 15.64 & 4.14 & 304.16 & 4.579 & -0.119 & 4.460 \\
\hline $6 / 12 / 2007$ 10:03 & 17.8 & 4.12 & 317.95 & 4.380 & 0.009 & 4.389 \\
\hline 6/12/2007 11:03 & 21.02 & 4.09 & 339.67 & 3.976 & 0.092 & 4.068 \\
\hline $6 / 12 / 200712: 03$ & 23.63 & 4.05 & 364.72 & 3.658 & 0.115 & 3.773 \\
\hline $6 / 12 / 2007$ 13:03 & 24.41 & 4.01 & 382.98 & 3.453 & 0.179 & 3.632 \\
\hline $6 / 12 / 200714: 03$ & 25.65 & 3.97 & 405.04 & 3.367 & 0.240 & 3.606 \\
\hline $6 / 12 / 2007$ 15:03 & 27.06 & 3.93 & 424.99 & 3.195 & 0.309 & 3.504 \\
\hline $6 / 12 / 2007$ 16:03 & 25.97 & 3.9 & 421.08 & 3.158 & 0.262 & 3.420 \\
\hline $6 / 12 / 200717: 03$ & 25.35 & 3.9 & 414.44 & 3.125 & 0.263 & 3.388 \\
\hline $6 / 12 / 2007$ 18:03 & 24.32 & 3.91 & 393.11 & 3.251 & 0.253 & 3.504 \\
\hline $6 / 12 / 2007$ 19:03 & 22.71 & 3.93 & 369.73 & 3.357 & 0.134 & 3.491 \\
\hline $6 / 12 / 200720: 03$ & 20.98 & 3.96 & 351.48 & 3.387 & 0.104 & 3.491 \\
\hline $6 / 12 / 200721: 03$ & 19.88 & 3.96 & 336.95 & 3.635 & 0.113 & 3.748 \\
\hline $6 / 12 / 200721: 58$ & 19.33 & 3.98 & 323.65 & 3.764 & 0.054 & 3.818 \\
\hline
\end{tabular}


Table A-4: Data from Dillan Creek, August 13, 2007.

\begin{tabular}{|c|c|c|c|c|c|c|}
\hline \multicolumn{7}{|c|}{$8 \cdot 13-2007$} \\
\hline Date / time & $\begin{array}{l}\text { Water temperature } \\
\left({ }^{\circ} \mathrm{C}\right)\end{array}$ & $\mathrm{pH}$ & $\begin{array}{l}\text { Conductivity } \\
(\mu \mathrm{S} / \mathrm{cm})\end{array}$ & $\begin{array}{c}\text { Dissolved Fe(II) } \\
\text { (mg/L) }\end{array}$ & $\begin{array}{c}\text { Dissolved Fe(III) } \\
(\mathrm{mg} / \mathrm{L})\end{array}$ & $\begin{array}{c}\text { Dissolved Fe(tot) } \\
(\mathrm{mg} / \mathrm{L})\end{array}$ \\
\hline $8 / 13 / 20074: 02$ & 18.05 & 4.94 & 115.5 & 2.294 & -0.195 & 2.098 \\
\hline $8 / 13 / 20075: 02$ & 17.88 & 4.91 & 119.9 & 2.539 & .0 .523 & 2.017 \\
\hline $8 / 13 / 20076: 02$ & 17.69 & 4.93 & 117.99 & 2.292 & .0 .456 & 1.836 \\
\hline $8 / 13 / 2007$ 7:02 & 17.51 & 4.91 & 121.06 & 2.292 & -0.275 & 2.017 \\
\hline $8 / 13 / 20078: 02$ & 17.47 & 4.9 & 124.34 & 2.343 & .0 .552 & 1.791 \\
\hline $8 / 13 / 2007$ 9:02 & 17.64 & 4.88 & 123.97 & 2.181 & -0.165 & 2.017 \\
\hline $8 / 13 / 2007$ 10:02 & 18.28 & 4.86 & 125.91 & 2.114 & .0 .212 & 1.902 \\
\hline $8 / 13 / 200711: 02$ & 19.38 & 4.86 & 123.22 & 2.159 & -0.388 & 1.771 \\
\hline $8 / 13 / 200712: 02$ & 20.4 & 4.84 & 124.17 & 1.952 & .0 .288 & 1.664 \\
\hline 8/13/2007 13:02 & 21.33 & 4.67 & 151.02 & 1.942 & -0.245 & 1.697 \\
\hline $8 / 13 / 200714: 02$ & 22.1 & 4.58 & 163.49 & 1.948 & -0.214 & 1.734 \\
\hline $8 / 13 / 200715: 02$ & 22.86 & 4.55 & 161.49 & 1.862 & -0.329 & 1.533 \\
\hline $8 / 13 / 2007$ 16:02 & 23 & 4.52 & 165.49 & 1.854 & -0.050 & 1.803 \\
\hline $8 / 13 / 2007$ 17:02 & 22.66 & 4.53 & 160.6 & 1.803 & -0.098 & 1.705 \\
\hline $8 / 13 / 200718: 02$ & 21.98 & 4.56 & 150.86 & 1.733 & .0 .229 & 1.504 \\
\hline $8 / 13 / 2007$ 19:02 & 21.06 & 4.57 & 151.94 & 1.852 & -0.081 & 1.771 \\
\hline $8 / 13 / 200720: 02$ & 20.26 & 4.59 & 144.15 & 1.835 & .0 .089 & 1.746 \\
\hline $8 / 13 / 200721: 02$ & 19.68 & 4.56 & 149.7 & 1.952 & -0.140 & 1.812 \\
\hline $8 / 13 / 200721: 57$ & 19.17 & 4.71 & 122.99 & 2.048 & -0.368 & 1.681 \\
\hline
\end{tabular}


Table A-5: Data from location 1, Dillan Creek, August 15, 2007.

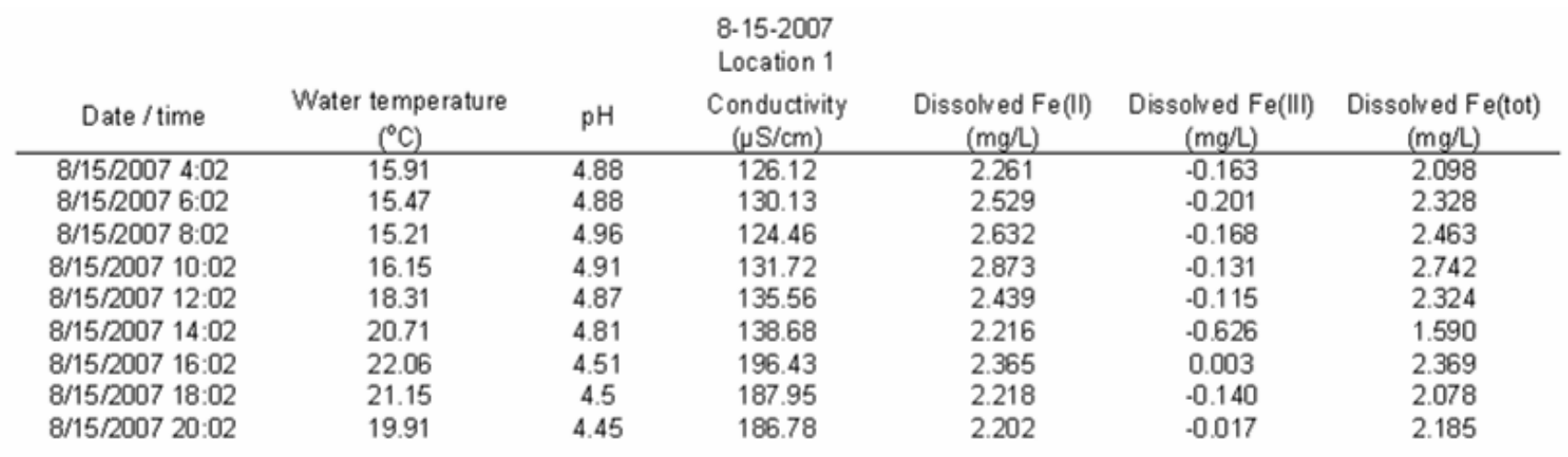


Table A-6: Data from location 2, Dillan Creek, August 15, 2007.

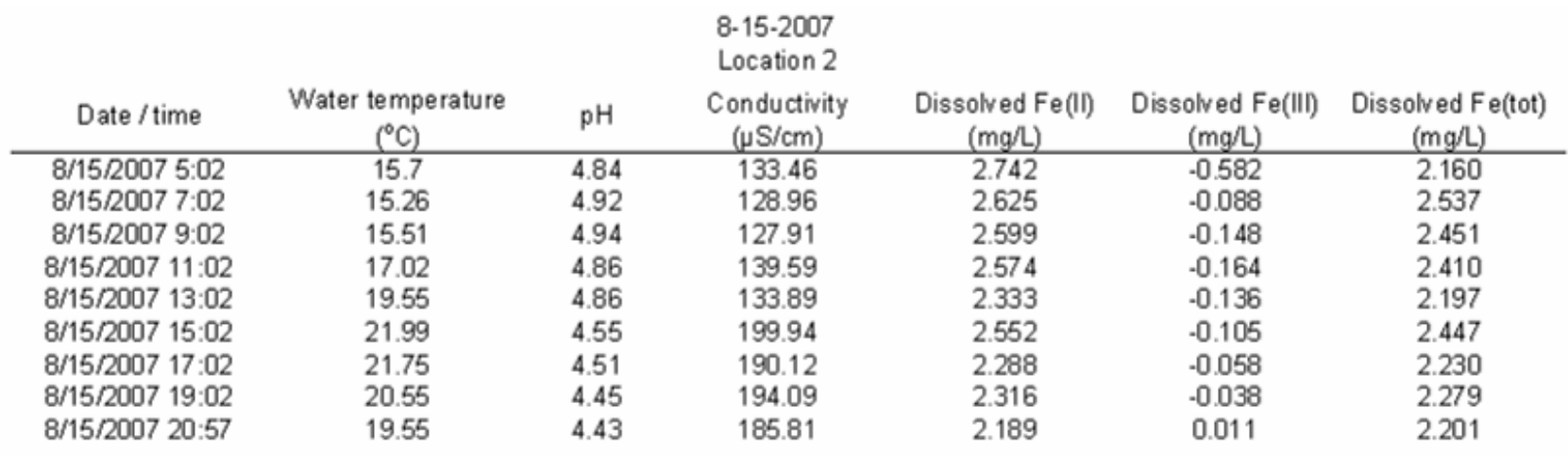


Table A-7: QC samples for Dillan Creek, March 30 and May 9, 2007.

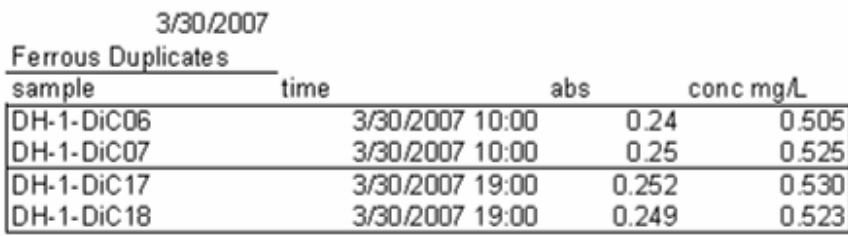

Ferrous Blank

\begin{tabular}{lllll|}
\hline Sample & time & \multicolumn{2}{c}{ abs } & \multicolumn{2}{c}{ conc mgh } \\
\hline $\mathrm{DH}$-1-DiC11 & $3 / 30 / 200713: 00$ & 0.018 & 0.051 \\
\hline
\end{tabular}

Total Iron Duplicates

\begin{tabular}{|c|c|c|c|}
\hline sample & time & abs & conc mg $\mathrm{L}$ \\
\hline DH-1-DiCO4 & $3 / 30 / 20078: 00$ & 0.147 & 0.556 \\
\hline DH-1-DiCO4 & $3 / 30 / 20078: 00$ & 0.149 & 0.565 \\
\hline DH-1-DiC06 & $3 / 30 / 200710: 00$ & 0.153 & 0.583 \\
\hline $\mathrm{DH}-1-\mathrm{DiCO} 7$ & $3 / 30 / 200710: 00$ & 0.157 & 0.600 \\
\hline DH-1-DiC17 & $3 / 30 / 200719: 00$ & 0.171 & 0.662 \\
\hline DH-1-DiC 18 & $3 / 30 / 2007$ 19:00 & 0.162 & 0.622 \\
\hline DH-1-DiC19 & $3 / 30 / 200720: 00$ & 0.173 & 0.670 \\
\hline $\mathrm{DH}-1-\mathrm{DiC} 19$ & $3 / 30 / 200720: 00$ & 0.174 & 0.675 \\
\hline
\end{tabular}

Field Sample Blank
\begin{tabular}{lllll} 
& & & \\
sample & time & abs & \multicolumn{2}{c}{ conc mgh } \\
\hline DH-1-DiC11 & $3 / 30 / 2007$ & $13: 00$ & 0.028 & 0.034 \\
\hline
\end{tabular}

\begin{tabular}{|c|c|c|c|c|}
\hline Lab Blank & & & & \\
\hline sample & time & abs & & conc mg $\mathrm{L}$ \\
\hline blank & & & 0.016 & -0.018 \\
\hline
\end{tabular}

$\begin{gathered}5 / 9 / 2007 \\
\text { Ferrous Duplicates }\end{gathered}$
\begin{tabular}{llrrr|} 
sample & & & & \\
time & & abs & \multicolumn{2}{c}{ conc mg/L } \\
\hline DH-2-DiC06 & $5 / 9 / 20079: 00$ & 0.677 & 1.399 \\
DH-2-DiC07 & $5 / 9 / 20079: 00$ & 0.677 & 1.399 \\
\hline DH-2-DiC16 & $5 / 9 / 200717: 00$ & 0.339 & 0.708 \\
DH-2-DiC17 & $5 / 9 / 200717: 00$ & 0.353 & 0.736 \\
\hline
\end{tabular}

Ferrous Blank

\begin{tabular}{|c|c|c|c|c|}
\hline sample & time & & & conc mg/L \\
\hline DH-2-DiC15 & & $5 / 9 / 200716: 00$ & 0.012 & 0.038 \\
\hline \multicolumn{5}{|c|}{ Total Iron Duplicates } \\
\hline sample & time & & & conc mg/L \\
\hline DH-2-DiC05 & & $5 / 9 / 20078: 00$ & 0.25 & 1.008 \\
\hline DH-2-DiC05 & & $5 / 9 / 20078.00$ & 0.248 & 0.999 \\
\hline DH-2-DiC06 & & $5 / 9 / 20079: 00$ & 0.336 & 1.385 \\
\hline DH-2-DiCO7 & & $5 / 9 / 20079: 00$ & 0.32 & 1.315 \\
\hline DH-2-DiC16 & & $5 / 9 / 200717: 00$ & 0.193 & 0.758 \\
\hline DH-2-DiC17 & & 5/9/2007 17:00 & 0.196 & 0.771 \\
\hline
\end{tabular}

Field Sample Blank

\begin{tabular}{lllll|}
\hline sample & time & \multicolumn{2}{c}{ abs } & \multicolumn{2}{c}{ conc mg/L } \\
\hline DH-2-DiC15 & $5 / 9 / 2007$ & $16: 00$ & 0.021 & 0.004 \\
\hline
\end{tabular}


Table A-8: QC samples for Dillan Creek, June 12 and August 13, 2007.

$\begin{gathered}6 / 12 / 2007 \\
\text { Ferrous Duplicates }\end{gathered}$
\begin{tabular}{lrrrr|}
\hline sample & & & \multicolumn{2}{c}{ conc mg/. } \\
\hline DH-3-DiC05 & $6 / 12 / 20078: 00$ & 1.376 & 4.522 \\
DH-3-DiC06 & $6 / 12 / 20078: 00$ & 1.379 & 4.532 \\
\hline DH-3-DiC15 & $6 / 12 / 200716: 00$ & 0.964 & 3.158 \\
DH-3-Dic16 & $6 / 12 / 200716: 00$ & 0.953 & 3.122 \\
\hline
\end{tabular}

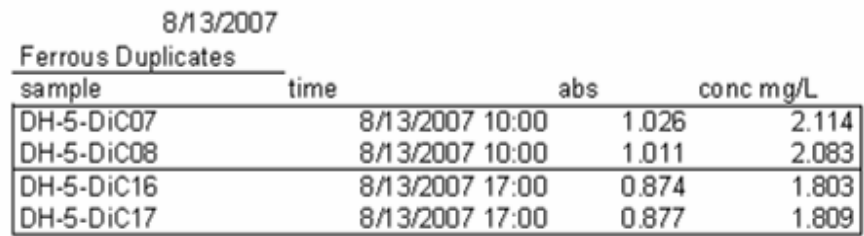

Ferrous Blank

\begin{tabular}{|lrrr|}
\hline sample & time & abs & \multicolumn{2}{c}{ conc mg/ } \\
\hline DH.3-DiC10 & $6 / 12 / 200711: 00$ & 0.01 & -0.001 \\
\hline
\end{tabular}

Total Iron Duplicates

\begin{tabular}{|lrrr|}
\hline sample & time & abs & conc mg/ \\
\hline DH-3-DiC05 & $6 / 12 / 20078: 00$ & 0.716 & 4.428 \\
DH-3-DiC06 & $6 / 12 / 20078: 00$ & 0.697 & 4.306 \\
\hline DH-3-DiC08 & $6 / 12 / 200710: 00$ & 0.71 & 4.389 \\
DH-3-DiC08 & $6 / 12 / 200710: 00$ & 0.723 & 4.473 \\
\hline DH-3-DiC15 & $6 / 12 / 200716: 00$ & 0.559 & 3.420 \\
DH-3-DiC16 & $6 / 12 / 200716: 00$ & 0.563 & 3.446 \\
\hline
\end{tabular}

Field Sample Blank

\begin{tabular}{|llll|}
\hline sample & time & abs & conc mg/ \\
\hline DH-3-DiC10 & $6 / 12 / 200711: 00$ & 0.012 & -0.090 \\
\hline
\end{tabular}

Ferrous Blank

sample time abs conc mg/L

\begin{tabular}{|llll|}
\hline DH-5-DiC13 & \multicolumn{2}{c}{ abs } & \multicolumn{2}{c}{ conc mg/L } \\
\hline
\end{tabular}

Total Iron Duplicates

\begin{tabular}{|llrr|}
\hline sample & time & abs & conc mg/L \\
\hline DH-5-DiC07 & $8 / 13 / 200710: 00$ & 0.488 & 1.902 \\
DH-5-DiC08 & $8 / 13 / 200710: 00$ & 0.483 & 1.881 \\
\hline DH-5-DiC14 & $8 / 13 / 200715: 00$ & 0.398 & 1.533 \\
DH-5-DiC14 & $8 / 13 / 200715: 00$ & 0.393 & 1.512 \\
\hline DH-5-DiC16 & $8 / 13 / 200717: 00$ & 0.44 & 1.705 \\
DH-5-DiC17 & $8 / 13 / 200717: 00$ & 0.439 & 1.701 \\
\hline
\end{tabular}

Field Sample Blank

\begin{tabular}{|c|c|c|c|}
\hline sample & time & abs & conc mg/L \\
\hline DH-5-DiC13 & $8 / 14 / 200714: 00$ & 0.019 & -0.020 \\
\hline \multicolumn{4}{|l|}{ Lab Blank } \\
\hline blank & - & 0.014 & -0.041 \\
\hline
\end{tabular}


Table A-9: QC samples for Dillan Creek, August 15, 2007.

$\begin{gathered}8 / 15 / 2007 \\
\text { Ferrous Duplicates }\end{gathered}$
\begin{tabular}{lllrr|} 
sample & & & & \\
\hline DH-6-DiC08 & & abs & \multicolumn{2}{c|}{ conc mg/ } \\
\hline DH-6-DiC09 & $8 / 15 / 200711: 00$ & 1.251 & 2.574 \\
\hline DH-6-DiC13 & $8 / 15 / 200711: 00$ & 1.251 & 2.574 \\
DH-6-DiC14 & $8 / 15 / 200715: 00$ & 1.24 & 2.552 \\
\hline
\end{tabular}

Ferrous Blank

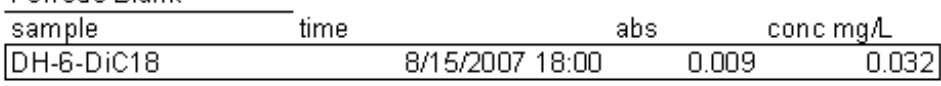

Total Iron Duplicates

\begin{tabular}{|llll|}
\hline sample & time & & \multicolumn{2}{c}{ abs } & \multicolumn{2}{c}{ conc mg/L } \\
\hline DH-6-DiC09 & $8 / 15 / 200711: 00$ & 0.357 & 1.365 \\
DH-6-DiC09 & $8 / 15 / 200711: 00$ & 0.355 & 1.357 \\
\hline DH-6-DiC12 & $8 / 15 / 200714: 00$ & 0.412 & 1.590 \\
DH-6-DiC12 & $8 / 15 / 200714: 00$ & 0.408 & 1.574 \\
\hline DH-6-DiC13 & $8 / 15 / 200715: 00$ & 0.621 & 2.447 \\
DH-6-DiC14 & $8 / 15 / 200715: 00$ & 0.616 & 2.426 \\
\hline
\end{tabular}

Field Sample Blank

sample

time

\begin{tabular}{llr} 
& abs & \multicolumn{2}{r}{ conc mg/L } \\
$8 / 15 / 200718: 00$ & 0.016 & -0.032
\end{tabular}

DH-6-DiC18

Lab Blank

blank 0.014 $-0.041$ 
Table A-10: Factor analysis for variables from March 30, 2007.

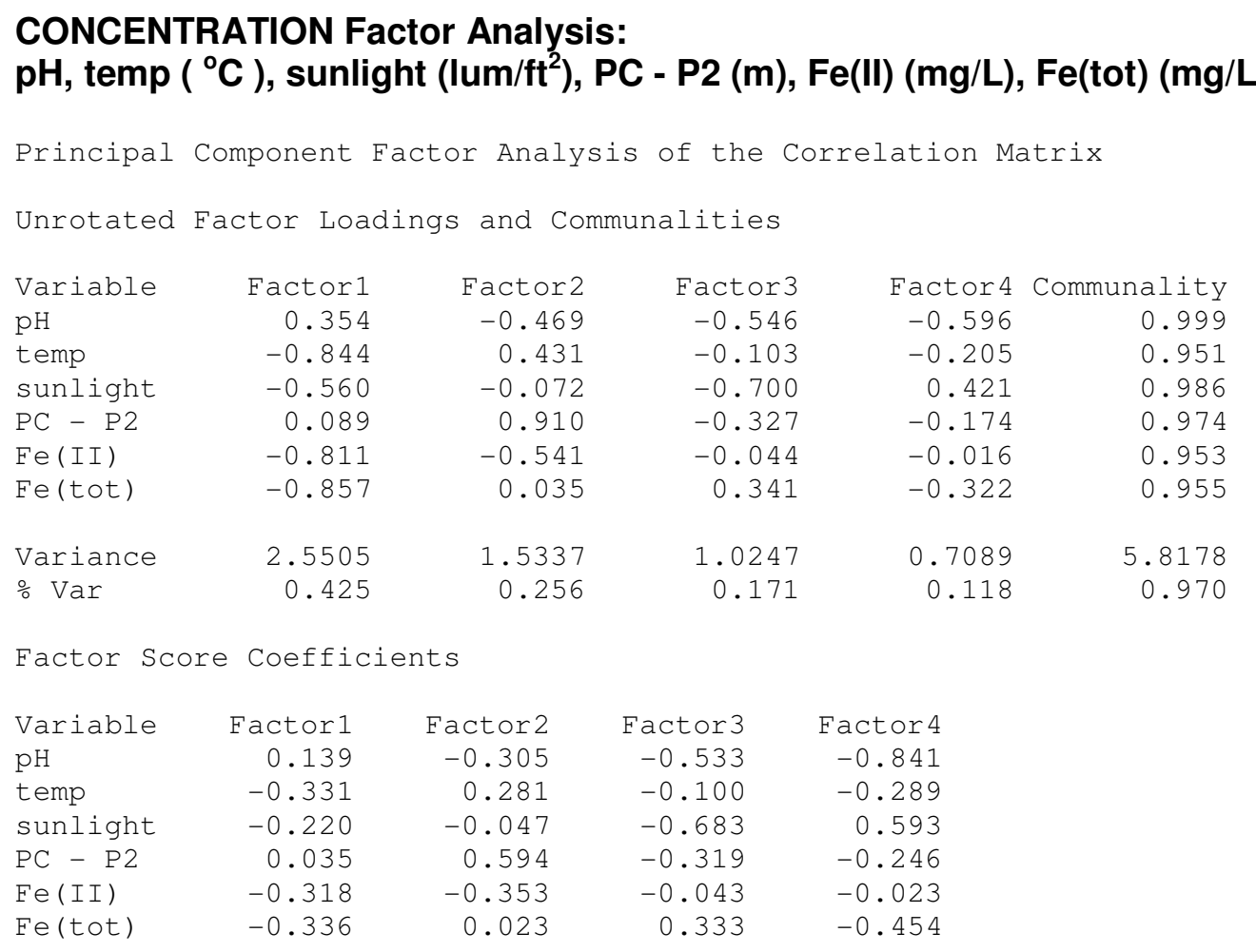

\section{FRACTION OF MEAN Factor Analysis: \\ $\mathrm{pH}$, temp ( ${ }^{\circ} \mathrm{C}$ ), sunlight (lum/ft ${ }^{2}$ ), PC - P2 (m), Fe(II) (mg/L), Fe(tot) (mg/L)}

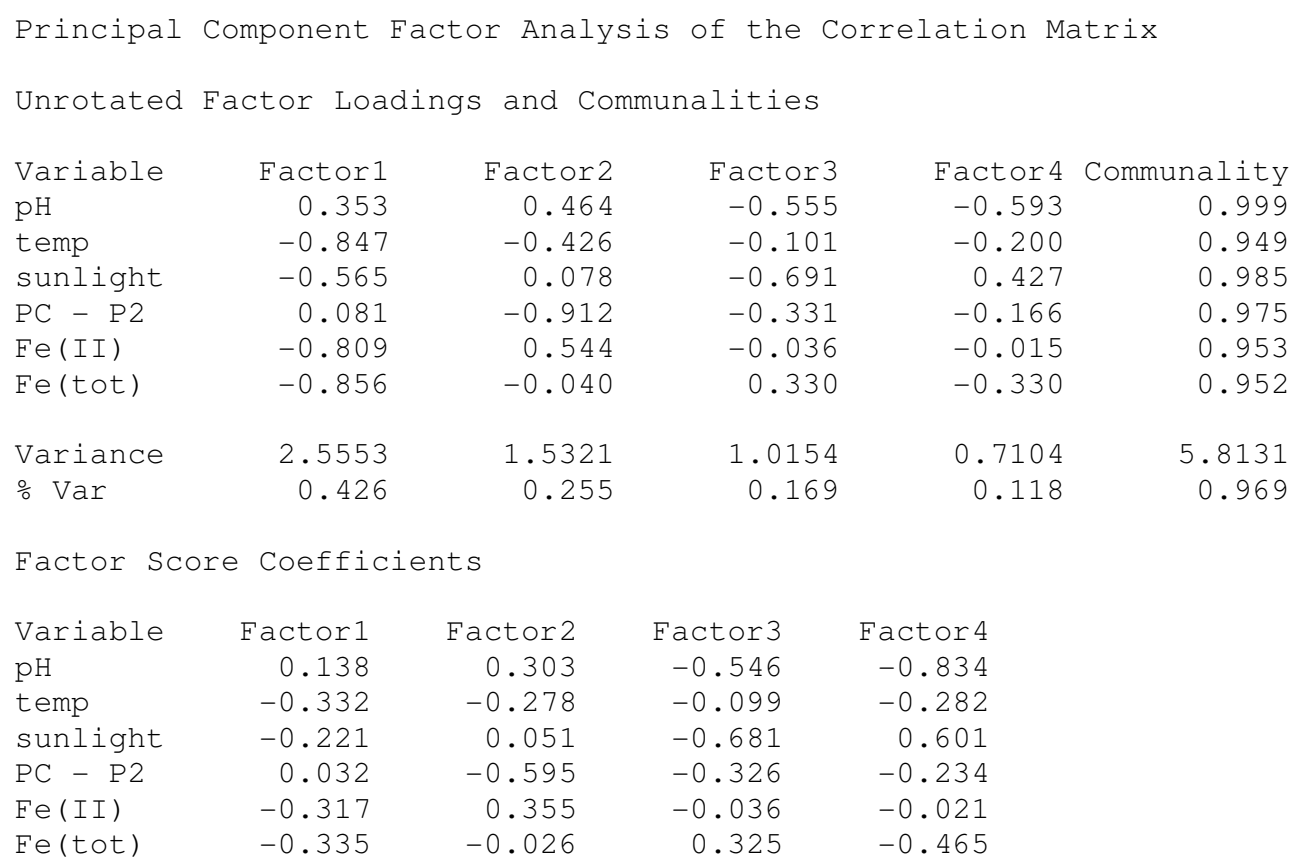


Table A-11: Factor analysis for variables from May 9, 2007.

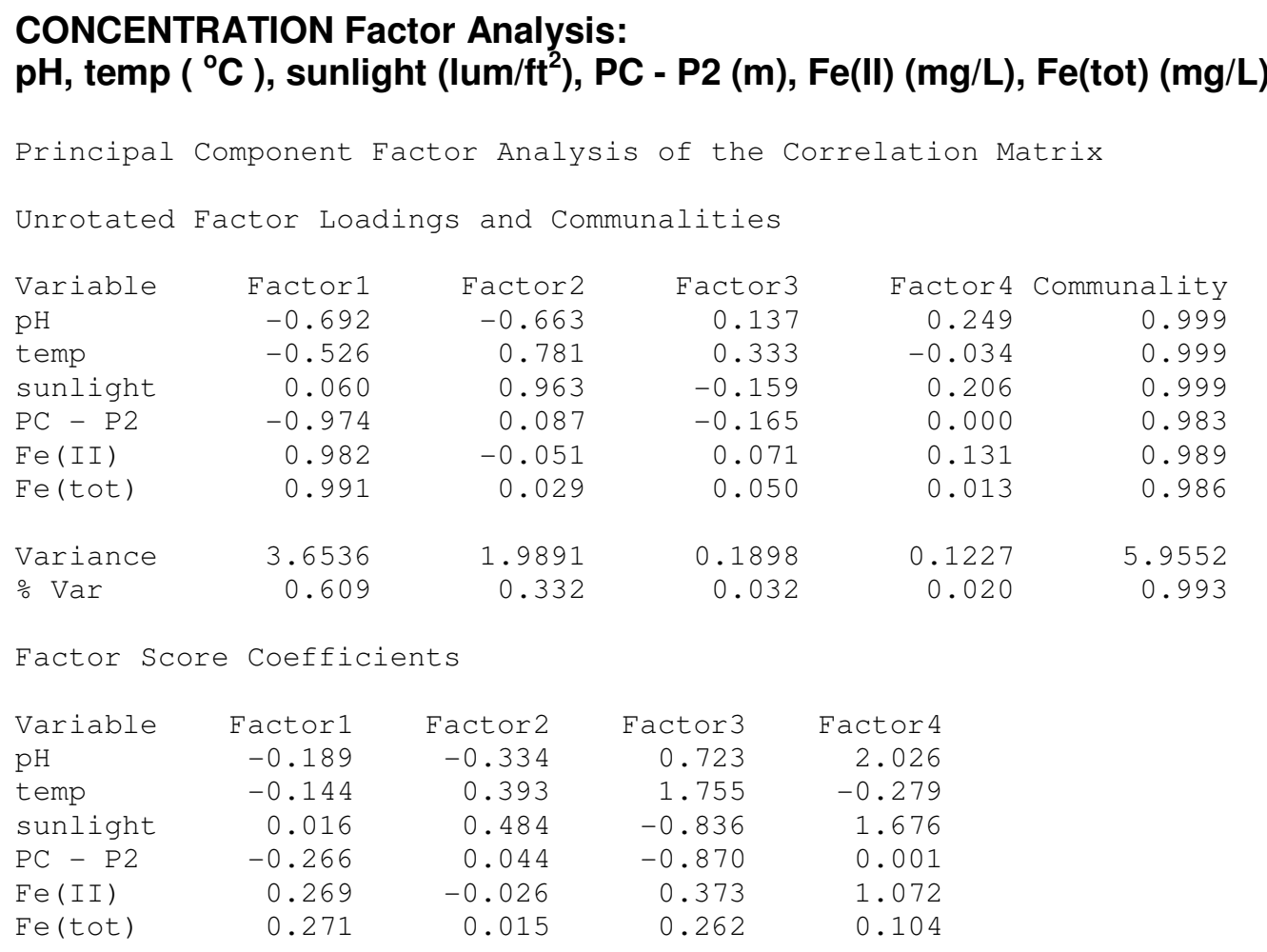

FRACTION OF MEAN Factor Analysis:

$\mathrm{pH}$, temp ( ${ }^{\circ} \mathrm{C}$ ), sunlight (lum/ft $\left.{ }^{2}\right), \mathrm{PC}$ - P2 (m), Fe(II) (mg/L), Fe(tot) (mg/L)

\begin{tabular}{|c|c|c|c|c|c|}
\hline \multicolumn{6}{|l|}{ Unrotated } \\
\hline Variable & Factor 1 & Factor 2 & Factor3 & Factor 4 & Communality \\
\hline $\mathrm{pH}$ & 0.692 & 0.663 & -0.139 & 0.249 & 0.999 \\
\hline temp & 0.525 & -0.782 & -0.334 & -0.035 & 0.999 \\
\hline sunlight & -0.061 & -0.963 & 0.158 & 0.206 & 0.999 \\
\hline $\mathrm{PC}-\mathrm{P} 2$ & 0.974 & -0.088 & 0.164 & 0.002 & 0.982 \\
\hline $\mathrm{Fe}(\mathrm{I})$ & -0.982 & 0.058 & -0.071 & 0.126 & 0.989 \\
\hline $\mathrm{Fe}(\mathrm{tot})$ & -0.991 & -0.035 & -0.052 & 0.019 & 0.987 \\
\hline Variance & 3.6540 & 1.9902 & 0.1903 & 0.1218 & 5.9562 \\
\hline \%Var & 0.609 & 0.332 & 0.032 & 0.020 & 0.993 \\
\hline
\end{tabular}

Factor Score Coefficients

$\begin{array}{lrrrr}\text { Variable } & \text { Factorl } & \text { Factor2 } & \text { Factor3 } & \text { Factor4 } \\ \text { pH } & 0.189 & 0.333 & -0.729 & 2.042 \\ \text { temp } & 0.144 & -0.393 & -1.754 & -0.285 \\ \text { sunlight } & -0.017 & -0.484 & 0.831 & 1.692 \\ \text { PC - P2 } & 0.266 & -0.044 & 0.862 & 0.014 \\ \text { Fe (II) } & -0.269 & 0.029 & -0.375 & 1.035 \\ \text { Fe(tot) } & -0.271 & -0.018 & -0.271 & 0.159\end{array}$


Table A-12: Factor analysis for variables from June 12, 2007.

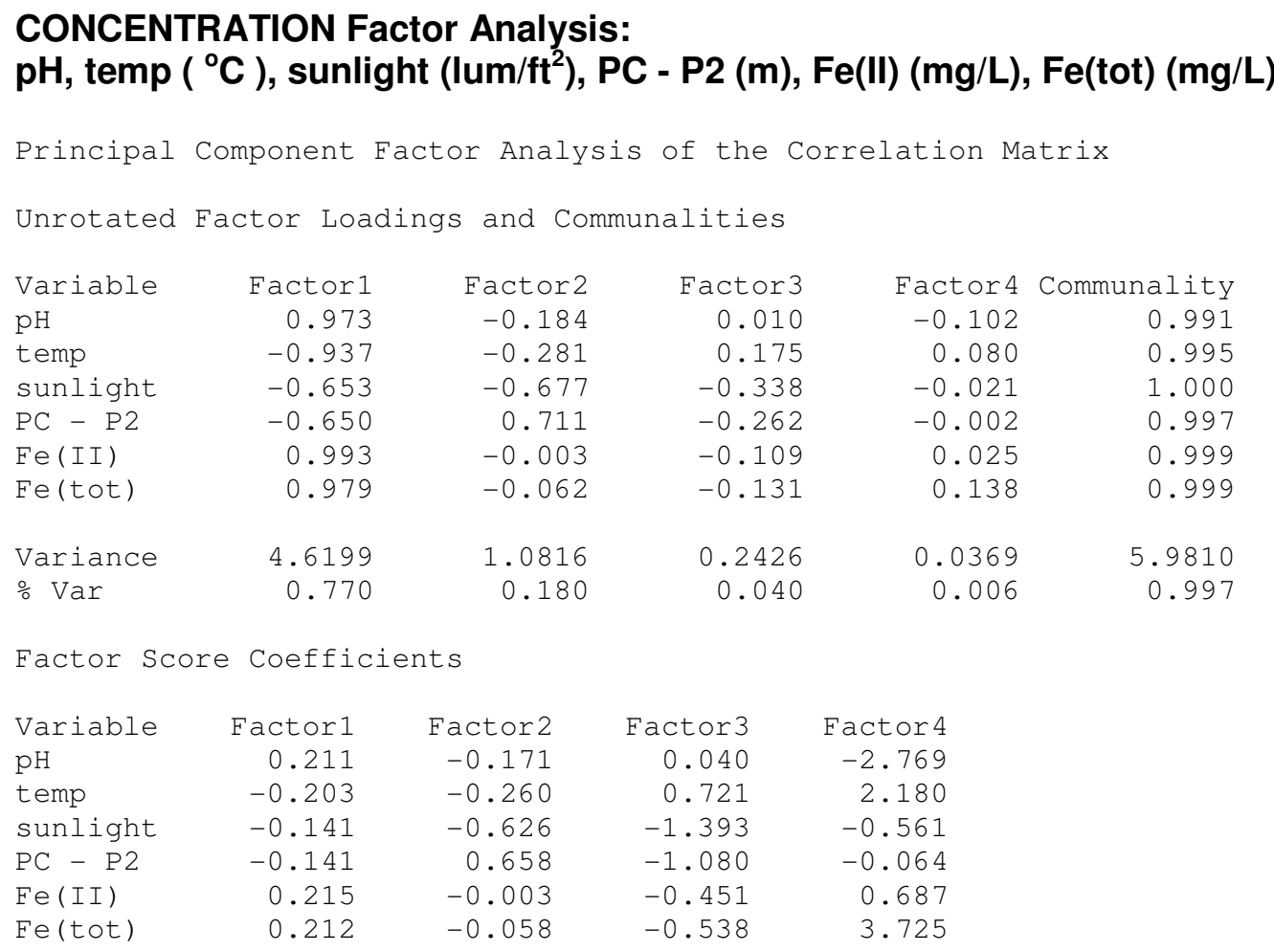

FRACTION OF MEAN Factor Analysis:

$\mathrm{pH}$, temp ( ${ }^{\circ} \mathrm{C}$ ), sunlight (lum/ft $\left.{ }^{2}\right), \mathrm{PC}$ - P2 (m), Fe(II) (mg/L), Fe(tot) (mg/L)

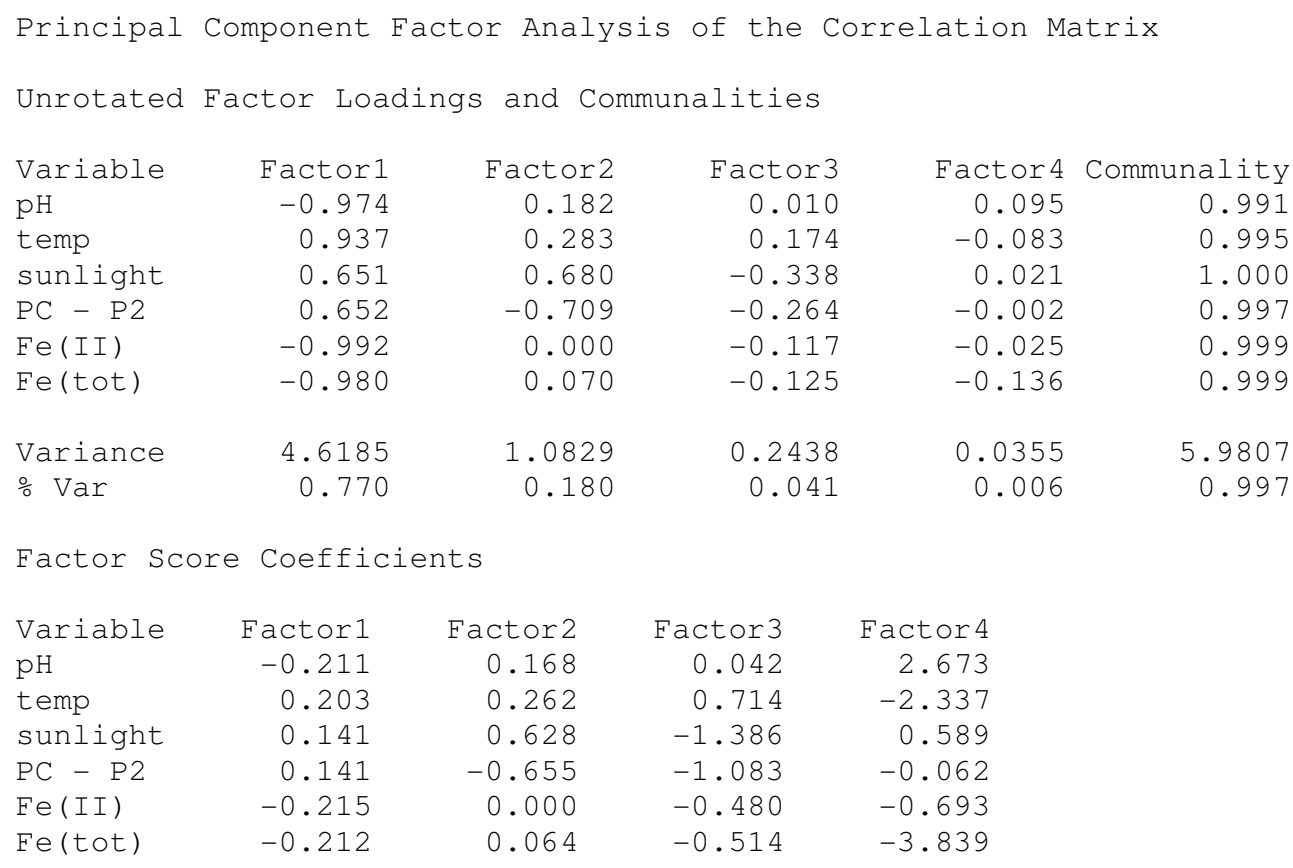


Table A-13: Factor analysis for variables from August 13, 2007.

\begin{tabular}{|c|c|c|c|c|}
\hline \multicolumn{5}{|c|}{$\begin{array}{l}\text { CONCENTRATION Factor Analysis: } \\
\left.\left.\text { pH, temp ( }{ }^{\circ} \mathrm{C}\right) \text {, sunlight (lum/ft }{ }^{2}\right), \text { PC - P2 (m), Fe(II) (m }\end{array}$} \\
\hline fincipal & I Component & cor Analy & is of the Co & orrelati \\
\hline \multicolumn{5}{|c|}{ Unrotated Factor Loadings and Communalities } \\
\hline Variable & Factor 1 & Factor 2 & Factor 3 & Fact \\
\hline $\mathrm{pH}$ & 0.923 & 0.270 & -0.177 & -0 \\
\hline temp & -0.943 & 0.115 & 0.197 & \\
\hline sunlight & -0.702 & 0.678 & 0.136 & -0 \\
\hline $\mathrm{PC}-\mathrm{P} 2$ & -0.882 & -0.373 & -0.038 & -0 \\
\hline $\mathrm{Fe}(\mathrm{II})$ & 0.955 & 0.139 & -0.019 & \\
\hline $\mathrm{Fe}(\mathrm{tot})$ & 0.838 & -0.152 & 0.512 & -0 \\
\hline Variance & 4.6249 & 0.7279 & 0.3528 & 0 \\
\hline \% Var & 0.771 & 0.121 & 0.059 & \\
\hline \multicolumn{5}{|c|}{ Factor Score Coefficients } \\
\hline Variable & Factor1 & Factor 2 & Factor3 & Factor 4 \\
\hline $\mathrm{pH}$ & 0.200 & 0.372 & -0.502 & -0.842 \\
\hline temp & -0.204 & 0.157 & 0.558 & 1.175 \\
\hline sunlight & -0.152 & 0.932 & 0.384 & -0.864 \\
\hline $\mathrm{PC}-\mathrm{P} 2$ & -0.191 & -0.512 & -0.108 & -1.351 \\
\hline $\operatorname{Fe}(I I)$ & 0.206 & 0.191 & -0.055 & 0.611 \\
\hline $\mathrm{Fe}$ (tot) & 0.181 & -0.209 & 1.452 & -0.591 \\
\hline
\end{tabular}

\section{FRACTION OF MEAN Factor Analysis:}

\section{$\mathrm{pH}$, temp $\left({ }^{\circ} \mathrm{C}\right)$, sunlight (lum/ft $\left.{ }^{2}\right), \mathrm{PC}-\mathrm{P2}(\mathrm{m}), \mathrm{Fe}(\mathrm{II})(\mathrm{mg} / \mathrm{L}), \mathrm{Fe}(\mathrm{tot})(\mathrm{mg} / \mathrm{L})$}

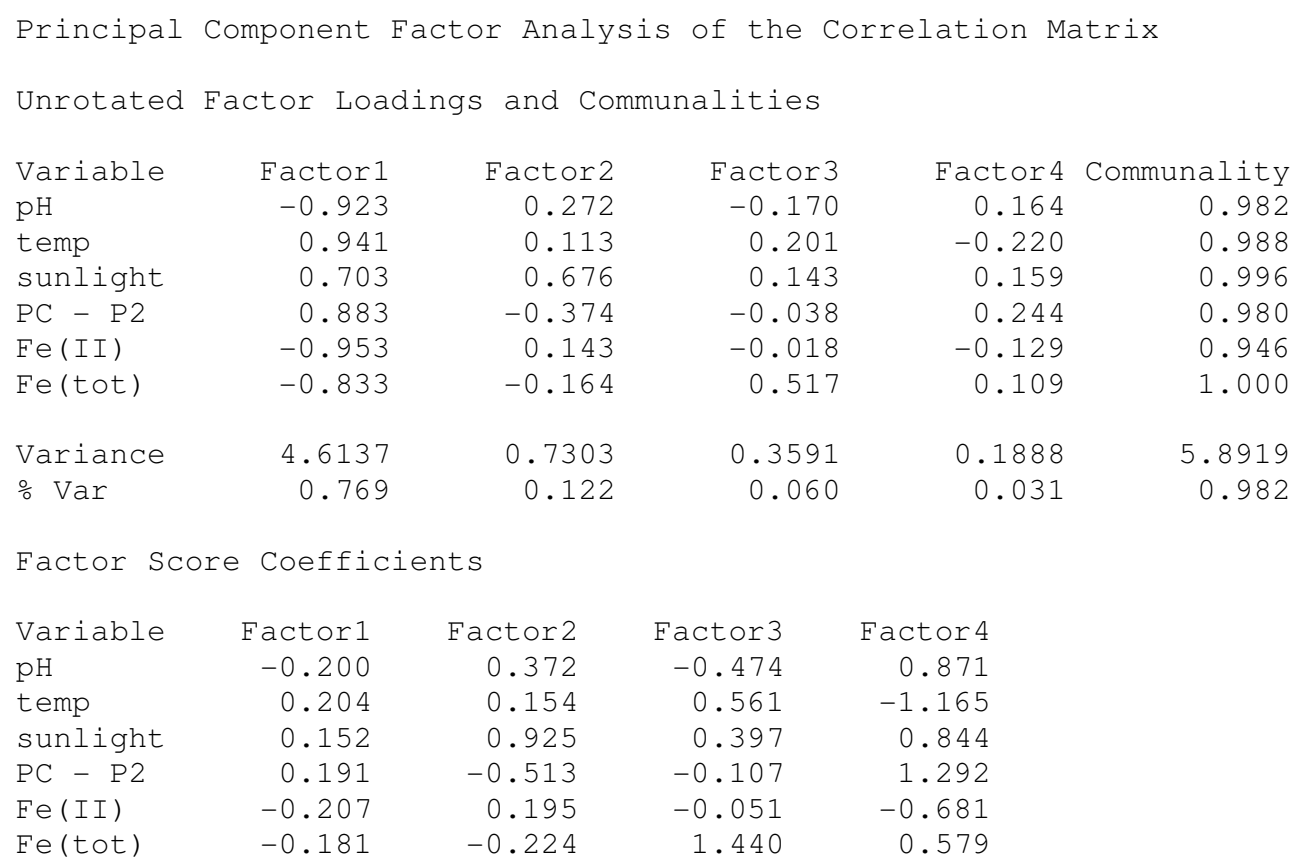


Table A-14: Redox iron reactions and log Ksp values.

Reaction pair

$$
\begin{gathered}
\mathrm{Fe}^{3+}-\mathrm{Fe}(\mathrm{OH})^{2+} \\
\mathrm{Fe}(\mathrm{OH})^{2+}-\mathrm{Fe}(\mathrm{OH})_{2}^{+} \\
\mathrm{Fe}(\mathrm{OH})_{2}^{+}-\mathrm{Fe}(\mathrm{OH})_{3} \text { amorphous } \\
\mathrm{Fe}^{2+}-\mathrm{Fe}^{3+} \\
\mathrm{Fe}^{2+}-\mathrm{Fe}(\mathrm{OH})^{2+} \\
\mathrm{Fe}^{2+}-\mathrm{Fe}(\mathrm{OH})_{2}^{+} \\
\mathrm{Fe}^{2+}-\mathrm{Fe}(\mathrm{OH})_{3} \text { amorphous } \\
\mathrm{Fe}{ }^{2+}-\mathrm{Fe}(\mathrm{OH})_{2} \\
\mathrm{Fe}(\mathrm{OH})_{2}-\mathrm{Fe}(\mathrm{OH})_{3} \text { amorphous }
\end{gathered}
$$

Reaction

$\log \mathrm{Ksp}$ 